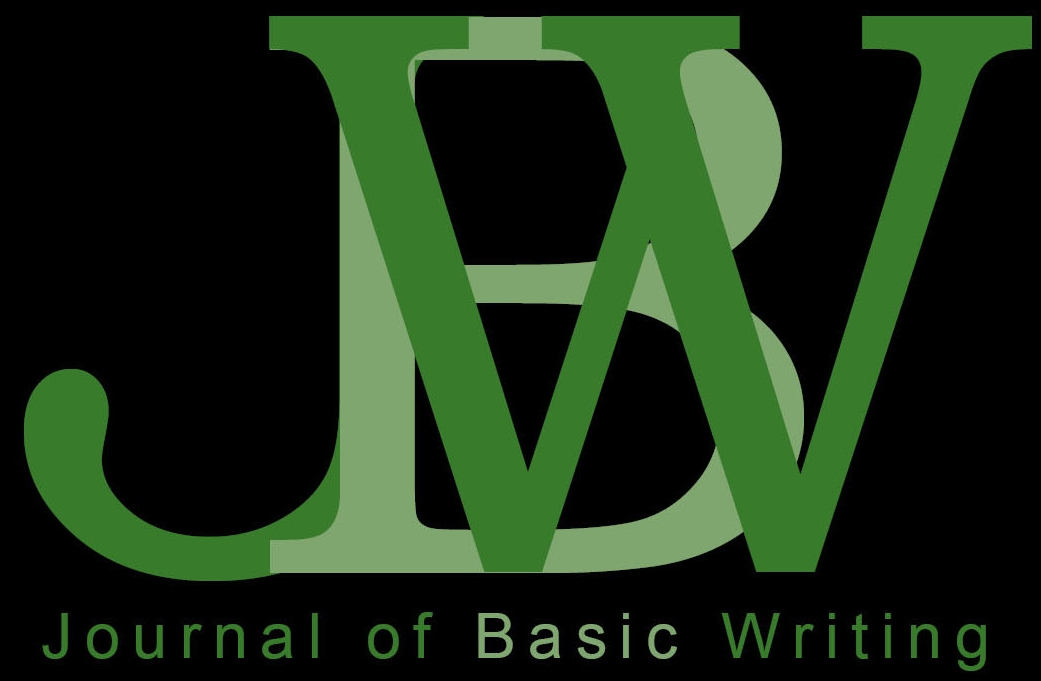

Minority-Serving Institutions, Race-Conscious "Dwelling," and Possible Futures for Basic Writing at Predominantly White Institutions

Steve Lamos

Troubling Discourse: Basic Writing and Computed-Mediated Technologies Leigh Jonaitis

Interrogating Texts: From Deferent to Efferent and Aesthetic Reading Practices

Cheryl Hogue Smith

Steep Houses in Basic Writing: Advocating for Latino Immigrants in a North Georgia Two-Year College Spencer Salas

Comedy Stages, Poets Projects, Sports Columns, and Kinesiology 341: Illuminating the Importance of Basic Writers' Self-Sponsored Literacies

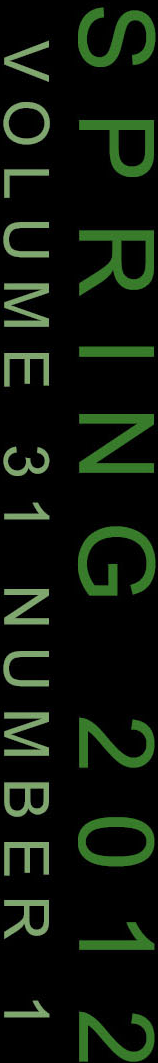
Kevin Roozen 



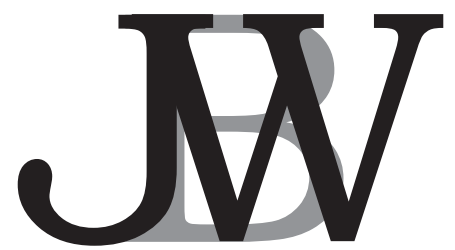

Journal of Basic Writing

VOLUME 3I NUMBER I SPRING 2012

The Journal of Basic Writing publishes articles of theory, research, and teaching practices related to basic writing. Articles are refereed by members of the Editorial Board (see overleaf) and the Editors.

\section{Hope Parisi and Cheryl C. Smith} Editors

Ann Del Principe

Associate Editor

\section{Rebecca Mlynarczyk and Bonne August} Consulting Editors

Angela J. Francis and Dominique Zino Editorial Assistants

\section{Maria Scordaras}

Business Manager

The Journal of Basic Writing is published twice a year, in the spring and fall, with support from the City University of New York, Office of Academic Affairs. We welcome unsolicited manuscripts and ask authors to consult the detailed "Call for Articles" in this issue. Subscriptions for individuals are \$20.00 for one year and \$35.00 for two years; subscriptions for institutions are $\$ 30$. oo for one year and $\$ 45.00$ for two years. Foreign postage is $\$$ Io.oo extra per year. For subscription inquiries or updates, contact:

Journal of Basic Writing

P.O. Box 465

Hanover, PA I733I

Phone: (7I7) 632-3535

Fax: (7I7) 633-8920

e-mail:pubsvc@tsp.sheridan.com

Published by the City University of New York since 1975

Cover and logo design by Kimon Frank

Copyright $\left(C_{2} 2\right.$ II by the Journal of Basic Writing 


\section{JOURNAL OF BASIC WRITING}

\section{EDITORIAL BOARD}

Linda Adler-Kassner

University of California, Santa Barbara

Hannah Ashley

West Chester University

David Bartholomae

University of Pittsburgh

Sarah Benesch

College of Staten Island, CUNY

Susan Naomi Bernstein

Independent Scholar

Patricia Bizzell

College of the Holy Cross

Lynn Z. Bloom

University of Connecticut, Storrs

Gay Brookes

Borough of Manhattan Comm. College, CUNY

Richard Courage

Westchester Community College, SUNY

Martha Clark Cummings

Kingsborough Community College, CUNY

Suellynn Duffey

Georgia Southern University

Chitralekha Duttagupta

Utah Valley University

Gregory Glau

Northern Arizona University

Laura Gray-Rosendale

Northern Arizona University

Karen L. Greenberg

Hunter College, CUNY

Kim Gunter

Appalachian State University

Susanmarie Harrington

University of Vermont

Donald J. Kraemer

California Polytechnic State University

Patricia O. Laurence

City College, CUNY

Andrea A. Lunsford

Stanford University

Jane Maher

Nassau Community College, SUNY

Paul Kei Matsuda

Arizona State University

Mark McBeth

John Jay College and Graduate Center, CUNY
Geraldine McNenny

Chapman University

Susan Miller

University of Utah

Deborah Mutnick

Long Island University

Nathaniel Norment, Jr.

Temple University

George Otte

Graduate Center, CUNY

Thomas Peele

Long Island University

Wendy Ryden

Long Island University

Yolanda Sealey-Ruiz

Teachers College, Columbia University

Charles I. Schuster

University of Wisconsin, Milwaukee

Tony Silva

Purdue University

Trudy Smoke

Hunter College, CUNY

Linda Stine

Lincoln University

Lynn Quitman Troyka

Queensborough Comm. College, CUNY, ret.

Evelyn E. Webb

Miss. State Board for Comm. and Junior Colleges

Harvey S. Wiener

LaGuardia Community College, Emeritus 


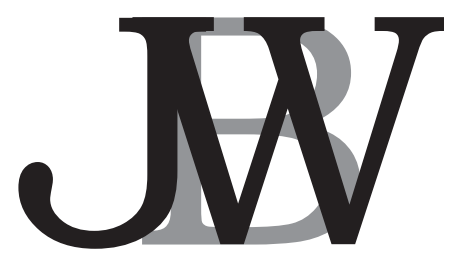

Journal of Basic Writing

VOLUME $3 \mathbf{I}$

NUMBER I

Spring 2012

Editors' Column

Minority-Serving Institutions, Race-Conscious

4

'Dwelling,' and Possible Futures for Basic Writing

at Predominantly White Institutions"

\section{Steve Lamos}

Troubling Discourse: Basic Writing and

Computed-Mediated Technologies

\section{Leigh Jonaitis}

Interrogating Texts: From Deferent to Efferent

and Aesthetic Reading Practices

\section{Cheryl Hogue Smith}

Steep Houses in Basic Writing: Advocating for

Latino Immigrants in a North Georgia Two-Year College

\section{Spencer Salas}

Comedy Stages, Poets Projects, Sports Columns, and Kinesiology 34I: Illuminating the Importance of Basic Writers' Self-Sponsored Literacies

\section{Kevin Roozen}

News and Announcements 


\section{CALL FOR ARTICLES}

We welcome manuscripts of I5-25 pages, double spaced, on topics related to basic and ESL writing, broadly interpreted. Submissions should follow current MLA guidelines. Manuscripts are refereed anonymously. To assure impartial review, include name(s), affiliation(s), mailing and e-mail addresses, and a short biographical note for publication on the cover page only. The second page should include the title but no author identification, an abstract of about I5O words, and a list of 4-5 key words. Endnotes should be kept to a minimum. It is the author's responsibility to obtain written permission for including excerpts from student writing.

We prefer that contributions be submitted as Word document attachments via email to: hopekcc@aol.com and Cheryl.Smith@baruch.cuny.edu. If electronic submission is not possible, mail five copies of the manuscript and abstract to:

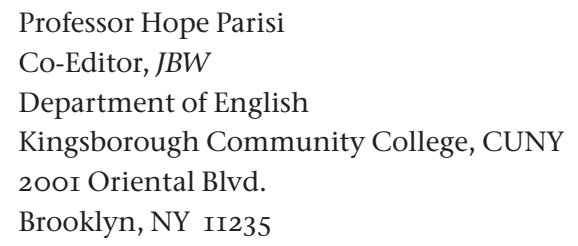

You will receive a confirmation of receipt; a report on the status of your submission will follow in about sixteen weeks.

All manuscripts must focus clearly on basic writing and must add substantively to the existing literature. We seek manuscripts that are original, stimulating, well-grounded in theory, and clearly related to practice. Work that reiterates what is known or work previously published will not be considered.

We invite authors to write about such matters as classroom practices in relation to basic-writing or second-language theory; cognitive and rhetorical theories and their relation to basic writing; social, psychological, and cultural implications of literacy; discourse theory; grammar, spelling, and error analysis; linguistics; computers and new technologies in basic writing; assessment and evaluation; writing center practices; teaching logs and the development of new methodologies; and cross-disciplinary studies combining basic writing with psychology, anthropology, journalism, and art. We publish observational studies as well as theoretical discussions on relationships between basic writing and reading, or the study of literature, or speech, or listening. The term "basic writer" is used with wide diversity today, sometimes referring to a student from a highly oral tradition with little experience in writing academic discourse, and sometimes referring to a student whose academic writing is fluent but otherwise deficient. To help readers, therefore, authors should describe clearly the student population which they are discussing.

We particularly encourage a variety of manuscripts: speculative discussions which venture fresh interpretations; essays which draw heavily on student writing as supportive evidence for new observations; research reports, written in non-technical language, which offer observations previously unknown or unsubstantiated; and collaborative writings which provocatively debate more than one side of a central controversy. 


\section{EDITORS' COLUMN}

It has been several weeks since the Superbowl riveted the attention of millions of football fans in a common interest: to mark with enthusiasm for one's team the gain of yardage across a field. For those of us who teach basic writing, we note a parallel: In basic writing, as in football, there are few seamless, field-long progressions. Setting goals and moving toward them is a conflictive process, typically one of advancement and return. Fortunately, however, our profession aspires to new directions; no dashing to demarcated end zones for us! As Bruce Horner observes, "locating" basic writing is a constant process of re-locating it, marking - and allowing for-its varied movements, such that each innovation adds to the complexity of our endeavor.

The articles of this issue speak to basic writing's reality of progressions and returns. Steve Lamos' article, “Minority-Serving Institutions, RaceConscious 'Dwelling,' and Possible Futures for Basic Writing at Predominantly White Institutions," prompts us to recognize that, as an institution, Basic Writing is not alone in its struggle to offer ensured access to the academy for marginalized students. As Lamos notes, minority-serving institutions provide longstanding traditions of accessibility and outreach. Expanding on Nedra Reynold's notion of "dwelling" as an inspired form of engagement with and within spaces that challenge educational fairness and justice, Lamos looks to MSIs as models of educational leadership that spark race-conscious ideologies, practices, pedagogies, and service-learning activities. In this way, MSIs are poised to counteract the "contemporary neoliberal higher education climate" that has widely restricted options for basic writers. By tracing the correspondences between MSIs and Basic Writing, Lamos helps our field envision new spatial and discursive embodiments of educational equity and social justice.

Our next article, "Troubling Discourse: Basic Writing and ComputedMediated Technologies" by Leigh Jonaitis, delimits current thinking about technology and basic writers. Jonaitis interrogates some dominant "stances" (as set out by Bertram Bruce) toward computer-mediated technologies to expose the fault lines in their assumptions as to what basic writers do or do not need, or what basic writers can or cannot do. In the process, Jonaitis returns us to a more relevant understanding of D/discourse, acknowledging Gee while pushing toward Foucault: it is Foucault's alignment of discourse, social practices, power relations, and knowledge construction that best helps us to recognize the influences, both institutional and technological, actively constructing the basic writer. Hence we can assess each of the stances Jonaitis critiques along political lines. As Jonaitis contends, basic writing instructors 
“cannot be 'neutral' toward computer-mediated technologies in the classroom: whether or not one is addressing computer-mediated technologies in the classroom, one is taking a stance that is decidedly not neutral." Nor is technology something one "adds" to writing instruction, or an element to merely transform it. Like Lamos, Jonaitis returns Basic Writing to essential values of equity and justice that require basic writers to fully participate in evolving literacy.

In our third article, "Interrogating Texts: From Deferent to Efferent and Aesthetic Reading Practices," Cheryl Hogue Smith works to renew our understanding of basic writing classrooms as reading classrooms as well. In Smith's truly integrated reading and writing approach, Louise Rosenblatt's theories of efferent and aesthetic reading stances find entrée into basic writing as a field that likewise encompasses reading. Smith leads from efferent and aesthetic stances to a third one, the "deferent" stance, prevalent among basic writers. The deferent stance, she writes, is "adopt[ed] when [basic writers] defer their interpretations of text to other readers or defer to the counter-productive emotions they experience during the process of reading difficult texts." From here, Smith offers an instructional strategy that engages students in rigorous, collaborative re-readings, such that students "examine their own thinking as they read difficult texts and . . . focus more on what they don't understand than on what they do." Reading actively, students experience their returns to the text as constructive, exploratory processes and opposed to failures of comprehension. Academic progression in literacy happens by way of return.

Our next two articles are literal returns to individuals whose basic writing-themed stories have previously appeared in the pages of this journal. In "Steep Houses in Basic Writing: Advocating for Latino Immigrants in a North Georgia Two-Year College," Spencer Salas revisits his "Sweet Water College" series of ethnographic narratives focusing on Taylor St. John, a sensitive teacher of ESL students who sees her own "interpretive" advocacy work as essential to her teaching. Once more, Salas elaborates the ways in which political, institutional constraints, counteracting an open admissions agenda, impact instructors' roles within and beyond the classroom. This is especially the case for instructors like St. John who are critically in touch with their job's social justice mission. In "Steep House," Salas reports on a highly contentious town hall meeting on immigrants' right to access a postsecondary education in the face of threatening state legislation. St. John's advocacy for illegal immigrants, whom the legislation would exclude from postsecondary education, rankled people's notions of teachers who stand in solidarity with these students and why their work matters. As well, Salas challenges Basic 
Writing as a discipline historically committed to open admissions to engage more explicitly with state legislation aimed at excluding immigrant youth from opportunity structures of our society.

Finally, Kevin Roozen returns his student, Charles, to these pages in "Comedy Stages, Poets Projects, Sports Columns, and Kinesiology 34I: Illuminating the Importance of Basic Writers' Self-Sponsored Literacies." Proceeding from his earlier article on extraliterary activity and basic writers, Roozen explores Charles's journey beyond his basic writing designation. Now in his second year at the university, Charles continues to draw on an array of involvements that offer greater access not only to interdisciplinary course content but also to styles and strategies of writing that mine rich, prior writing experience. As a result, Charles excels. Roozen's article also returns us to his earlier theoretical framework, emphasizing the extent to which broad literacy development can be repurposed toward basic writers' success with writing in the academy. As before, Roozen's picture of Charles prompts us to notice students' ability to productively multitask with their own literacy/ ies and seek pedagogies that elevate students' literate talents.

The spirit of progressions and returns mapped in this issue is captured by a longtime reader's gift of a nearly complete set of this journal's work since its inception in 1975 through 1996. Barbara Kroll, Professor Emerita of California State University-Northridge, has donated her personal copies in the hope that current and future scholars will benefit from the experience of holding - in their own hands - the words and labor of the progressive scholars who have helped lay our foundations (see News and Announcements for more information). Kroll's donation and the authors in this issue remind us to plot those points where our most forward-thinking teaching, administration, and research intersect with the past.

—Hope Parisi and Cheryl C. Smith 


\title{
Minority-Serving Institutions,
}

\section{Race-Conscious "Dwelling," and Possible Futures for Basic Writing at Predominantly White Institutions}

\author{
Steve Lamos
}

ABSTRACT: This essay looks to Minority-Serving Institutions (MSIs) for strategies that can be implemented in order to combat contemporary neoliberal attacks against the programmatic and institutional spaces of basic writing within Predominantly White Institutions (PWIs). Working from Nedra Reynolds' notion of thirdspace-oriented "dwelling" and Derrick Bell's notion of "interest convergence," it identifies four race-conscious "dwelling strategies" currently employed by MSIs to promote student success. It then offers four complementary suggestions regarding specific ways in which we in BW might adapt similar race-conscious dwelling strategies in the effort not only to defend our programs against contemporary attacks, but also to grow and cultivate new BW spaces within PWIs.

KEYWORDS: basic writing; space; racism; race-consciousness; Minority-Serving Institutions; Predominantly White Institutions; dwelling; interest convergence

\section{RACE AND THE INSTITUTIONAL SPACES OF BASIC WRITING}

Many of us who work in basic writing (BW), and especially those of us who work in BW programs within the context of predominantly white institutions (or PWIs for short), consider our programs to be "race-conscious" spaces-that is, spaces where relationships between and among issues of race, racism, language, and literacy can be openly interrogated, challenged, and reformed when students learn how to write. In this sense, many of us are inspired by assertions like those of Deborah Mutnick that "basic writing[,] for all its internal contradictions, has played a vital role in increasing access to higher education, in particular for working-class people of color" (7I-72). Unfortunately, many of us working in BW also know only too well

Steve Lamos is Associate Professor in the Program for Writing and Rhetoric and the English Department at the University of Colorado-Boulder. His publications include the book Interests and Opportunities: Race, Racism, and University Writing Instruction in the Post-Civil Rights Era (Pittsburgh UP, 20II) and articles appearing in CCC, College English, Journal of Basic Writing, and Writing Program Administration. Currently, Lamos is working on a book analyzing the roles of professional writing teachers within the research-focused academy.

(C) Journal of Basic Writing, Vol. 3I, No.I, $2 \mathrm{OI2}$ 
that race-conscious BW spaces have been disappearing with increasing frequency during the last fifteen years or so. BW has been eliminated across the four-year CUNY campuses as part of the termination of its Open Admissions program, fundamentally redefined at the University of Minnesota as part of the dismantling of the General College program, undermined at the University of South Carolina (along with Rhonda Grego and Nancy Thompson's important "Studio" model for BW), and lost within a number of other institutions described within Nicole Greene and Patricia McAlexander's book Basic Writing in America. Additional losses within the context of twoyear institutions also seem imminent: Pima Community College, one of the largest community colleges in Arizona, is currently attempting to establish baseline placement scores for all of its programs, thereby limiting its longstanding open admissions mission (see Pallack); meanwhile, legislation in Connecticut is currently being debated that would eliminate all remediation from two-year and four-year schools alike (see Fain).

Certainly, this widespread loss of BW space has a great deal to do with the increasing influence of neoliberal impulses that are reshaping higher education, especially PWIs. BW spaces are being or already have been eliminated from four-year and two-year PWIs as these institutions increasingly compete, both nationally and internationally, for ranking and prestige as a function of variables such as faculty research productivity, grant money, student ACT scores, and the like (see Hazelkorn; Ward). The logic driving BW elimination seems to be that institutions cannot compete for prestige if they support supposedly "illiterate" students who do not belong within their walls in the first place.

BW spaces are also being eliminated from PWIs in keeping with the sense that these "remedial" programs can be repackaged and resold as part of larger for-profit educational entities. For instance, one of the individuals responsible for making the decision to end Open Admissions within CUNY four-year schools in I999 was Benno Schmidt, a former president of Yale and then-chairperson of the Edison Group, a for-profit K-I2 charter school manager. Higher education critics Patricia Gumport and Michael Bastedo point out that Schmidt, along with many other members of the Task Force that decided to terminate Open Admissions on CUNY's four-year campuses, stood to generate a good deal of profit once responsibility for remediation could be shifted away from CUNY and toward the companies that they were associated with (343). And, certainly, Schmidt and his Task Force colleagues were enacting a kind of logic in I999 that has become increasingly prevalent since. Andrew Rosen, CEO of Kaplan University, has recently argued that for- 
profit higher educational institutions can and should target underprepared and underrepresented students as an increasingly important "down-market" group that is largely uninterested in traditional educational institutions. For-profit institutions should target this down-market, Rosen says, in much the way that "Wal-Mart and Target [aim] at mass-market consumers who'd prefer to save money rather than shop in a pricey department store" (34-35). In this sense, transforming "remedial" programs such as BW into downmarket profit generators seems to be increasingly attractive, especially in a world where higher education increasingly resembles a big-box superstore.

It is certainly worth recognizing, however, that there are other types of higher education spaces outside of the PWI that seem able to maintain a focus on providing effective race-conscious instruction-including race-conscious literacy and writing instruction-even amid contemporary neoliberal pressures. One such space is that of the Minority-Serving Institution (MSI), which is composed of the Historically Black College and University (HBCU), the Hispanic-Serving Institution (HSI), the Tribal College and University (TCU), and the Asian-American-Native-American-Pacific-Islander-Serving Institution (AANAPISI). More than 430 MSIs are presently operating throughout the U.S. to educate roughly 2.3 million students (Harmon 4), including I $6 \%$ of all African Americans, $42 \%$ of all Hispanics, and $19 \%$ of all Native Americans enrolled in U.S. higher education (Harmon 4). Furthermore, more than half of these MSIs possess an open admissions mission (Cunningham and Leegwater I78) while most serve "a large number of economically and academically 'at risk' students" (Gasman, Baez, and Turner 6). But especially important to my point here is the fact that most MSIs perceive issues of social and racial justice as central to their missions, even as they serve students from all racial and cultural backgrounds (Gasman, Baez, and Turner 3), and even as they receive significant amounts of federal funding, totaling hundreds of millions of dollars annually, to perform their work. ${ }^{\mathrm{I}}$ In a crucially important sense, then, MSIs operate as explicitly race-conscious (as well as class-conscious) higher education spaces that are managing to thrive, despite the many pressures that they face within our contemporary higher education climate. ${ }^{2}$

In the hope of addressing and ultimately reversing the troubling loss of race-conscious BW space within the PWI, I analyze here some of the specific strategies and techniques through which contemporary MSIs successfully cultivate and promote race-conscious education for their students. I then discuss some of ways in which we in BW can begin to adopt these MSI strategies and techniques in order to preserve-and perhaps even to expand and grow-the operation of our own race-conscious spaces within PWI contexts. 


\section{Minority-Serving Institutions}

To help me do so, I draw directly on two theoretical concepts: Nedra Reynolds' notion of “dwelling” and Derrick Bell's notion of "interest convergence."

\section{THEORETICAL FRAMEWORKS: REYNOLDS' “DWELLING” AND BELL'S “INTEREST CONVERGENCE”}

Composition theorist Nedra Reynolds defines "dwelling" as the process whereby embodied human beings - that is, human beings whose bodies are marked by differences such as race, gender, sexuality, and so on-interact with both the natural and built environments that they inhabit in ways that actively create and re-create new spaces. For Reynolds, dwelling constitutes the process whereby racialized individuals make choices about where, how, why, and how long to remain in, engage with, and / or reflect on particular spaces in ways that directly impact how these spaces are constructed. She writes:

People's responses to place-which are shaped in large part by their bodies, by the physical characteristics they carry with them through the spatial world-determine whether they will 'enter' at all, or rush through, or linger-and those decisions contribute to how a space is 'used' or reproduced. (I43)

Reynolds further stresses that dwelling is intimately tied to the construction of discursive space, arguing that

Discourses don't have roofs or walls or provide shelter, but as many of us recognize from favorite books or stories, discourses can hold memories or represent a meaningful time and place; if familiar, they invite us to dwell within them. If unfamiliar or strange, it takes much longer, and dwelling doesn't happen when people feel excluded or that they don't belong. (I63)

Finally, Reynolds stresses that dwelling serves as a mechanism by which to analyze how individuals can create both physical and discursive spaces of "resistance to the dominant culture" (I4I) - or what she later terms "thirdspaces" in ways resonant with the work of critical geographers such as Henri LeFebvre, Edward Soja, Doreen Massey, and others. Reynolds thereby argues that, during the course of actively dwelling within various physical and discursive spaces, racialized individuals can also dwell upon unfair and 
unjust practices and relationships within those spaces in ways that can foster thirdspace-oriented change-including change aimed at remedying the troubling effects of racism.

Reynolds' notion of dwelling sheds important light onto some of the key practices-what, for the purposes of this essay, I will call "dwelling strategies"-through which Minority-Serving Institutions are ultimately able to create and maintain race-conscious institutional spaces in the ways that they do. By employing various dwelling strategies, MSIs create thirdspaces in which students are invited to consider how issues of race and racism profoundly shape their educational and literate lives. Furthermore, by employing these dwelling strategies, MSIs challenge the loss of race-conscious space within our contemporary neoliberal higher education climate: these strategies help MSIs to insist that issues of race and space matter fundamentally to educational success in ways that cannot easily be dismissed amid the neoliberal rush for prestige and profit. Or, to put things more simply, MSIs use dwelling strategies to assert that race-conscious educational spaces must be preserved, not eliminated, within contemporary higher education.

In turn, critical race theorist Derrick Bell's notion of "interest convergence" is important for understanding how and why MSI-sponsored dwelling strategies can serve as models to those of us seeking to preserve BW in the context of the PWI. Bell argues that mainstream race-based educational reform efforts (and we can certainly include BW programs among such efforts) need to be perceived as benefitting mainstream white institutions in order to have long-lasting effects within the larger U.S. educational system. Specifically, Bell contends that these efforts need to be perceived as operating within a system where race-based reform "where granted, will secure, advance, or at least not harm societal interests deemed important by middle- and upper-class whites" ("Brown" 22). Bell does acknowledge the glaring irony in this situation: if racial justice efforts ultimately depend on and require the approval of the white mainstream in order to be deemed worthwhile, then such efforts may end up being "of more help to the system we despise than to the victims of that system we are trying to help" ("Racial Realism" 308). Nonetheless, he ultimately concludes that, if we can attend to interest convergence dynamics carefully and critically, we can foster successful institutional change in the form of "policy positions and campaigns that are less likely to worsen conditions for those we are trying to help and more likely to remind those in power that there are imaginative, unabashed risk-takers who refuse to be trammeled upon" (308).

Interest convergence offers us a particularly important tool with which to understand how and why MSI-style race-conscious dwelling can ultimately 
prove appealing within the context of the contemporary neoliberal PWI. Its principles suggest that race-conscious dwelling will be perceived as important and worthwhile within the PWI to the degree that it forwards PWI goals and interests-goals and interests which do still include the cultivation of at least some level of diversity within the PWI student body. As a quick illustration of this, consider the rhetoric currently being employed by Michael Crow, the well-known current President of Arizona State University and self-described "academic entrepreneur." In the midst of describing his institution as a model for the entrepreneurial (read: neoliberal) PWI of the future, Crow insists that Arizona State must seek to "champion diversity and ... accommodate the many gifted and creative students who do not conform to a standard academic profile, as well as those who demonstrate the potential to succeed but lack the financial means to pursue a quality four-year undergraduate education" (5). He further insists that Arizona State must "advance global engagement" (3) by serving the needs of international students as well as students from "immigrant households where the primary language is not English" (8). Through such rhetoric, Crow espouses a kind "neoliberalism for PWI diversity" stance, one asserting that prestige, profit, and diversity all fit neatly together. To be sure, we in BW ought to approach such neoliberal rhetoric with great caution, especially given the ways in which it threatens to conceptualize racial, ethnic, linguistic, and cultural diversity as nothing more than assets to be traded by powerful PWIs in the pursuit of their own interests. But we can nonetheless view this sort of rhetoric as offering an important opportunity to assert that our BW programs and the raceconscious dwelling that they promote are fundamental to PWIs' collective ability to achieve their goals of diversity and globalism. In other words, we can assert that the proclaimed diversity interests of PWIs converge directly with our own BW interests in race-conscious dwelling in ways that ought to be recognized and embraced.

\section{MSIS, DWELLING STRATEGIES, AND THE CREATION OF RACE- CONSCIOUS INSTITUTIONAL THIRDSPACES}

With this combined framework of Reynolds' dwelling and Bell's interest convergence in mind, I turn now to four specific types of race-conscious dwelling strategies that MSIs routinely use to help interrogate and reform racist social and educational spaces both within and beyond the academy. These include cultivating and supporting explicit race-conscious educational ideologies and practices, offering race-conscious and spatially-oriented writ- 
ing pedagogies, emphasizing race-conscious service-learning and community service activities, and documenting race-conscious institutional success. Each of these dwelling strategies helps to transform the MSI into a thirdspace of critical reform and change that opposes the neoliberal elimination of race-conscious space within higher education.

\section{MSI Dwelling Strategy \# I: Cultivating and Supporting Explicit Race-Conscious Educational Ideologies and Practices}

One of the first important ways in which MSIs promote dwelling is by proclaiming both explicitly and publicly the relationship that they imagine between their work and issues of social and racial justice-by proclaiming, that is, a kind of overt race-consciousness in terms of their institutional missions, goals, and values. MSI researchers Terrell Strayhorn and Joan Hirt describe such race-consciousness as a "defining characteristic" of MSIs (2IO). Meanwhile, other MSI scholars suggest that this defining characteristic is expressed in somewhat unique ways across different MSI contexts. Within HBCUs, for instance, Elaine Copeland finds a particularly close relationship between race-consciousness and community engagement, arguing that the "Emphasis [at HBCUs] has been and continues to be on cultural values, ethics, character development, civic responsibility, leadership, and service to the [African American] community" (53). ${ }^{3}$ In the context of HSIs, Christina Kirklighter, Diana Cardenas, and Susan Wolff Murphy suggest that there is often an explicit emphasis on race-consciousness within the space of the campus: they describe this as the HSI desire to "educate all students, particularly Latino/a students" (3) as part of a larger effort to develop spaces of "difference and educational activism" (I). ${ }^{4}$ With respect to the TCU context, Justin Guillory and Kelly Ward argue that there is often a particular stress on Native American languages and cultures which is designed to promote "cultural pride and hope" (9I). Finally, with regard to AANAPISIs, Julie Park and Robert Teranishi contend that there is a conscious effort to subvert the stereotype of the Asian American as "model minority," especially given the tendency of this stereotype to "overshadow the unique needs of the broader [Asian American] community and underserved groups" (I22). MSI operation and race-consciousness thus go hand-in-hand, even if the expression of this race-consciousness may vary slightly from institutional type to institutional type.

Accompanying this ideological emphasis on race-consciousness within the MSI is an explicit emphasis on student success—-that is, on a "belief that 
all students can learn, regardless of their entering level [of] preparation, and that the role of the institution is to do everything possible to ensure [this]" (Bridges, Kinzie, Laird, and Kuh 228). Such a success orientation is evident in the fact that so many MSIs have open admissions policies predicated on the idea that all students can succeed, regardless of past educational experiences or backgrounds. This orientation is further evident in the fact that many MSIs offer explicit student support mechanisms, especially during the first two years of the undergraduate experience. These mechanisms include firstyear support and community-building programs (e.g., "First Year Experience" courses and sequences, bridge programs, and intensive mentoring programs) as well as other advising and feedback programs providing support from faculty and staff. HBCU researcher and administrator Henry Ponder suggests that, on the whole, these kinds of support programs attempt to ensure that "first-year [MSI] students...[possess] the necessary motivation to maximize their efforts and take responsibility for their own learning" (I27). MSI researchers Terrell Strayhorn and Melvin Terrell echo this point, suggesting that these mechanisms, especially when staffed by faculty members who work closely with undergraduate students, aim to establish "a close-knit community where students [feel] part of the institutional fabric of the campus" (I47).

By espousing an explicitly race-conscious mission, and by coupling this mission with specific race-conscious student support mechanisms, MSIs directly encourage students' successful dwelling. MSIs serve, in other words, as race-conscious "safe spaces" from which students can spend significant time reflecting on the important relationships between a larger racist U.S. culture and their own education as college students. At the same time, MSIs routinely offer race-conscious institutional and material support to students as they dwell, especially in the form of small courses where students are likely to feel a sense of community and belonging, mechanisms that monitor students' academic process and offer extra assistance as needed, and a climate that values frequent and meaningful contact between students and faculty. Furthermore, in stark contrast to many mainstream PWIs, which tend to marginalize student support mechanisms into "remedial" programs or other ghettoized activities in ways that are frustratingly familiar to those of us in BW, race-conscious support mechanisms are viewed as absolutely central to the MSI experience. By stressing race-conscious dwelling in these ways, MSIs ultimately challenge the neoliberal contention that contemporary race-conscious spaces ought to be eliminated from the academy. Instead, MSIs insist, race-conscious spaces need to be preserved and expanded because they are absolutely essential to students' success within higher education. 


\section{MSI Dwelling Strategy \# 2: Offering Race-Conscious and Spatially- Oriented Writing Pedagogies}

A second means by which MSIs promote dwelling is by providing race-conscious and spatially oriented writing pedagogies and curricula. Carmen Kynard and Robert Eddy argue, for instance, that MSIs in general and HBCUs in particular foster at least three important race-conscious writing pedagogies, each premised on identifying and integrating of various types of institutional and discursive spaces. The first of these involves cultivating "Trans-school literacies" (W38), which arise when students integrate and transform home literacies and school literacies into new hybrid thirdspace literacies. The second involves "Collaborative-community teaching and learning" (W38) practices, which require students to bridge classroom and community spaces through various types of race-conscious service-learning and community engagement activities. The third involves fostering "Critical local-national understandings" (W38), which arise from "interrogat[ing] the politics of [students'] institutions, the social crises of their neighboring communities, and their own experiential knowledge as co-terminous realities" (W38). In these ways, Kynard and Eddy argue that HBCUs encourage a focus on the racialized nature of literacy "standards" as they are manifest within and across different spaces, from local to global, in ways that promote thirdspace interrogation and transformation.

A similar relationship between and among issues of race, space, and literacy is posited by Christopher Schroeder within the context of HSI writing pedagogy. HSIs promote, he says, "an alternative model of literacy that can authorize the locations that [their] students and others must negotiate as they write and read" (280). Furthermore, by focusing this issue of "location"-the issue of where students write, for what purposes, and to what audiences-HSIs ultimately concentrate

less upon approximating a target discourse or upon producing a product and more on the act or performance of negotiating...differences....[HSI writing pedagogy moves] beyond the rejecting of deficiency and embracing difference to seeing difference, particularly the negotiation of differences-linguistic, cultural, epistemological, institutional-as a basic practice of intellectual work. (280)

For Schroeder, then, HSI writing pedagogies demand that students engage carefully and critically with what it means to write and read across spaces 
in ways that enable them to recognize, negotiate, and transform the problematic power differentials that they encounter.

Still further, Beatrice Mendez-Newman describes some of the key raceconscious pedagogical attitudes and practices that she believes are frequently fostered within the space of HSI writing courses. In particular, she argues that these courses emphasize the need for Freireian critical awareness on the part of teachers: "It is difficult not to rely on Freireian constructs in attempting to understand the HSI environment. There is, when the instructor is white, a profound difference between the teacher / authority figure and the learners" (I9). As well, she says that HSI courses demand a race-conscious and supportive teacher attitude toward student literacy learning, asserting that "pedagogical content is far less important than pedagogical attitude. If an environment of trust and respect is not established in the classroom, little if any learning will occur" (I9). Finally, she describes a number of specific pedagogical orientations that she sees as crucial to the HSI writing classroom, including I) critical engagement with the label of "ESL" student as it often fails to apply to many students at HSIs, 2) careful engagement with patterns of error in the context of students' writing, 3) envisioning classrooms as promoting race-conscious "communities of learners," and 4) ensuring that teachers are as accessible to HSI students as possible (23). ${ }^{5}$ Thus, for Mendez-Newman, the HSI writing classroom effectively requires race-conscious teaching of many varieties.

Through these types of race-conscious pedagogies and teacher orientations, MSIs posit that dwelling is a decidedly literate practice that spans the spaces of home and school simultaneously. At the same time, MSIs characterize literacy as one of the most important products of successful MSI-centered dwelling - that is, as a set of skills, practices, beliefs, and habits of mind that can be used within, across, and beyond university spaces to do substantive race-conscious work in the world. MSIs thereby challenge neoliberal logic once again: rather than conceding that "remedial" writing instruction does not belong in the contemporary college or university, MSIs insist that spaces for race-conscious literate dwelling are indispensable to any college or university setting that purports to educate students for a diverse and global world.

\section{MSI Dwelling Strategy \#3: Emphasizing Race-Conscious Service- Learning and Community Service Activities}

MSIs also promote dwelling through race-conscious service-learning and community engagement programs, especially those focused on writing 
and literacy instruction. The value of these programs is evident within a recent special issue of the journal Reflections: A Journal of Writing, Community Literacy, and Service-Learning, which focuses on a range of programs currently being offered by faculty at HBCUs. This issue highlights, for instance, servicelearning activities and curricular options currently being enacted at Spelman College in Atlanta, including a linked "First-Year Experience Seminar" and "Sophomore Experience Seminar" requiring participation in and writing about a sustained local volunteer commitment of students' choice (Jordan 47-8), student volunteer work with and research at a local library dedicated to African American history and culture (49-52), tutoring work with a local middle school (52-55), and work with local teen drinking and drug prevention programs (56-7). It highlights similar initiatives at Jackson State University in Mississippi: as part of the first-year writing curriculum, students are required to participate in a local grade-school tutoring program during one semester (McDaniels, Harrion, Glenn, and Gentry II5-I9) and to work with a number of local women's groups during the next semester (I2O-22). Still further, it describes efforts at North Carolina Central University requiring first-year writing students to engage in a letter writing partnership with a local high school designed to "unite and empower [these] two academic communities" (Faulkner-Springfield 66).

Central across these types of HBCU service-learning and community engagement efforts is the way in which they view literacy as bridging the spaces of classroom and community: as Riva Sias and Beverly Moss summarize, these efforts "reveal the close, even 'seamless,' historical, political, and cultural relationship of African American literacy practices and African American community partnerships" (2-3). Also notable is the fact that these HBCU efforts are being mirrored in other MSI contexts, including HSIs and Tribal Colleges, ${ }^{6}$ in ways suggesting that the integration of school and community spaces is central to much MSI writing and literacy instruction. And, finally, these MSI service-learning and community engagement efforts offer an important contrast to the more superficial versions of such programs that sometimes arise at other types of institutions, including many mainstream PWIs. Angelique Davi characterizes such uncritical programs as "often populated by white students who are asked to go into poor urban areas to work with diverse communities, and there is a tendency for these students to view community service as [solely] an opportunity for self-fulfillment" (74). Davi's point here is not, of course, that middle-class white students cannot engage in successful or worthwhile service-learning or community engagement activity in the context of a writing course. Rather, her claim is 
that, when mainstream whites and others engage in this type of activity in uncritical fashion, they run a serious risk of letting the desire to feel good trump the actual doing of good for communities of color, a problem that threatens to reify the very social and racial order that these programs claim to be reforming. MSIs, in contrast, seem well prepared to avoid these problems: because they possess race-conscious missions, support mechanisms, and pedagogies, these institutions are explicitly committed to creating authentic race-conscious thirdspaces that seek to challenge the extant social order directly through writing and literacy work.?

In these ways, MSI-sponsored service-learning and community engagement programs do a great deal to promote race-conscious student dwelling. They focus not only on students' dwelling activities within the context of MSI writing classroom but also at the intersection of MSI writing classrooms and community spaces. Or, to phrase things differently, MSIs try to replace divisions between "town" and "gown" with a kind of town-and-gown thirdspace that is explicitly dedicated to reforming the social order through literacy instruction. MSIs thereby insist that contemporary colleges and universities have a responsibility to preserve and expand spaces for such race-conscious literate dwelling, both within their walls and within the larger community, rather than simply allowing these spaces to be eliminated in the pursuit of neoliberal goals.

\section{MSI Dwelling Strategy \# 4: Documenting Race-Conscious Institu- tional Success}

Many MSIs are, lastly, attempting to document the positive effects of race-conscious dwelling on factors such as student graduation and retention. This documentation helps to offer "proof" that MSIs provide a worthwhile and effective education, especially for students of color.

Numerous scholars note, for example, that MSIs graduate students of color at considerably higher rates than their peer predominantly white institutions. Noel Harmon points out that MSIs award a far greater percentage of BA degrees in education than their predominantly white counterparts do, including $46 \%$ of such degrees nationally for African-American students, $49 \%$ for Hispanic students, and I $2 \%$ for Native American students (6). He notes, too, that MSIs have especially strong track records in Science, Technology, Engineering, and Math (STEM) fields at the BA level, awarding approximately $4 \mathrm{I} \%$ of all STEM degrees for African American students and 54\% for Hispanic students (6). Meanwhile, Jaime Merisotis and Kirstin McCarthy mention that 
$38 \%$ of TCU students initially obtaining an AA degree ultimately managed to obtain a BA, while less than $\mathrm{I} \%$ from mainstream schools did (53). These statistics suggest that MSI contexts are especially conducive to improving minority students' overall graduation chances.

Another important issue that MSIs routinely highlight is that of undergraduate retention and transfer from two-year AA programs to four-year BA programs. This issue is stressed by Merisotis and McCarthy with respect to both TCUs and HBCUs. Regarding the former, they mention that TCUs had early I990s retention rates of about $57 \%$, contrasting starkly in with PWI retention rates hovering at around $\mathrm{I} \%$ (50). Regarding the latter, they mention that HBCUs increase the likelihood that students of color will initially enroll in and graduate from four-year BA programs rather than two-year AA programs by nearly $20 \%$, an especially important statistic given that that "students who enroll in four-year schools are more likely to complete a bachelor's degree than those who begin at a two-year school" (53). These figures further indicate that MSIs are having documented positive effects on students' chances of remaining in school long enough to graduate with a BA.

Finally, a large number of MSIs are currently participating in research programs and activities designed to publicize their positive effects more widely. One such contemporary effort titled the "Lumina MSI Models of Success Program" ${ }^{8}$ is helping MSIs to demonstrate their efficacy with regard to graduation, retention, and satisfaction rates for students of color. This program presently involves more than twenty institutions and institutional consortia spanning HBCUs, HSIs, TCUs, and AANAPISIs, and it aims to describe the specific ways in which MSIs (which Lumina describes as "recognized leaders in educating and graduating students of color" [Harmon I5]), engage in practices that are relevant to all higher education institutions. Another effort titled the "Building Engagement and Attainment for Minority Students" (BEAMS) project seeks to demonstrate the value of MSIs in terms of educating students in the hard sciences, and it is currently operating at IO2 MSIs nationwide (DelRios and Leegwater 3). Its goal is to ensure that MSIs can measure and broadcast their benefits despite the fact that many such institutions have traditionally had limited budgets and infrastructures for doing so.

By documenting their work in these various ways, MSIs are actively attempting to prove that their race-conscious dwelling activities produce measurable results, especially in terms of minority student graduation and retention rates. These documentation efforts further attempt to show that MSIs deserve continued funding and support for future student dwelling: 
indeed, as Pegeen Riechert-Powell argues, data on topics such as graduation and retention rates are foundational to virtually all institutions' "efforts [to] realize financial gains, in the form of tuition dollars, state funding, or future graduates' support as alumni" (667). But it is also important to point out that these MSI documentation efforts, while certainly participating in neoliberal discourses of assessment and accountability as promoted by sponsors such as the Lumina Foundation, ultimately perform a kind of critically minded thirdspace work. MSIs are, in effect, using neoliberal measurement techniques and discourses to prove that their race-conscious dwelling activities are demonstrably beneficial. By doing so, they seem to be trying to "flip the script" of typical neoliberal assessment, using this assessment to prove quantitatively that race-conscious spaces need to be preserved rather than eliminated within the contemporary academy.

\section{DWELLING STRATEGIES AND RACE-CONSCIOUS THIRDSPACES FOR BASIC WRITING}

Having discussed these race-conscious MSI dwelling strategies, I now turn to the questions of what might it mean for BW programs to invite students to dwell successfully within the larger context of the PWI and how such dwelling might help to preserve BW spaces in the present and future. In the hope of answering these questions, I discuss four MSI-inspired dwelling strategies that I believe we can adapt for use in PWI-sponsored BW programs. These strategies include telling explicitly race-conscious stories regarding BW, developing and publicizing new race-conscious writing pedagogies within BW, developing new race-conscious BW program and support structures, and documenting the success of race-consciousness within BW. Each of these strategies posits that BW can and should operate as a type of race-conscious thirdspace within the context of the PWI. Each further posits that oftenproclaimed PWI interests in student diversity and globalism converge directly with BW interests in promoting race-conscious dwelling-all in ways that render BW spaces indispensable to the future of the PWI.

\section{BW Dwelling Strategy \# I: Telling Explicitly Race-Conscious Stories}

As a first MSI-inspired dwelling strategy, we should imagine ways to engage in race-conscious BW "story-changing" work of the sort advocated by Linda Adler-Kassner: this work is designed to afford us a clearer "voice in the frames that surround our work and the tropes that emanate from those 
frames regarding our classes and students" (37). Specifically, we should imagine new ways to identify and publicize BW as an institutional space explicitly dedicated to success for the increasingly diverse populations that are entering PWIs in greater numbers. These populations include not only U.S.born students of color but also speakers of English as a global language and "Generation I.5" students. Speakers of English as a global language consist of individuals who learned English alongside their other native language(s), often in contexts shaped by colonialism: these students are "native speakers" of English in their homelands even though their native varieties and dialects of English may be different from "standard" versions spoken in places such as the U.S., Britain, or elsewhere (see Canagarajah, "Codemeshing"; "The Place"). "Generation I.5" students, meanwhile, consist of those who may have been born abroad but have had some amount of formal schooling in the U.S. (See Matsuda; diGennaro; Ortmeier-Hooper). They may well need some second-language writing assistance; however, they are also likely, "as a result of their experience in U.S. schools, [to be] familiar with U.S. education, teenage popular culture, and current slang" in ways that differentiate them from international ESL students (diGennaro 65-66). As Paul Kei Matsuda asserts, BW programs must try to serve these types of students in ways that overcome a "distinction between basic writers and second language writers [that] is becoming increasingly untenable" (83). Furthermore, because both of these populations are increasingly prominent within PWIs, we in BW need to stress our ability to serve them effectively: Ryuko Kubota and Kimberly Abels point out that these populations are often highlighted as central to PWI efforts to "internationalize," and so PWIs are facing increasing pressure to provide them with new "educational opportunities and resources" (83).

What would such story-changing concerning race-conscious BW dwelling within the PWI actually require? Taking a direct cue from the work of MSIs, it would require our telling new BW stories that highlight our desire to serve all PWI students, but especially to serve diverse students. We could insist, in other words, that one of the primary missions of BW within the PWI is to offer race-conscious writing and literacy instruction for students of color, speakers of global Englishes, Generation I.5 students, and others, to support these students with small classes that promote race-conscious dwelling explicitly, and otherwise to ensure students' successful retention and graduation. By telling such stories, we would thus be working against the neoliberal claim that the sole contemporary function of BW is to provide costly "remediation" for "unprepared" students who have no place in higher education. Instead, we would be insisting that BW provides critical 
assistance that helps diverse students to dwell successfully within the PWI context until they graduate. Such new stories would thereby assert that PWI interests and BW interests in diversity converge directly, and that they do so to the clear benefit of students.

Such race-conscious BW story-changing would also offer a useful rejoinder to the arguments of a number of scholars who seem to perceive the telling of race-conscious stories regarding BW as outdated, or even somewhat regressive, within the contemporary academy. ${ }^{9}$ Greene and McAlexander take such a stance, for instance, when they assert that it is an "oversimplification" to continue viewing BW through explicitly race-conscious analytical lenses (8): they argue that, "although the basis for hostility to basic writing programs in the early years might have involved racism, that hostility was later more strongly fueled by intellectual elitism" (8). Greene and McAlexander then conclude that we in BW ought to stop focusing at length on issues of race and racism when we talk about BW, acknowledging instead that our programs "cut across race, ethnicities, and class" (7). ${ }^{\text {Io }}$ I agree that essentialist thinking about issues of race and racism is problematic, especially when it serves to mask classism or intellectual elitism in ways that Greene and Alexander note. I also recognize that contemporary BW programs do serve students from a range of racial, cultural, linguistic, and social class backgrounds, including many mainstream and working-class whites (see Horner and $\mathrm{Lu}$ ). But I nonetheless contend that it is worthwhile to tell new race-conscious stories regarding contemporary BW spaces and the kinds of dwelling activities that they promote in order to highlight convergence between the interests of PWIs and the interests of race-conscious BW programs.

\section{BW Dwelling Strategy \# 2: Developing and Publicizing New Race- Conscious Writing Pedagogies}

In order to encourage MSI-inspired BW dwelling further, we can begin to theorize and implement BW pedagogies that are explicitly designed to help diverse populations succeed within PWI contexts. Toward this end, we can examine the potential value of the writing pedagogies currently being employed by MSIs in various writing courses, including some of those described earlier. For instance, both Kynard and Eddy's discussion of transschool literacies and Schroeder's emphasis on negotiating the "locations" of literacy seem quite helpful for fostering PWI students' critical engagement with the world from the vantage point of BW thirdspace. Mendez-Newman's suggestions regarding teacher attitudes also seem useful for ensuring that 
PWI students are being given the chance to engage in race-conscious dwelling successfully within BW.

At the same time, we should investigate the value of other contemporary BW pedagogies aimed at encouraging race-conscious dwelling within the PWI. For instance, within "Professing Multiculturalism: The Politics of Style in the Contact Zone," Min-Zhan Lu discusses the various ways in which written "errors" on the part of students from multicultural backgrounds can become the focus of explicitly race-, culture-, and class-conscious BW instruction. Her "can able to" example, which discusses a seemingly simple ESL mistake written by a Chinese-speaking student, illustrates how talk of error, authorial agency, and meaning can become central to any BW space. By exploring ways to adopt this kind of pedagogy more widely within the context of PWI-situated BW courses, we can ensure that all students are encouraged to use our courses as dwelling spaces from which to investigate, understand, and draw on their existing linguistic strengths, cultural backgrounds, and individual agency. ${ }^{\mathrm{II}}$

We should pay further attention to "translanguaging" pedagogies as tools for promoting race-conscious dwelling within PWI-situated BW courses..$^{12}$ Suresh Canagarajah defines translanguaging as the capacity of the multilingual and multidialectical individual to "shuttle between diverse languages, treating the diverse languages that form their repertoire as an integrated system" ("Codemeshing" 4OI) ${ }^{13} \mathrm{He}$ also implies that pedagogies rooted in translanguaging are likely to promote race-conscious dwelling for at least two reasons. First, these pedagogies are profoundly concerned with spatial dynamics ("The Place" 598) in ways that resonate strongly with the creation of race-conscious BW thirdspaces within the PWI: they are centrally concerned, in other words, with the question of "how we can accommodate more than one code within the boundaries of the same text" (598) in "rhetorically strategic ways" (599). Second, these pedagogies promote important emotional and ethical orientations from both students and teachers that fit squarely with race-conscious dwelling in BW. They assume that

multilingual people always make adjustments to each other as they modify their accent or syntax to facilitate communication with those who are not proficient in their language. Furthermore, they come with psychological and attitudinal resources, such as patience, tolerance, and humility, to negotiate the differences of interlocutors. ("The Place" 593-594) 
Translanguaging pedagogies thus clearly posit that students should attempt to understand and respond to their world using all the racial, cultural, linguistic, and attitudinal resources at their disposal.

By theorizing and implementing these sorts of race-conscious pedagogies, we can insist that diversity interests within the PWI will be promoted directly by the type of race-conscious dwelling that we espouse within BW-especially as we focus on issues of race, space, and literacy simultaneously, as we interrogate notions of student "error" to promote metacognitive and rhetorical awareness of writing and language skills, and as we promote the kind of patience, tolerance, and humility that characterizes positive learning for all manner of diverse students. Furthermore, we can insist that, because we in BW have been engaged in this kind of race-conscious pedagogy as a field for more than forty years, we possess a uniquely successful track-record and knowledge base that deserves to be preserved and supported within the PWI.

\section{BW Dwelling Strategy \#3: Developing Race-Conscious Programs and Support Structures}

As a third possible BW dwelling strategy, we need to continue developing and implementing MSI-inspired program and support structures that translate race-conscious BW ideologies and pedagogies into institutional action within the PWI. Fortunately, it would seem that BW already has a good start toward such development, especially given our long history of offering literacy learning support to students.

As one example of such a structure, consider Rhonda Grego and Nancy Thompson's Studio model for BW, which was originally developed at the predominantly white University of South Carolina but has since been adopted at a number of locations across the U.S. ${ }^{14}$ This Studio model provides small group meetings where students from across a number of first-year courses meet to talk about their assignments, to engage in peer review of one another's work, and otherwise to discuss the demands being placed on them by writing courses across the space of the university (I2-I3). The Studio thereby prioritizes the explicit support of students in their other classes, forming a kind of instructional thirdspace: the "students and their work, not any course instructor's plan, provide the 'curriculum' of the studio sessions" (IO). Furthermore, the specific version of the Studio developed by Grego and Thompson ended up supporting a good deal of race-conscious instruction at both the University of South Carolina and Benedict College, a nearby HBCU. In particular, it helped students and teachers to understand and respond to implicitly racialized university expectations 
about course requirements at USC (IO4) as well as to examine various racialized disciplinary expectations about writing and knowledge making (I34-I4O); it also prompted instructors at both South Carolina and Benedict to draw critical conclusions regarding issues of race, schooling, and their own teaching practices (I88-I99).

Even while recognizing these successes of Grego and Thompson's Studio, however, we can imagine ways to expand its race-conscious work even further, perhaps with the aid of something like the aforementioned translanguaging pedagogies. For instance, we might try to modify the Studio model slightly so that it offers some sort of "mini-curriculum" designed to have students rewrite assignments for other courses using various translanguaging techniques. Or, we might have the Studio engage all of its students, whether U.S-born, foreign-born, Generation I.5, or otherwise, in explicit discussion of the language politics undergirding the writing assignments that they receive across the PWI. Developing explicitly race-conscious versions of Studio programs like these would certainly help to increase BW students' chances for effective race-conscious dwelling.

As another example of a worthwhile BW support structure, consider the race-conscious BW service-learning program currently operating within the predominantly white space of Bentley College under the direction of Angelique Davi. Davi argues that this course, which encourages BW students to tutor nearby elementary school students, offers a unique dwelling space from which students of color can examine racialized educational practices and power relations:

In a service-learning composition course [like the one at Bentley]. . .. students of color may find themselves with opportunities to think critically about their lived experiences both inside and outside the classroom, [as well as about] systemic oppression . . . and dominant ideologies. For example, students of color may find themselves recognizing more subtle forms of racism embedded in the educational system that may have contributed to their sense of their academic performance. $(76)$

Davi's service-learning course clearly encourages students to dwell upon the ways in which their existing racialized literacy practices are identified as "remedial" in one spatial context (i.e., the mainstream PWI) and as "expert" in another spatial context (i.e., that of their mentoring relationship with younger students) in ways that ultimately promote thirdspace awareness of the shifting nature of literate activity. In turn, this type of course might be adopted for use in other PWI contexts, thereby inviting a greater number of BW students to engage in 


\section{Minority-Serving Institutions}

careful analysis of how issues of race and racism directly impact multiple literate and educational contexts simultaneously.5

By stressing race-conscious BW structures of various kinds-whether Studio programs, service-learning / community engagement writing programs, or others-we can emphasize yet again the central importance and value of the kind of dwelling that BW promotes. We can stress, that is, that PWIs' interests in promoting a diverse and global campus are clearly furthered through the kinds of support programs that we in BW already offer. We might argue as well that the PWI need not reinvent the wheel by developing new kinds of raceconscious student support mechanisms; instead, it ought simply to support the race-conscious BW spaces that we have already been offering (and can easily offer more widely if provided with the proper support).

\section{BW Dwelling Strategy \#4: Documenting the Success and Value of Race-Consciousness}

Mentioned earlier in this essay are some of the specific ways in which MSIs have begun to document their successes with respect to issues of race-conscious dwelling. Drawing inspiration from this MSI activity, we in BW should seek to document the relationship between race-conscious BW spaces, the specific types of dwelling that we promote through them, and factors such as graduation and retention rates. And, certainly, we should use this documentation to make persuasive arguments to our PWI sponsors that BW programs deserve their continued and unequivocal support.

Some in BW have certainly already begun this work. Greg Glau, for instance, has recently examined enrollment, pass rates, and retention rates for various groups involved in the Stretch program at Arizona State (during a time before President Crow's tenure), focusing in particular on students of color (37). He notes that students from these groups who have enrolled in Stretch are more likely to pass freshman composition than those who take regular courses (38), that retention rates have improved since Stretch was implemented (38), and that these findings have proven useful in opposing last-minute administrative proposals to raise class sizes or otherwise compromise the kind of important work that the Stretch program performs (44).

Matthew McCurrie has similarly analyzed the value of the Summer Bridge program at Columbia College in Chicago, a program that primarily serves underrepresented minority students. His preliminary work indicates that students have a freshman fall-to-spring retention rate that has improved from $6 \mathrm{I} \%$ in 2004 to $68 \%$ in 2008 (although he also notes that this rate still lags behind 
the $84 \%$ retention rate for regularly admitted students) (44). From this data, McCurrie concludes that "summer bridge programs can play an important role in improving the learning experiences of at-risk students when they give prospective students a challenging college experience that prepares them for real college-level work and thus builds confidence" (44).

Peter Adams, Sarah Gearhart, Robert Miller, and Anne Roberts have also been tracking the course completion, retention, and graduation rates of students involved in the Accelerated Learning Program (ALP) at their home institution of the Community College of Baltimore County. They find that ALP "doubles the success rate [for course completion], halves the attrition rate [from the first year course], does it in half the time [to graduation]....and costs slightly less per student than the traditional model" (64). They are also currently involved in new research being conducted by the Community College Research Center at Columbia University that will track ALP pass rates, rates of overall college persistence, and other similar data for students from across varying racial and economic backgrounds (65). And their ALP program seems to be generating a great deal of enthusiasm: more than 80 schools nationwide are currently using some form of this program (Adams, personal communication), and interest in the program continues to grow on the basis of the kind of data that the ALP movement has generated thus far. Although ALP has not yet generated considerable amounts of race-conscious data per se, its current activities and popularity suggest that it is likely to do so soon.

Each of these current BW documentation efforts use the discourses and tools of neoliberal assessment to demonstrate that race-conscious dwelling has positive effects within the PWI. However, in order to engage in a kind of critical "script flipping" similar to that of our MSI counterparts, we need to provide even more of this type of work. By documenting our successes with race-conscious dwelling more fully, we can effectively stress the convergences between PWI interests and our own. We can also effectively demonstrate that PWIs are already reaping important benefits from BW in terms of minority students' graduation and retention rates - and that they stand to reap even more of these benefits if they expand their support for our work.

\section{CONCLUSION}

I want to end this discussion on a hopeful note. While it is true that many BW spaces have been lost within the context of the PWI over the last I5 years, it is also true that we are well-positioned to rebuild and strengthen these spaces with the help of MSI-inspired dwelling strategies that promote 
convergence between PWI and BW interests. It also seems clear that we can capitalize on growing disciplinary and national interest in BW spaces and issues of PWI diversity to help us do so.

At the level of the discipline, for instance, both 2012 CCCC Chair Chris Anson and 20I3 CCCC Chair Howard Tinberg have recently underscored the value and importance of BW space, in part at the urging of members of the Council on Basic Writing (CBW). Anson helped to facilitate a number of well-publicized 2012 sessions on the future of BW, including a particularly powerful session featuring BW luminaries Mike Rose, Lynn Troyka, and Peter Adams. Meanwhile, Tinberg's 20I3 CCCC "Call for Proposals" featured BW goals, missions, and students explicitly within the body of its text by stressing the ways in which "the novice or basic writer has been the subject of foundational work in composition studies" (par. I). Also notable is the fact that the 2013 Council on Basic Writing (CBW) conference will be hosting an event at CCCC 2013 titled "Basic Writing and Race: A Symposium" featuring scholars and teachers from a number of MSIs and PWIs. These individuals will be discussing BW activity within their respective institutions as well as imagining new hybrids of BW, MSI, and PWI scholarship. Issues of race-consciousness and dwelling, as well as possible convergences between various institutional goals, will certainly be discussed at length during this symposium.

This resurgence of disciplinary interest in BW and its race-conscious spaces can certainly help our efforts to understand, enact, and publicize race-conscious dwelling strategies for use in the PWI. This resurgence might inspire us, for instance, to take a cue from Reflections and its special issue on HBCU service-learning and community engagement by producing our own special issues and edited collections (perhaps even within the pages of $J B W$ ) that are explicitly dedicated to issues of race, thirdspace, and MSIinspired dwelling within PWI contexts. This resurgence might also inspire us to facilitate more regular networking and interaction between faculty teaching BW in both MSIs and PWIs, whether through organizations such as CCCC or CBW, through new conferences and symposia, or through new kinds of professional and institutional networks spanning MSIs, PWIs, and other spaces.

Meanwhile, at a more national level, neoliberal administrators like Arizona State's Crow have been garnering increasing media attention for their ideas about the role of racial and ethnic diversity within the PWI. In particular, Crow was named by Time magazine in 2009 as one of the ten most important administrators currently working in higher education, and he was 
praised in particular by the magazine for his attempts to serve "students with a wide range of backgrounds and abilities while giving elite public schools a run for their research money" (Fitzpatrick par. I). While we in BW obviously need to interpret such praise critically, we can nonetheless use it to help us call public attention to how we in BW have played, and must continue to play, a central role in ensuring that "students with a wide range of backgrounds and abilities" are ultimately well-served by the PWI of the future.

Such media attention might encourage us, for instance, to generate and circulate public responses from groups like CCCC and CBW that stress the central role of BW within the diverse PWI of the future. It might also prompt us to partner (albeit in decidedly critical ways) with neoliberal sponsors such as the Lumina Foundation, the Gates Foundation, and others to document further our successes with race-conscious dwelling within the PWI. It might even inspire us to try capitalizing on the very recent mainstream discourse tying President Obama's recent re-election to the increasingly diverse and global nature of the U.S. population. If groups such as CCCC or CBW could discuss the importance of race-conscious BW dwelling with the (admittedly neoliberal) U.S. Department of Education, thereby emulating recent actions of the Council of Writing Program Administrators in its own meeting with Arnie Duncan's staff, then we might make the case that BW supports diversity in ways that will benefit the Obama administration's educational agenda directly. Each of these strategies would stress convergence between national educational interests and the work of BW in ways that we have not yet fully explored or exploited.

We need to take advantage of our current moment, then, by thinking in race-conscious spatial terms about the future of BW space within the PWI. In particular, we need to recognize the important race-conscious dwelling work currently taking place within MSI thirdspaces and examine how this work directly challenges contemporary neoliberal thinking about the future of higher education. We also need to imagine ways to employ MSI-inspired race-conscious dwelling activity within our own BW thirdspaces-ideologically, pedagogically, materially, and rhetorically-in ways that can directly challenge neoliberal pressures to eliminate BW. And, finally, we need to make effective interest convergence arguments that can persuade PWI stakeholders that their interests and our BW interests align in ways that are profoundly important to our collective futures. 


\section{Notes}

I. HBCUs are funded by Title III, "Institutional Aid," of the Higher Education Act (Gasman 23), receiving approximately \$235 million during FY 20 II (U.S. Department of Education, “Title III Part B” n. pag.). HSIs are funded under Title V, "Developing Institutions," and received approximately \$I50 million during FY 2OII (U.S. Department of Education, "Developing Hispanic-Serving” n. pag.). TCUs are funded under Title III, receiving just under \$27 million in FY 2 OII (U.S. Department of Education, "American Indian" n. pag.). Finally, AANIPISIs also receive federal Title III funding, obtaining about \$I3.5 million in FY 2OII (U.S. Department of Education, "Alaska Native and Native Hawaiian" n. pag.).

2. This is not to say, of course, that MSIs operate outside of the influence of neoliberalism: these institutions certainly face their own pressures to cultivate particular kinds of prestige and profit. (See Gasman, Baez, and Turner; Harmon; Merisotis and McCarthy). But these institutions have nonetheless held fast to their central race-conscious goals and missions, even in response to these pressures, in ways that are worth understanding and emulating.

3. See also Taylor; Taylor and Helfenbein; Sias and Moss.

4. See also Schroeder; Contreras, Malcom, and Bensimon.

5. See also the many informative chapters within Kirklighter, Cardenas, and Wolff Murphy's volume on teaching writing in MSI contexts, especially Millward, Starkey, and Starkey; Ramirez-Dhore and Jones; Baca; Jaffe; Artze-Vega, Doud, and Torres.

6. See Kirklighter, Cardenas, and Wolff Murphy; Gasman, Baez, and Turner.

7. See also Deans.

8. I recognize that Lumina and other higher education foundations have been rightly critiqued for contributing directly to neoliberal pressures toward particular kinds of "accountability" (see Stuart). But, as I will articulate momentarily, MSIs possess the potential to work with Lumina and other similar foundations in decidedly critical ways. 
9. I recognize that a number of contemporary BW scholars, including William Jones, Bruce Horner and Min-Zhan Lu (see especially Representing the Other), Victor Villanueva (see especially Bootstraps; "On the Rhetoric"), Keith Gilyard (see especially Voices; "Basic Writing”), Deborah Mutnick, and others, have long been telling crucially important race-conscious stories about BW spaces past and present. I also recognize that other important BW work from the late I96os and early I970s from authors including Geneva Smitherman (see especially “God Don't Never” and Talkin'), Harvey Daniels (see especially "What's Wrong”), and Mina Shaughnessy (see especially "The Miserable Truth") has also featured explicitly race-conscious stories of student access to higher education. However, these particular race-conscious stories have not frequently been referenced within contemporary accounts of how and why BW spaces are disappearing from the PWI.

Io.For a useful critique of this type of colorblindness, see Kynard, "I Want To Be African."

II. Lu engages in additional analyses of the power dynamics of language and literacylearning within some of her other most well-known articles: see especially "Conflict and Struggle," "Living English Work," and "An Essay on the Work of Composition."

I2. See, for instance, Canagarajah, "Codemeshing”; Horner, Lu, Royster, and Trimbur; Kynard, “The Blues”; Young and Martinez.

I3. Canagarajah defines "codemeshing," meanwhile, as the "the realization of translanguaging in texts" (403) - that is, the ways in which individuals treat multiple languages and dialects "as part of a single integrated system" that also "accommodates the possibility of mixing communicative modes and diverse symbol systems (other than language)" (403).

I4. See Lalicker; Tassoni and Lewiecki-Wilson.

I5. See also Gabor; Pine. 


\section{Works Cited}

Adams, Peter. Message to the author. I5 May 2012. E-mail.

Adams, Peter, Sarah Gearhart, Robert Miller, and Anne Roberts. "The Accelerated Learning Program: Throwing Open the Gates." Journal of Basic Writing 28.2 (2009): 50-69. Print.

Adler-Kassner, Linda. The Activist WPA: Changing Stories about Writing and Writers. Logan, UT: Utah State UP, 20o8. Print.

Artze-Vega, Isis, Elizabeth I. Doud, and Belkys Torres. "Mas alla del ingles: A Bilingual Approach to College Composition." Teaching Writing with Latino/a Students: Lessons Learned at Hispanic-Serving Institutions. Eds. Cristina Kirklighter, Diana Cardenas, and Susan Wolff Murphy. Albany, SUNY UP, 2007. 99-II8. Print.

Baca, Isabel. "It Is All in the Attitude-The Language Attitude." Teaching Writing with Latino/a Students: Lessons Learned at Hispanic-Serving Institutions. Eds. Cristina Kirklighter, Diana Cardenas, and Susan Wolff Murphy. Albany: SUNY UP, 2007. I45-68. Print.

Bell, Derrick. "Brown v. Board of Education and the Interest Convergence Dilemma." Critical Race Theory: The Key Writings that Formed the Movement. Eds. Kimberle Crenshaw, Neil Gotanda, Gary Peller, and Kendall Thomas. New York: The New Press, I995. 20-29. Print.

---. "Racial Realism." Critical Race Theory: The Key Writings that Formed the Movement. Eds. Kimberle Crenshaw, Neil Gotanda, Gary Peller, and Kendall Thomas. New York: The New Press, I995 302-I2. Print.

Bridges, Brian K., Jillian Kinzie, Thomas F. Nelson Laird, and George D. Kuh. "Student Engagement and Student Success at Historically Black and Hispanic-Serving Institutions." Understanding Minority-Serving Institutions. Eds. Marybeth Gasman, Benjamin Baez, and Caroline Sotello Viernes Turner. Albany: SUNY UP, 2008. 2I7-36. Print.

Canagarajah, Suresh. "Codemeshing in Academic Writing: Identifying Teachable Strategies of Translanguaging." The Modern Language Journal 95.3 (2OII): 4OI-I7. Print.

---. "The Place of World Englishes in Composition: Pluralization Continued." College Composition and Communication 57.4 (2006): 586-6I9. Print.

Contreras, Frances E., Lindsey E. Malcom, and Estela Mara Bensimon. "Hispanic-Serving Institutions: Closeted Identity and the Production of Equitable Outcomes for Latino / a Students." Understanding MinorityServing Institutions. Eds. Marybeth Gasman, Benjamin Baez, and Caroline Sotello Viernes Turner. Albany: SUNY UP, 2008. 7I-90. Print. 
Copeland , Elaine Johnson. "Creating a Pathway: The Role of Historically Black Institutions in Enhancing Access, Retention, and Graduation." How Black Colleges Empower Black Students: Lessons for Higher Education. Ed. Frank W. Hale, Jr. Sterling, VA: Stylus, 2006. 5I-62. Print.

Crow, Michael. "The Research University as Comprehensive Knowledge Enterprise: The Reconceptualization of Arizona State University as Prototype for a New American University." Seventh Glion Colloquium. June 2009. Web. 8 Oct 2012.

Cunningham, Alisa, and Lacey Leegwater. "Minority Serving InstitutionsWhat Can We Learn?" Recognizing and Serving Low-Income Students in Higher Education: An Examination of Institutional Policies, Practices, and Culture. Ed. Adrianna Kezar. New York: Routledge, 20IO. I76-9I. Print. Daniels, Harvey. "What's New with the SAT?" English Journal 63 (I974): 6, II-I2. Print.

Davi, Angelique. "In the Service of Writing and Race." Journal of Basic Writing 25.I (2006): 73-95. Print.

Deans, Thomas. Writing Partnerships: Service-Learning in Composition. Urbana, IL: National Council of Teachers of English, 200o. Print.

Del Rios, Melissa, and Lacey Leegwater. Increasing Student Success at MinorityServing Institutions: Findings from the Beams Project. Institute of Higher Education Policy. March 2008. Web. I6 May 2012.

diGennaro, Kristen. "Assessment of Generation I.5 Learners for Placement into College Writing Courses." Journal of Basic Writing. 27.I (2008): 6I79. Print.

Fain, Paul. "How to End Remediation." Inside Higher Ed. 4 April 2OI2. Web. I6 May 2012.

Faulkner-Springfield, Shirley. "Letters to Young High School Students: Writing and Uniting an Academic Community." Reflections: Writing, ServiceLearning, and Community Literacy I0.2 (201I): 63-I07. Print.

Fitzpatrick, Laura. "Nine Presidents to Watch: Michael Crow." time.com II November 2009. Web. I7 November 2012.

Gabor, Catherine. "Writing Partners: Service-Learning as a Route to Authority for Basic Writers." Journal of Basic Writing 28.I (2009): 50-70. Print. Gasman, Marybeth. "Minority-Serving Institutions: A Historical Backdrop.” Understanding Minority-Serving Institutions. Eds. Marybeth Gasman, Benjamin Baez, and Caroline Sotello Viernes Turner. Albany: SUNY UP, 2008. I8-27. Print.

Gasman, Marybeth, Benjamin Baez, and Caroline Sotello Viernes Turner, Eds. Understanding Minority-Serving Institutions. Albany: SUNY UP, 2008. Print. 
Gilyard, Keith. Voices of the Self: A Study of Language Competence. Detroit, MI: Wayne State UP, I99I. Print.

---. "Basic Writing, Cost Effectiveness, and Ideology. Journal of Basic Writing I9.I (2000): 36-42. Print.

Glau, Greg. "Stretch at Io: A Progress Report on Arizona State University's Stretch Program." Journal of Basic Writing 26.2 (2007): 30-48. Print.

Greene, Nicole Pipenster, and Patricia J. McAlexander. Basic Writing in America: The History of Nine College Programs. Cresskill, NJ: Hampton, 2008. Print.

Grego, Rhonda, and Nancy Thompson. Teaching / Writing in Thirdspaces: The Studio Approach. Carbondale, IL: Southern Illinois UP, 2008. Print. Guillory, Justin P., and Kelly Ward. "Tribal Colleges and Universities: Identity, Invisibility, and Current Issues." Understanding Minority-Serving Institutions. Eds. Marybeth Gasman, Benjamin Baez, and Caroline Sotello Viernes Turner. Albany: SUNY UP, 2008. 9I-IIO. Print.

Gumport, Patricia J. and Michael N. Bastedo. "Academic Stratification and Endemic Conflict: Remedial Education Policy at CUNY." The Review of Higher Education 24.4 (200I). 333-49. Print.

Harmon, Noel. "The Role of Minority-Serving Institutions in National College Completion Goals." Institute for Higher Education Policy. Jan $20 \mathrm{O} 2$. Web. I6 May 2012.

Hazelkorn, Ellen. "The Impact of League Tables and Ranking Systems on Higher Education Decision Making." Higher Education Management and Policy I9.2 (2007): I-24. Print.

Horner, Bruce, and Min-Zhan Lu. Representing the 'Other': Basic Writers and the Teaching of Basic Writing. Urbana, IL: NCTE, I999. Print.

Horner, Bruce, Min-Zhan Lu, Jacqueline Jones Royster, and John Trimbur. "Language Difference in Writing: Toward a Translingual Approach." College English 73.3 (20II): 303-2I. Print.

Jaffe, Barbara. "Changing Perceptions, and Ultimately Practices, of Basic Writing Instructors through the Familia Approach." Teaching Writing with Latino/a Students: Lessons Learned at Hispanic-Serving Institutions. Eds. Cristina Kirklighter, Diana Cardenas, and Susan Wolff Murphy. Albany: SUNY UP, 2007. I69-92. Print.

Jones, William. "Basic Writing: Pushing Against Racism." Journal of Basic Writing I2.I (I993): 72-80. Print.

Jordan, Zandra. “'Found' Literacy Partnerships: Service and Activism at Spelman College." Reflections: Writing, Service-Learning, and Community Literacy I0.2 (20II): 38-62. Print. 
Kirklighter, Christina, Diana Cardenas, and Susan Wolff Murphy, eds. Teaching Writing with Latino / a Students: Lessons Learned at Hispanic Serving Institutions. Albany, NY: SUNY Press, 2007. Print.

Kubota, Ryuko, and Kimberly Abels. "Improving Institutional ESL/EAP Support for International Students: Seeking the Promised Land." The Politics of Second Language Writing: In Search of the Promised Land. Eds. Paul Kei Matsuda, Christina Ortmeier-Hooper, and Xiaoye You. West Lafayette, IN: Parlor Press, 2006. 75-93. Print.

Kynard, Carmen. “'I Want To Be African': In Search of a Black Radical Tradition/African-American-Vernacularized Paradigm for 'Students' Rights to Their Own Language,' Critical Literacy, and 'Class Politics.'” College English 69.4 (March 2007): 356-86. Print.

---. “'The Blues Playingest Dog You Ever Heard of': (Re)positioning Literacy Through African American Blues Rhetoric." Reading Research Quarterly 43.4 (2008): 356-73. Print.

Kynard, Carmen, and Robert Eddy. “Toward a New Critical Framework: Color-Conscious Political Morality and Pedagogy at Historically Black and Historically White Colleges and Universities." CCC 6I.I (2009): I7I; W24-W44. Print.

Lalicker, William. "A Basic Introduction to Basic Writing Program Structures: A Baseline and Five Alternatives." Teaching Developmental Writing: Background Readings. 3rd ed. Ed. Susan Naomi Bernstein. Boston: Bedford St. Martins, 2007. I5-25. Print.

Lu, Min-Zhan. "Conflict and Struggle: The Enemies or Preconditions of Basic Writing?" College English 54 (I992): 887-913. Print.

---. "Professing Multiculturalism: The Politics of Style in the Contact Zone." CCC 45.4 (1994): 442-58. Print.

---. "An Essay on the Work of Composition: Composing English against the Order of Fast Capitalism." CCC 56.I (2004): I6-50. Print.

---."Living English Work.” College English 68.6 (2006): 605-I8. Print.

Matsuda, Paul Kei. "Basic Writing and Second Language Writers: Toward an Inclusive Definition." Journal of Basic Writing 22.2 (2003): 67-89. Print.

McCurrie, Matthew Killian. "Measuring Success in Summer Bridge Programs: Retention Efforts and Basic Writing." Journal of Basic Writing 28.2 (2009): 28-49. Print.

McDaniels, Preselfannie E. Whitfield, Kashelia J. Harrion, Rochelle Smith Glenn, and Gisele Nicole Gentry. "African American Students Learn by Serving the African American Community: A Jackson State University Example of 'Challenging Minds and Changing Lives.'” Reflections: Writ- 
ing, Service-Learning, and Community Literacy I0.2 (20II): I08-35. Print. Mendez-Newman, Beatrice. "Teaching Writing at Hispanic Serving Institutions." Teaching Writing With Latino/a Students: Lessons Learned at Hispanic-Serving Institutions. Eds. Christina Kirklighter, Diana Cardenas, and Susan Wolff Murphy. Albany, NY: SUNY Press, 2007. 17-36. Print.

Merisotis, Jaime P. and Kirstin McCarthy. "Retention and Student Success at Minority-Serving Institutions." New Directions for Institutional Research I25 (2005): 45-58. Print.

Millward, Jody, Sandra Starkey, and David Starkey. "Teaching English in a California Two-Year Hispanic-Serving Institution: Complexities, Challenges, Programs, and Practices." Teaching Writing With Latino/a Students: Lessons Learned at Hispanic-Serving Institutions. Eds. Christina Kirklighter, Diana Cardenas, and Susan Wolff Murphy. Albany, NY: SUNY Press, 2007. 37-62. Print.

Mutnick, Deborah. "The Strategic Value of Basic Writing." Journal of Basic Writing I9.I (2000): 69-83. Print.

Ortmeier-Hooper, Christina. "English May Be My Second Language, But I'm Not 'ESL'." CCC 59.3 (2008): 389-4I9. Print.

Pallack, Becky. "Pima College Seeks to End Some Remedial Classes." Arizona Daily Star. I8 July 20II. Web. I6 May 2012.

Park, Julie J., and Robert T. Teranishi. "Asian American and Pacific Islander Serving Institutions: Historical Perspectives and Future Prospects." Understanding Minority-Serving Institutions. Eds. Marybeth Gasman, Benjamin Baez, and Caroline Sotello Viernes Turner. Albany: SUNY UP, 2008. III-26. Print.

Powell, Pegeen Reichert. "Retention and Writing Instruction." CCC 60.4 (2009): 664-82. Print.

Pine, Nancy. "Service-Learning in a Basic Writing Class: A Best Case Scenario." Journal of Basic Writing 27.2 (2008): 29-55. Print.

Ponder, Henry. "What Makes African American Students Successful at Historically Black Colleges and Universities: The First-Year Program." How Black Colleges Empower Black Students: Lessons for Higher Education. Ed. Frank W. Hale, Jr. Sterling, VA: Stylus, 2006. II9-28. Print.

Ramirez-Dhore, Dora, and Rebecca Jones. "Discovering a 'Proper Pedagogy': The Geography of Writing at the University of Texas-Pan American." Teaching Writing with Latino/a Students: Lessons Learned at HispanicServing Institutions. Eds. Cristina Kirklighter, Diana Cardenas, and Susan Wolff Murphy. Albany: SUNY UP, 2008. 63-86. Print.

Reynolds, Nedra. Geographies of Writing: Inhabiting Places and Encountering 
Difference. Carbondale: Southern Illinois UP, 2004. Print.

Rosen, Andrew S. Change.edu: Rebooting for the New TalentEconomy. New York: Kaplan Publishing, 2oII. Print.

Schroeder, Christopher. "Notes Toward a Dynamic Theory of Literacy." The Locations of Composition. Eds. Christopher J. Keller and Christian R. Weisser. Albany: SUNY UP, 2007. 267-88. Print.

Shaughnessy, Mina. “The Miserable Truth." Journal of Basic Writing I7.2 (I998): IO6-I2. Print.

Sias, Riva, and Beverly Moss. "Rewriting a Master Narrative: HBCUs and Community Literacy Partnerships." Reflections: Writing, Service-learning, and Community Literacy IO.2 (2OII): I-I6. Print.

Smitherman, Geneva. "God Don't Never Change: Black English from a Black Perspective." College English 34.6 (I973): 828-33. Print.

---. Talkin' and Testifyin': The Language of Black America. Boston: Houghton Mifflin, I977. Print.

Strayhorn, Terrell L., and Joan B. Hirt. "Social Justice at Historically Black and Hispanic-Serving Institutions: Mission Statements and Administrative Voices." Understanding Minority-Serving Institutions. Eds. Marybeth Gasman, Benjamin Baez, and Caroline Sotello Viernes Turner. Albany: SUNY UP, 2008. 203-I6. Print.

Strayhorn, Terrell L., and Melvin C. Terrell. The Evolving Challenges of Black College Students: New Insights for Policy, Practice, and Research. Sterling, VA: Stylus, 2oro. Print.

Stuart, Reginald. "Disproportionately Influential?" Diverse: Issues in Higher Education 27.I2 (2010): I6-I7.

Tassoni, John Paul and Cynthia Lewiecki-Wilson. "Not Just Anywhere, Anywhen: Mapping Change through Studio Work." Journal of Basic Writing 24.I (2005): 68-92. Print.

Taylor, Hill. "Black Spaces: Examining the Writing Major at an Urban HBCU.” Composition Studies 35.I (2007): 99-II2. Print.

Taylor, L. Hill and Robert J. Helfenbein. "Mapping Everyday: Gender, Blackness, and Discourse in Urban Contexts." Educational Studies 45 (2009): 319-29. Print.

Tinberg, Howard. "The Public Work of Composition: March I3-I6, 20I3." Conference on College Composition and Communication. Web. 9 Aug. $2 \mathrm{OI} 2$.

U.S. Department of Education. "Developing Hispanic-Serving Institutions Program-Title V." U.S. Department of Education. 5 Oct. 20II. Web. I6 May 2012.

---. “American Indian Tribally Controlled Colleges and Universities-Title 
III Part A Programs." U.S. Department of Education. I July 20II. Web. I6 May 2012.

---. “Title III Part B, Strengthening Historically Black Colleges and Universities Program.” U.S. Department ofEducation. I Jul. 20II. Web. I6 May 2012.

---. "Alaska Native and Native Hawaiian Serving Institutions-Title III Part A Programs." U.S. Department ofEducation. 30 Jun. 20II. Web. I6 May 2012.

---. "Asian American and Native American Pacific Islander Serving Institutions (AANAPISIs) Receive \$2.6 Million in Federal Grant Funding." U.S. Department of Education. 23 Nov. 20IO. Web. I6 May 2012.

Villanueva, Victor. Bootstraps: From an American Academic of Color. Urbana, IL: NCTE, I993. Print.

---."On the Rhetoric and Precedents of Racism." CCC 50.4 (I999): 645-6I. Print.

Ward, Stephen C. Neoliberalism and the Global Restructuring of Knowledge and Education. New York: Routledge, 20I2. Print.

Young, Vershawn Ashanti, and Aja Y. Martinez. Code-Meshing as WorldEnglish: Pedagogy, Policy, Performance. Urbana, NCTE, 2 oII. Print. 


\title{
Troubling Discourse: Basic Writing and Computer-Mediated Technologies
}

\author{
Leigh A. Jonaitis
}

ABSTRACT: Through an examination of literature in the fields of Basic Writing and developmental education, this essay provides some historical perspective and examines the prevalent discourses on the use of computer-mediated technologies in the basic writing classroom. The author uses Bertram Bruce's (I997) framework of various "stances" on literacy technologies to both contextualize discussion of technology in the field of Basic Writing and to consider implications for further discussion and research. By emphasizing the interrelatedness of technology and literacy, a "transactional" stance on computer-mediated technologies relies on the idea of literacy as a social practice, and would therefore align better with the overall values of the field of Basic Writing.

KEYWORDS: basic writing; computers; technology; discourse

In discussing the various "hopeful threads" of the first twenty years of the journal Computers and Composition, Charles Moran reminded the field of the "strong and persistent hope that computers would specifically advantage basic writers" (350). Despite the dramatic increase in technology usage on college campuses and research done on the use of computers in writing courses, this hope has not been fully realized. In basic writing classrooms, computer-mediated technologies often seem to be viewed as "add-ons," and in some cases, limited to word processing rather than online learning. In a recent exploration, Linda Stine finds that little is being said about basic writers and online education; accordingly, she calls for basic writing teachers and students to participate more fully in the online learning debate ("Basically Unheard" I4I). Though still not fully realized, the hope that computers will benefit basic writers persists.

As a community college instructor who has taught online composition and hybrid courses for basic writers for over twelve years, I am especially interested in the ways in which faculty view the use of computer-mediated technologies with basic writers. My experiences as an online instructor and

Leigh A. Jonaitis is Professor of English at Bergen Community College, where she has taught basic writing and composition courses, including online and hybrid courses, since 200o. She has served as Department Chair of English Basic Skills and as Adjunct Coordinator. She currently serves on the Regional Executive Committee of the Two-Year College English Association-Northeast (TYCA). 
writing program administrator of a community college basic writing program have continually re-shaped the ways with which I work and consider technology in the basic writing classroom. Such rethinking has led me to examine, interrogate, and "trouble" the prevalent discourses on the use of computermediated technologies in the basic writing classroom through current literature in the fields of Basic Writing and developmental education. This kind of work is even more important in light of Susan Naomi Bernstein's recent call for reinvigorated support for the I974 NCTE "Resolution for Motivated but Inadequately Prepared Students" and her specific recommendation that basic writing educators provide students "with necessary resources for obtaining an equitable education." While technology is not specifically mentioned as one of these resources, it can be inferred. I argue that not only must we recognize technology as one of several resources needed for an equitable education, but also consider how any use (or non-use) of technology in the basic writing classroom has political implications for our students' access to equitable education.

As such, I consider how the field of Basic Writing has framed the use of computer-mediated technologies with basic writers by using Bertram Bruce's (I997) framework of various "stances" on literacy technologies. Bruce articulates seven possible stances that educators can and do take towards computer-mediated technologies before ultimately urging educators to think beyond the separate entities of "literacy" and "technology." Bruce advocates for a transactional view of technologies, which "tells us that technologies do not transform or determine literacies, nor could they ever be irrelevant to literacy practices. Instead, they are part of the continual reconstruction of literacies" (303). By emphasizing the interrelatedness of technology and literacy, a transactional stance on computer-mediated technologies relies on the idea of literacy as a social practice. This essay examines how a transactional view would therefore provide a better starting point for those concerned with access issues in Basic Writing.

\section{Discourse and Defining the Basic Writer}

Proponents of New Literacy Studies (see Kress; Gee; Lankshear et al.; Street) point out that "reading and writing only make sense when studied in the context of social and cultural (and we can add historical, political, and economic) practices of which they are but a part" (Gee "New Literacy Studies" I77). James Paul Gee's definition of discourse is taken from a sociolinguistic perspective: 
"Discourses" are characteristic (socially and culturally formed, but historically changing) ways of talking and writing about, as well as acting with and towards people and things (ways which are circulated and sustained within various texts, artifacts, images, social practices, and institutions, as well as in moment-to-moment social interactions) such that certain perspectives and states of affairs come to be taken as "normal" or "natural" and others come to be taken as "deviant" or "marginal" (e.g., what counts as a "normal" prisoner, hospital patient, or student, or a "normal" prison, hospital, or school, at a given time and place). ("New Literacy Studies" I80)

Bruce Horner depicts what he calls the various discourses that have been used in the field of Basic Writing ${ }^{\mathrm{I}}$ since its inception at City College over 30 years ago. Such discourses include a "Horatio Alger" discourse, in which Basic Writing gave students "power" to succeed; a separate (but certainly unequal) discourse, in which students in remedial programs were perceived as being "at a particular stage in a natural sequence of learning" (208); and a "frontier" discourse, in which teachers of Basic Writing were considered "pioneers" of a "new profession" (2I0). Horner also contrasts the public discourse surrounding Basic Writing with the discourses used in the field itself, stating that "until discourse on the teaching of writing recovers the specific historical, material, institutional, and political context of that teaching and that discourse, it will be difficult for us to hear what study of the historical experience of literacy has to say" (220). As Horner makes clear, it is important to recognize the contexts in which such discourses about Basic Writing develop.

The use of computers in the basic writing classroom often falls into three categories: computer-assisted composition (word processing); computeraided instruction, which is often self-paced, such as grammar drills that are assessed by a computer program; and computer-mediated communication, which includes online programs and discussions. Much of the research initially done on the use of technology with basic writers was on computerassisted composition. Discussions were often focused on how basic writers either don't have access to computer-mediated technologies or whether or not word processing benefits them (see Moran; Crafton). More recently, there has been speculation about how the online environment can be beneficial to basic writers (Pavia), and whether fully-online courses for basic writers are advisable (Stine).

These are important considerations; however, as technology develops, there is a need to recover the context of these discourses in much the same 
way Horner urges us to do so with all discourse in Basic Writing. Some basic writers use mobile devices to communicate on a regular basis with friends and family, but have difficulty composing an essay on a computer. One basic writing class may meet in a computer lab where students are expected to develop an online portfolio of their work; another class might be required to take a final handwritten exit exam. We must specifically acknowledge how our basic writers use technology in their everyday lives, how that compares with how they are expected to use technology in the classroom, and what that might mean for our practice as teachers.

Pamela Gay challenges Stephen Bernhardt and Patricia Wojahn's assertion that much of what has been written about the use of computers and writing instruction "can be applied equally as well to both general and basic writing classes" (qtd. in Gay 72). While acknowledging that the field of basic writing can benefit from the research done in computer and composition, she points out that in considering the impact of computers on basic writing, "we also need to build on prior research with this (diverse) group of students placed in basic writing classes if we want to advance our learning and improve the teaching of basic writing" (72). I would add to this that we must not only consider the population we teach in basic writing classes, but also the implications of placing students in classes that do not award credit, and how the decision to not use computers-or to limit the use of computers in these classes-is ultimately a political choice, even if the motive behind such a move appears benign (faculty not having experience with computers, for example). Viewing technology as separate from literacy, for example, can permit teachers to unwittingly participate in a further stratification of our students. If we define the basic writer as a student who does not place into first-year writing at a specific institution, then this localized definition in turn creates the basic writer. As David Bartholomae points out, "we have defined basic writing (as a form or style of writing) by looking at the writing that emerges in basic writing courses....We know who basic writers are, in other words, because they are the students in classes we label 'Basic Writing'" ("Writing on the Margins" II2). Elsewhere, Bartholomae critiques developmental psychology as a way to think about basic writers:

Basic writers, we are asked to imagine, work with a style that is preacademic. They are caught in some earlier step in cognitive development (at the level of concrete rather than formal operations, for example), or they belong to a culture that is pretextual (an oral culture, like those that preceded the development of alphabetic writing) and that 
hinders the cognitive development required for literate participation in a textual culture. ("Teaching Basic Writing" II4)

The developmental approach, as Bartholomae critiques above, assumes that there is a linear progression that can occur from error-based writing to academic writing. Such an assumption is present in literature about the use of technology with basic writers-the developmental "linear progression" in these fields might begin at one end with word processing and end with fullyonline courses at the other. However, if technology and literacy are not seen as separate realms, but rather, as inextricably linked, and students have more advanced experience with literacy technologies than their teachers, then it is important to question a pedagogy that works within a developmental structure. Could it be that those of us who teach basic writing construct a hierarchy of literacy technologies as a way to make ourselves feel "safe" in unchartered territories?

In resisting the "autonomous model of literacy," Linda Adler-Kassner and Susanmarie Harrington echo Bruce Horner in reminding practitioners to consider the contexts within which our basic writers write. If, as they claim, Basic Writing is a "political act," it follows that the various uses (or non-uses) of computer-mediated technologies with basic writing are also political acts, each asserting claims about what basic writers can or cannot do. The desire to study basic writers' use of the computer as separate from first-year composition is also a political act. Thus, Bernhardt and Wojahn's claim that "much of what has been written [about writers and computers] can be applied equally well to both general and basic writing classes" (I66) might not be viewed as a dismissal of the importance of basic writers' use of computer-mediated technologies, but rather, as an acknowledgement of the very elusiveness of the term "basic writer." If basic writers are defined locally by the contexts in which they are taught, then the study of computermediated technologies with basic writers is also a local construction.

If each use of computers with basic writers can be seen as a "political act," then what kind of politics does each act adopt? Some historical perspective may prove helpful here. In the I99os, scholars in the field of Computers and Composition (Barton; Romano; Hawisher and Selfe), called for a more critical view of technology: one that would reexamine what they viewed as the essentially positive discourse(s) of the time. Ellen Barton analyzes what she calls the "discourses of technology." One, the "dominant discourse," is characterized by "an optimistic interpretation of technology's progress in American culture," while the other, in her view represented by the theoretical 
scholarship in English studies at the time, is the "antidominant discourse," characterized by "a skeptical interpretation of technology's integration in contemporary culture and education" (56). She equates the antidominant discourse with scholars on the cultural Left and the dominant discourse with neoconservative critics. Framing the various perspectives on technology as an either/or debate is helpful to a point, but does not address the multiple views of researchers, faculty, and students. As technology advanced and computers were increasingly used in writing classrooms, a greater variety of perspectives inevitably emerged.

Writing in 1997, Bertram Bruce acknowledges this variety by providing a useful framework for categorizing the faculty and scholarly discourses about the use of computers with students. Based on his interactions with literacy and technologies, he articulates seven possible "stances" that educators and researchers can (and do) take. These stances are described as "neutral," "opposition(al)," "utilitarian," "skeptical," "transformational," "aesthetic'," or "transactional" (290). Some of Bruce's stances are more aligned with the "dominant discourse" that Barton describes-that is, an essentially positive view of technology — while others could be seen as "antidominant." Others don't fit as neatly into such a binary. Even so, Bruce acknowledges that his is "an incomplete list of possible positions one might assume with respect to new technologies" (29I). Therefore, I use Bruce's stances on literacy technologies here merely as a way to begin to imagine new possibilities for the way basic writing teachers and scholars both view and use computermediated technologies with their students.

\section{Opposition(al) and Skeptical Stances on Technology}

According to Bruce, one who subscribes to an "oppositional" stance feels that "the inevitable uses of technology for surveillance, regimentation, and social stratification far outweigh the alleged benefits" (290). On the other hand, one who subscribes to a "skeptical" stance "does not see great dangers in technology, just overblown rhetoric about it" (29I). An oppositional stance is more likely to be found among faculty opposed to the use of technology with basic writing students, and less likely to be found in scholarship. This is probably a result of the nature of scholarship, and the overall pressure to use computer-mediated technologies in all disciplines at the college level. The "skeptical" stance is more likely to be found in basic writing research, even in work that would align itself mostly with the "utilitarian" or "transformational" stances. For example, working under the assumption that there 
is pressure to incorporate technology in basic writing classrooms, Catherine Matthews Pavia uses computers "only for word processing" in her basic writing classes, rather than more "complex" uses of computer-mediated technologies like Web page authorship (20).

Rather than a conscious rejection, most resistance to more current technologies comes from what I believe is a tacit assumption about what students supposedly need in order to pass a basic writing course. In some contexts, more "complex" uses of technology can be seen as an example of what Jeanne Gunner calls "critical" discourse. Drawing on Michel Foucault's theory of the author function, Gunner outlines tenets of "iconic" and "critical" discourse in Basic Writing. Iconic discourse "reproduces the field according to certain laws, always in relation to the iconic text and figure," while critical discourse "is transgressive, challenging the laws and the icon, and so is received with hostility by the traditional Basic Writing community" (27). According to Gunner, iconic discourse emphasizes the binaries of educator/administrator, teacher/scholar, and practitioner/theorist, and thus revolves around the construction of the altruistic and self-negating "iconic teacher-figure." Such a teacher-figure "works against the repressive social givens of a particular age" (3I) and values being an outsider in academia. In Basic Writing iconic discourse, conflict and struggle-particularly against administration-provide reason for the basic writing teacher to exist. In the context of administrative pressure to use computer-mediated technologies, then, iconic discourse may make faculty resistance to computer-mediated technology not only permissible, but also "natural."

This reluctance is based on the assumption that so-called "remedial" students will be challenged by learning more "advanced" technologies in addition to the writing tasks they have been assigned. Back in 1996, Robert Crafton articulated specific perils of word processing with basic writers and advocated a return to more "traditional methods" (325). He warned that the effects of word processing "may be relatively innocuous for sophisticated users of language and computers," but "the effects may be far more serious for basic writers and basic computer users, leading not to greater linguistic and rhetorical sophistication but to arrested development" (320). This resistance to more current technologies may be a cyclical trend in Basic Writing. In 2004, Pavia seems to feel that introducing anything other than word processing might be beyond the capability of basic writers. This echoes Crafton's concern, eight years earlier, that word processing itself is beyond the capability of basic writers. Such resistance is rooted in iconic discourse: there are assumptions about what basic writers can do, and also what they 
should do in the basic writing classroom. As pressure increases to eliminate remediation at both four-year and two-year colleges, there is an increased emphasis on the "basics" that a student needs to acquire before entering a first-year composition course. In this context, the use of computers for something like Web authorship may be seen as unnecessary.

Such concerns about the necessity of computer-mediated technologies in basic writing are not limited to computer-assisted composition. Fullyonline courses for basic writers are currently seen as especially deviant, in both the literature of the field and in faculty discussions. In a study of 256 online developmental writing students, Carpenter, Brown, and Hickman found that students who remained in the online class were more successful (as determined by course completion) than their face-to-face counterparts; however, they were less likely to remain in the course to begin with (35). While Linda Stine has had great success with hybrid courses for her basic writing students, she does not advocate fully-online courses, claiming that "Internet-based learning is not a natural fit for basic writing students" (33). Such a claim about what is not "natural" for basic writing students seems to rely on the assumption that online learning is dependent on their weaknesses (reading and writing) rather than their oral and aural strengths. However, the rapid advancement of video and audio capabilities have altered the landscape of online learning in recent years, opening up online possibilities for basic writers. Online course material that once had to be read can now be heard and viewed.

The National Center for Developmental Education has also expressed its opposition to online courses for basic writers in its book What Works: Research-Based Best Practices in Developmental Education, the very title of which reveals some of the discourses of the field of developmental education. The emphasis on "what works" implies that there are things that do (and do not) "work," and that one can definitively say what those things are (or are not) in any given context. But this begs the question: what does it mean to "work"-for whom, and in what contexts? Such concerns are not unique to developmental English, but they bear mentioning because there are possible implications for the use of computer-mediated technologies with basic writing. A practical discourse, or one that emphasizes what works or does not work, particularly in terms of the use of technology in the classroom with basic writers, can be viewed in light of an oppositional or skeptical stance: if the technology does not work with students in the classroom, then, the argument goes, such use should be abandoned. Nevertheless, if the technology does work for basic writers, then it is viewed as either enabling students to 
achieve outcomes already put in place (a "utilitarian" stance), or "transforming" them (a transformational" stance). These two stances are explored later.

If discourses contribute to certain perspectives and states of affairs being seen as "normal," then the "normal" perspective in this case is that basic writers can only learn what they need to learn by being in the physical classroom for at least part of the time. However, as of this writing, the idea of fully-online courses for basic writers is often summarily rejected, in both the literature of the field and in faculty discussions. Though resistance to basic writers in fully-online courses is not without reason, it seems wise to continually revisit those reasons in order to avoid relying on-or completely believing in-the socially-constructed assumption that all basic writers must learn in a physical classroom. Considering the rapid proliferation of online resources and access, rejecting this option for motivated and capable basic writers denies them a potential opportunity.

\section{Access}

One important reason educators and researchers might take up an "oppositional" or "skeptical" stance on technology with basic writers is a concern over basic writers' lack of access to computer-mediated technologies. Access is an incredibly important consideration for basic writers and computers. James Porter's definition of computer access for students includes “(I) infrastructure (money and machines), (2) literacy (education and training), and (3) community acceptance (freedom to speak online) (99)" (qtd. in Pavia I4). Citing the difficulty her basic writing students encountered in the context of Porter's last two criteria for access, Catherine Pavia challenges the notion that simply asking basic writers to use computers (and providing a computer lab in which to do so) grants them "access": "Access issues run deeper than computers, programs, availability, and use in a writing classroom-they stem from and encompass students' family, culture, and class genealogies that affect their interactions with the classroom component" (I8). Charles Moran claims that while most in the field of computers and composition acknowledge that access is an issue-indeed, access to technology for women and minorities is one that has been explored in depth-the relationship between wealth/class and access has not been comprehensively addressed in scholarship (206). Pavia believes that computer classrooms "provide students with access to choice" to write with the computer and "that the option to write with computers is a good one for basic writers" (I8). This reasoning implies that one has a choice to use the computer when writing. To what extent, though, has writing on a 
computer become less of a choice? How do we do our basic writing students a disservice when we fail to consider how instrumental the computer is to writing in the workplace and their personal lives?

At the community college where I teach, students enrolled in basic writing classes are required to meet in the computer lab for the "practicum" portion of the class at least once a week, if not more. Many of my own basic writing students express a general comfort with computer-mediated technologies, and most of them use such technologies on a daily basis. Most students use the Internet multiple times a day through social networking sites and mobile devices, and they are expected to use the computer to type papers for all of their classes. Many students note ways in which they feel their writing and language choices in their academic writing were affected as a result of computer-mediated technologies. Even students who claim to have the most difficulty using technology most often do not have major difficulties working with the computer in the lab. They are able to develop their writing in a word-processing program and post to course-required blogs successfully with little assistance from me. Many students now compose essays on their mobile devices and email them to me. Their experiences complicate some of the assumptions made about basic writers' use of computer-mediated technologies. I recognize that not all basic writing students will have the background with such technologies that my students had, and that the institutional status of Basic Writing may contribute to limited resources and often prohibit classroom use of technology and innovation. Nevertheless, my students' comfort with computer-mediated technologies points towards a need to consider the wealth of literacy practices that our basic writers bring to the classroom. When educators determine what students are (or are not) capable of when it comes to working with computers, they must be informed by the individual students' literacy practices, as well as the expectations they will face when they leave the classroom.

Although most of my students have more access to computer-mediated technologies in the classroom than seems to be acknowledged in the literature, the difference in access outside of the classroom must still be an important consideration. In the past few years, mobile devices have made their way into the lives and classrooms of basic writers. Questions about access have typically dominated the literature on the use of technology with basic writers; however, student participation in a full range of mobile technology should alter our perceptions about the use of technology in the classroom. Access is not only about considering whether or not students are experienced enough to use computer-mediated technologies in the classroom, but also 
how we as basic writing teachers address the access that students have to computer-mediated technologies outside the classroom. Issues surrounding access will continue to change as technology develops, and increased access will actually create a new kind of digital divide. Marisa Klages and J. Elizabeth Clark, writing in 2009, point out that the digital divide is moving beyond mere access to technology, but has become "rather a more complex divide of those who have the educational access, training, and critical engagement" required of academic and professional cyber-literacy (48). In addition, in the last five years, as access to digital devices has spread, there is early research to suggest that as a result of parental guidance, children from poorer families are spending much more time than children from more well-off families using their devices for purposes other than education (Ritchell). Once this generation enters college, such a divide could potentially have a significant impact on basic writing classes. Basic writing educators must consider students' pre-college literacy practices in light of this more complex kind of cyber-literacy. To not do so denies basic writers the necessary resources for obtaining an equitable education.

\section{High Hopes for Access: Utilitarian and Transformational Stances on Technology}

In Mary Soliday's view, most basic writing research "has always been especially concerned to identify, and then meet, students' needs" (4). This focus on student need (however that may be defined ${ }^{3}$ ) and what "works" is related to Bruce's characterization of the utilitarian stance on technology, in which "technology provides marvelous new tools for teaching and learning that can improve literacy education" (290). A utilitarian stance might then focus on students' "needs" and on the technology that can be employed to fulfill those needs. The findings of Stan and Collins's I 998 survey on the use of technology with basic writers seem to indicate that instructors who used technology with basic writers in the I99os were aligned with the utilitarian and transformational stances on technology; among other things, they found that "the positive evaluations of using technology overwhelmingly outweighed the neutral or negative ones" (32).

While scholarship on the various modes of educational technology use (computer-assisted composition, computer-aided instruction, and computer-mediated communication) might find a place within a utilitarian stance, it is computer-aided instruction that is most often considered utilitarian. Literature about publishers' software programs, which claim to 
assist students and faculty, take a positive stance on technology and often emphasize the ways in which such CAI programs help faculty and administrators to "manage" students ${ }^{4}$. This notion of computer-aided instruction addressing specific student "need" often relies on the idea of "self-directed learning." In Changing Literacies, Colin Lankshear and James Gee encourage a critical approach towards this concept of "self-directed learning" by "asking what constructions of 'self' and 'direction' are operating in this particular text, and why they are operating here" (94). The implication here is that the basic writer's ideal "self" and "direction" is clearly defined in terms of curricula. If one is operating under the utilitarian stance, however, there is not much room to question textbook-like computer-aided instruction, since such packages are usually viewed as an "add-on" to the basic writing curriculum. This "add-on" view also includes debates over whether basic writing courses can be done online, as well as research claims that hybrid courses represent the "best of both worlds" (Stine "The Best of"; Brown). If a hybrid course is considered to be the best of both worlds, then the assumption is that the classroom and the online space each inhabit its own "world" with its own sets of rules, drawbacks, and benefits.

The utilitarian stance is a difficult one to shake: writing about "technology" in and of itself places it as separate and outside of the field of Basic Writing. In that sense, even the subtitle of this essay_-Basic Writing and Computer-Mediated Technologies"-could indicate that I view computers in basic writing through the utilitarian stance. As with the oppositional and skeptical stances, a utilitarian stance contributes to assumptions about the place of computer-mediated technologies in basic writing classes. If technologies are, as Bruce claims, "part of how we enact texts and make meaning" (300), then viewing technology as a necessary (or unnecessary) "add-on" or as a "separate world" does not address the complex relationship between literacy and technology.

Those who argue that computer-mediated technologies are "transformational" think that they "will replace or radically transform the basic definition of literacy" (Bruce 29I). Though such "transformation" is seen as essentially positive, proponents of such a stance feel that educators' task is to understand and guide this transformation (29I). It is the positive perspective that links both the "transformational" and "utilitarian" stances, and therefore some scholarship on basic writers and computers (Stine "Best of"; Pavia; Kish; Cummings) could be categorized as both utilitarian and transformational. Linda Stine uses computer-mediated communication to argue for increased use of the hybrid environment (partly in-class and partly online) with basic 
writers: "the current structure of this basic writing course, with one week online and one week face to face in a classroom, seems to offer our students the best of both worlds: the infinite freedom of the Internet enhanced and made manageable by regular classroom interactions" (66). Stine employs the "best of both worlds" rhetoric, but also implies that it is the classroom interaction that "manages" the "infinite freedom of the Internet" (66). In explaining how basic writers can use computer-mediated communication to help with writer's block, Judith Mara Kish claims that "teaching with the computer and emphasizing the non-linear recursive opportunities in word processing may help students begin to see the possibilities of their texts" (I55). The transformational stance is implicit here in the assumption that students might not be able to see such possibilities without the use of the computer.

Beyond the possibility of transformation in the classroom, there is the possibility of institutional transformation. Charles Moran points out the continuing hope for improved professional status as a result of working with technology, emphasizing that "technophiles" typically want to effect educational reform through technology as a community rather than having such reform imposed on the discipline by institutional forces (353). In other words, providing "sites of resistance" provides for potential "transformation." Likewise, Jeffrey Grabill advocates the use of technology as a way for a basic writing program to gain legitimacy in the institutions which they serve. He challenges faculty reluctance to use new technologies with basic writers and demands that those in the field take a more active role in making decisions about their use-not just in the classroom, but on a departmental and institutional basis. In the "transformational stance," technology is seen as a savior, rescuing both student and programs from their lowly institutional status. More significantly, it is seen as an entity separate from the literacy practices of students, as are all of the stances discussed so far.

\section{Evolving Literacy: The Transactional View}

In Bruce's transactional view, technologies "are part of the continual reconstruction of literacies. As such, they too are constructed out of the evolving literacy practices" (303). Unlike the other stances he describes, Bruce emphasizes that the transactional view is not really an alternative stance, "but rather, a conception of a mutually constitutive relation between technologies and social practices" (303). He draws an analogy between the printing press and the chalkboard-we don't view these elements as separate anymore because they are so connected to notions of literacy. The question 
of whether students would compose better on computers (versus writing by hand) is now complicated by the fact that students do much (if not most) of their composing on the computer (or the cell phone or iPad). Basic writing teachers must recognize that "technology and writing are not distinct phenomena; that is, writing has never been and cannot be separate from technology" (Haas $\mathrm{x})$. Whether one is using a pen and paper or a laptop to compose, the technology becomes habitual enough that one eventually does not notice its use. Cynthia Selfe argues that this is precisely why we must be aware of the influences of emerging technologies on literacy. If indeed our use of computer-based activities drives curricular change in Basic Writing because we believe that the technology can "accomplish the goals of conventional literacy instruction better or more efficiently than traditional activities" (483), we are not acknowledging the symbiotic relationship between the two.

This symbiotic relationship between technology and literacy can be better understood through the idea of literacy as a social practice, as explored by The New Literacy Studies movement (see Gee; Kress; Street). For example, Brian Street offers a distinction between what he calls "autonomous" and "ideological" models of literacy: in his view, the autonomous model "works from the assumption that literacy in itself-autonomously—will have (benign) effects on other social and cognitive practices" (7). The danger in this model, as he asserts, is that it "disguises the cultural and ideological assumptions that underpin it so that it can then be presented as though they are neutral and universal" (77). It is therefore appropriate that the autonomous model has been taken up by researchers in Basic Writing in order to question some of the assumptions that basic writing teachers bring to the classroom. Linda Adler-Kassner and Susanmarie Harrington reference Street's work to point out that conversations about Basic Writing "do not often involve an examination of the ideological contexts in which...literacy skills are used" (6). The "linear narrative of writing ability" in Basic Writing described by Ann DelPrincipe-the belief in "a sequence of complexity to verbal acts and the parallel belief that discrete levels of ability correspond to the sequence of complexity" (65) — could be said to correspond with an autonomous view of literacy. In both interpretations, "literacy" is accepted as "neutral" and "universal." The other view that Street presents, what he terms the "ideological" model of literacy, posits that literacy "is a social practice, not simply a technical and neutral skill; that it is always embedded in socially constructed epistemological practices" (77). Bertram Bruce's call to abolish the distinction between "literacy" and "technology," then, makes sense in light of this view of the ideological model of literacy, in which literacy is always contested. 
By rejecting the autonomous model of literacy (Street) and the linear narrative of writing ability (DelPrincipe), basic writing educators can employ the transactional view in considering the interrelatedness of literacy and technology. The transactional view seems to address the complexity of the problem and lends itself well to the overall values of the field of Basic Writing; however, some of the other stances are so much a part of the discourses of computers and Basic Writing, it is difficult to think outside of them-specifically the utilitarian, skeptical, oppositional, and transformational stances. One example of the transactional view can be found in Cheryl C. Smith's exploration of students' use of a class blog. Acknowledging the effects of Web 2.0 on her students before they arrive in her composition classroom, she wonders if using such technologies can encourage risk-taking, promote classroom interactivity, and enable instructors and students to move beyond a focus on error. Though she is encouraged by the "democratic" potential of such classroom technology, she is wary of the promise of transformation (47). She urges the field to "interrogate the effect" that "Web 2.0 writing practice has on [students]: their thinking, style, and approaches to college writing" (55). In doing so, she encourages educators to consider not only how technology can assist students in the classroom, but also what technological experience students bring to that classroom. Such an argument transcends the transformational stance and moves into the transactional, in which new technologies do not merely assist in developing literacy but are informed by the view of literacy as a social practice. Another strong example of the transactional view can be found in Klages and Clark's consideration of the public nature of writing in the digital age. Their response to such a shift in literacy practices is to incorporate the multimodal nature of writing into their basic writing curriculum through the use of ePortfolios, blogs, and Web 2.o tools. Students move beyond written text to create multimodal works in order to "build on their technological dexterity" and "begin to understand their emerging writing skills as equally important components of their digital literacy" (39). It is not simply that the authors are doing multimodal work with basic writing students; rather, it is the ways in which they appear to view that work. The rationale behind Klages and Clark's curriculum reflects the idea that literacy is always contested and is therefore aligned with both Brian Street's ideological model of literacy and Bruce's transactional stance. In using what I would call the transactional view, both Smith's and Klages and Clark's work provide excellent examples of the kinds of conversations that we can and should have when thinking about the use of technology with basic writers. 
How can we begin to have these conversations with our students and ourselves? Shannon Carter provides a practical way to combat the autonomous model of literacy in her book The Way Literacy Lives: Rhetorical Dexterity and Basic Writing Instruction. She encourages teachers to examine more familiar literacies (or communities of practice) in order to better understand academic literacies that may not be as familiar to students. By applying the concept of rhetorical dexterity to the transactional view, teachers might ask students to reflect on the technological discourses students bring to the classroom-for example, asking them to consider the communication "rules" employed on a social networking site, and how those differ from texting, discussion boards, or e-mails. Such discussions help to make explicit the rules that govern different kinds of discourse, particularly in computer-mediated technologies that are textually-based. Instructors can ask students to consider the ways in which they use technological literacies every day. For many students, this is a literacy that they have likely not considered as worthy of study, and yet the exploration of this more familiar literacy provides a space to discuss the kinds of literacies expected in college.

A large part of the transactional stance requires that we are consistently aware of the new literacies that develop as a result of technological practice. This doesn't necessarily mean we as faculty need to be up-to-date with every single new technological innovation that emerges, but we do need to be aware of them, as well as how the technological hierarchies we construct for ourselves (and ultimately, for our students) perpetuate assumptions about what students "need." When instructors avoid using technology in the basic writing classroom because of a well-meaning concern about students' lack of access or familiarity with such technology, they are quietly rejecting a transactional stance in favor of a more comfortable one. Technologically self-critical instructors are aware of and explore with students the technological literacies that both students and instructor bring to the classroom. Consideration of technology in the basic writing classroom, then, is not a luxury, but instead a crucial part of considering the constantly evolving literacy practices that are such a large part of basic writers' lives.

\section{Discoursing Computers and Basic Writing}

The transactional view can not only guide how we address the use of computer-mediated technologies in the classroom, but also the discourses we use to consider and theorize the use of technology in Basic Writing. Initially, I explained James Gee's (2005) definitions of D/discourse, which might lead 
one to view Bruce's stances as discourses themselves. However, it seems to me that merely substituting "discourse" for "stances" fails to consider the ways in which discourse is historically, socially, and culturally contingent. Michel Foucault's definition of discourse may be more helpful in enabling the field to think about future research in computers and basic writing. Foucault conceives of discourses as "ways of constituting knowledge, together with the social practices, forms of subjectivity, and power relations which inhere in such knowledges and the relation between them" (Weedon Io8). Viewed through this perspective on discourses, Bruce's stances can be seen as discursive practices within the larger Discourse of Basic Writing (explored by, among others, Bartholomae; Bartholomae and Petrosky; Gunner; Horner; Horner \& Lu; Rose).

Foucault asks us not to define discourse, but to instead ask "how does discourse function?" This poststructuralist approach, as well as the notion of the transactional view, can enable us to think differently in future research by asking questions like the following:

- How does the interrelatedness of technology and literacy function in the basic writing classroom?

- In what ways are the political contexts of Basic Writing served by the use of technology?

- How does students' past and current work with computer-mediated technologies inform their writing in academic settings?

- Who benefits from the use of-and research about-such technologies in Basic Writing?

- How does access (or lack of access) to computer-mediated technologies impact basic writers?

- What are the disciplinary effects of computerized assessment practices-particularly placement-in Basic Writing?

- Why research the use of computer-mediated technologies specifically in Basic Writing classrooms (as opposed to composition classes)?

These questions are very different from the kind of questions often asked about the efficacy and purpose of such technologies, which too often focus on what basic writers need and how technology can serve those needs, or how basic writers potentially lack the access and ability to use technologies in the same ways as their peers not placed in basic writing. However, the above questions are important ones if one conceives of Basic Writing as a political act. 
Resisting the insular nature of discourse can be challenging. As a teacher and a researcher, I too rely on various discourses to think about the ways in which computers affect basic writers. While I believe that we need studies specifically addressing the ways in which computer-mediated technologies are used with and by basic writers, my reasoning is rooted in institutional concepts of Basic Writing, not in basic writing students themselves. That is, it is not the students that warrant a closer examination of these uses as much as the institutions and assessment practices (many of which are now computer-based) that create "basic writers." We are the ones who create the reasons and conditions to use computers with basic writing students, and not using technology with our basic writing students also has implications. Despite English teachers' overall preference that "technology remain quiet and well-behaved in the background of our lives" (2I), Cynthia Selfe urges them to consider the ramifications of technological literacy on their students' lives:

Teachers who choose not to use computers in class believe that their decision absolves them and their students from paying critical attention to technology issues. . . . allowing ourselves the luxury of such positions is not only misguided but also dangerously short-sighted. $(23-24)$

On the other hand, when computer-mediated technologies are used in the basic writing classroom, practitioners take an active role in making decisions about their use. Thus, one cannot be "neutral" towards computermediated technologies in the classroom: whether or not one is addressing computer-mediated technologies in the classroom, one is taking a stance that is decidedly not neutral.

Likewise, the field of Basic Writing cannot remain neutral; considerations of the use of technology with basic writers must align better with its overall values. The field would benefit from future research that considers basic writers' use of computer-mediated technologies in light of the discursive practices presented here, as well as research that further explores the technological hierarchies both inside and out of schools, and how they shape basic writers' literacy practices. Research about software programs that are targeted at basic writers and marketed to basic writing teachers is also important. Beyond developing research studies about the efficacy or comparison of such programs, we might consider the ways in which these programs contribute (or not) to an autonomous model of literacy in which 
software creators, instructors, and students disregard the social contexts in which literacies develop. As technology advances rapidly and students' increased use of mobile devices changes the ways we consider the access question, so too will ways of thinking about these technologies. As teachers and scholars, we must start to think about the ways we subscribe to-and struggle with-discourse so we might open up new possibilities in terms of using computer-mediated technologies with basic writers.

\section{Notes}

I. Bruce Horner capitalizes the term Basic Writing when referring to what he describes as a dominant discourse on basic writing whose meanings and forms are central to such works as Errors and Expectations, the Journal of Basic Writing, the I987 Sourcebook for Basic Writing Teachers and various bibliographies on basic writing (200). I refer to this discourse as Basic Writing to highlight both its institutional power and its selective representation of the wealth of practices and projects in teaching basic writing.

2. As defined by Bruce, those who take up the "aesthetic stance" see new technologies as "affording rich opportunities for creativity in electronic media. They talk of a paradigm shift as artists move from using the computer to recreate or reproduce art to accepting electronic representations per se as finished art" (29I). I have not found scholarship about computer-mediated technologies in Basic Writing to be much concerned with this stance, so I will not address it in this essay.

3. Mary Soliday critiques the "student need" argument and claims instead that remediation is more tied to institutional circumstances than student need.

4. For example, according to testimonials on its Web site, the Criterion program appears to have helped streamline the process for placement into remedial classes. Kristen Gray, lecturer at the University of Minnesota, writes “...it is a time-saver for instructors trying to quickly assess students' levels of writing ability without consuming inordinate amounts of time reading through essays and calibrating scores of other faculty and their students." In one case, using the program eliminated the remedial classes altogether. According to Dr. Robert Ellison of East Texas Baptist University: “The univer- 
sity used to offer remedial writing courses, but now all Comp One students write an essay using a Criterion prompt. Students who receive scores of 3 or less are required to take four tutoring sessions in which they work on their essays. At mid-semester they resubmit their essays" (Criterion case studies and testimonials).

\section{Works Cited}

Adler-Kassner, Linda, and Susanmarie Harrington. Basic Writing as a Political Act: Public Conversations about Writing and Literacies. Cresskill, NJ: Hampton Press, 2002. Print.

Bartholomae, David. Writing on the Margins: Essays on Composition and Teaching. New York: Bedford/St. Martin's, 2005. Print.

---. "Writing on the Margins: The Concept of Literacy in Higher Education." Writing on the Margins: Essays on Composition and Teaching. New York: Bedford/St. Martin's, 2005. Print.

---. "Teaching Basic Writing: an Alternative to Basic Skills." Writing on the Margins: Essays on Composition and Teaching. New York: Bedford/St. Martin's, 2005. Print.

Bartholomae David, and Anthony Petrosky. Facts, Artifacts, and Counterfacts: Theory and Method for a Reading and Writing Course. Upper Montclair, NJ: Boynton/Cook, I986. Print.

Barton, Ellen. "Interpreting the Discourses of Technology." Literacy and Computers: The Complications of Teaching and Learning with Technology. Eds. Cynthia Selfe and Susan Hilligoss. New York: Modern Language Association, I994. 56-75. Print.

Berhardt, Stephen, and Patricia Wojahn. "Computers and Writing Instruction." Research in Basic Writing: A Bibliographic Sourcebook. Eds. Michael Moran and Martin Jacobi. Westport, CT: Greenwood Press, I990. I65-90. Print.

Bernstein, Susan Naomi. “Social Justice Initiative for Basic Writing.” BWe: Basic Writing e-Journal 7.I (2008): n. pag. Web. I7 July 2012.

Boylan, Hunter. R. What Works: Research-Based Best Practices in Developmental Education. Continuous Quality Improvement Network, 2002. Print.

Brown, David G. "Hybrid Courses Are Best." Syllabus I5.I (200I): 22. Web. August 200I.

Bruce, Bertram. “Critical Issues: Literacy Technologies: What Stance 
Should We Take? Journal of Literacy Research 29.2 (I997): 289-309. Print.

Carpenter, Trudy G., William L. Brown, and Randall C. Hickman. "Influences of Online Delivery on Developmental Writing Outcomes." Journal of Developmental Education 26.I (Fall 2004): I4-35. Print.

Carter, Shannon. The Way Literacy Lives: Rhetorical Dexterity and Basic Writing Instruction. Albany: SUNY Press, 2009.

Crafton, Robert. "Promises, Promises: Computer-Assisted Revision and Basic Writers." Computers and Composition I3.3 (I996): 3I7-26. Print.

Crank, Virginia. "Asynchronous Electronic Peer Response in a Hybrid Basic Writing Classroom." Teaching Developmental Writing: Background Readings. Ed. Susan Naomi Bernstein. New York: Bedford/St. Martin's, 2002. 288-99. Print.

Criterion Case Studies and Testimonials. ETS Criterion. Web. 2007.

Cuban, Larry. Oversold and Underused: Computers in the Classroom. Cambridge, MA: Harvard University Press, 2001.

Cummings, Martha Clark. "Because We Are Shy and Fear Mistaking": Computer Mediated Communication with EFL Writers. Journal of Basic Writing 23.2 (2004): 23-48. Print.

DelPrincipe, Ann. "Paradigm Clashes among Basic Writing Teachers: Sources of Conflict and a Call for Change." Journal of Basic Writing 23.I (2004): 64-8I. Print.

Foucault, Michel. Discipline and Punish: The Birth of the Prison. New York: Vintage Books, I977. Print.

Gay, Pamela. "Questions and Issues in Basic Writing and Computing.” Computers and Composition 8.3 (I99I): 63-8I. Print.

Gee, James Paul. "The New Literacy Studies: From "Socially Situated" to the Work of the Social." Situated Literacies: Reading and Writing in Context. Eds. David Barton, Mary Hamilton and Roz Ivanic. London: Routledge, 200o. Print.

---. Social Linguistics and Literacies: Ideologies in Discourses. London: Taylor \& Francis, I996. Print.

Grabill, Jeffrey. “Technology, Basic Writing, and Change.” Journal of Basic Writing I7.2 (I998): 3I-IO5. Print.

Gunner, Jeanne. “Iconic Discourse: the Troubling Legacy of Mina Shaughnessy." Journal of Basic Writing I7.2 (I998): 25-42. Print.

Hawisher, Gail, and Cynthia Selfe. "The Rhetoric of Technology and the Electronic Writing Class." College Composition and Communication 42 (I99I): 55-65. Print. 
Haas, Christina. Writing Technology: Studies on the Materiality of Literacy. Mahwah, NJ: Lawrence Erlbaum Associates, I996. Print.

Horner, Bruce. "Discoursing Basic Writing." College Composition and Communication 47.2 (1996): I99-222. Print.

Horner, Bruce, and Min-Zhan Lu. Representing the "Other": Basic Writers and the Teaching of Basic Writing. Urbana, IL: National Council of Teachers of English, I999. Print.

Kish, Judith Mara. "Breaking the Block: Basic Writers in the Electronic Classroom." Journal of Basic Writing I9.2 (2000): I4I-55. Print.

Klages, Marisa A., and J. Elizabeth Clark. "New Worlds of Errors and Expectations: Basic Writers and Digital Assumptions." Journal of Basic Writing 28.I (2009): 32-49. Print.

Kress, Gunther. Literacy in the New Media Age. New York: Routledge, 2003. Print.

Lankshear, Colin, James Paul Gee, Michelle Knobel, and Chris Searle. Changing Literacies. Philadelphia: Open University Press, I997. Print.

Moran, Charles. "Computers and Composition I983-2002: What We Have Hoped For." Computers and Composition 20 (2003): 343-58. Print.

Pavia, Catherine. "Issues of Attitude and Access: A Case Study of Basic Writers in a Computer Classroom." Journal of Basic Writing 23.2 (2004): 4-22. Print.

Porter, James. Rhetorical Ethics for Internetworked Writing. Stamford, CT: Ablex Publishing, 2ooo. Print.

Reinking, David, Michael McKenna, Linda Labbo, and Ronald Kieffer, eds. Handbook of Literacy and Technology: Transformations in a Post-typographic World. Hillsdale, NJ: Routledge, I998. Print.

Ritchell, Matt. "Wasting Time is New Divide in Digital Era." The New York Times. 29 May 20I2. Web. 30 May 2012.

Romano, Susan. "The Egalitarianism Narrative: Whose Story? Which Yardstick?" Computers and Composition IO.3 (I993): 5-28. Print.

Rose, Mike. Lives on the Boundary: A Moving Account of the Struggles and Achievements of America's Educationally Underprepared. New York: Penguin Books, I989. Print.

Selfe, Cynthia. Technology and Literacy in the Twenty-first Century: The Importance of Paying Attention. Carbondale, IL: Southern Illinois University Press, I999. Print.

Smith, Cheryl C. "Technologies for Transcending a Focus on Error: Blogs and Democratic Aspirations in First-Year Composition." Journal of Basic Writing 27.I (2008). Print. 
Soliday, Mary. The Politics of Remediation: Institutional and Student Needs in Higher Education. Pittsburgh, PA: University of Pittsburgh Press, 2002. Print.

Stan, Susan and Terence Collins. "Basic Writing: Curricular Interactions with New Technologies." Journal of Basic Writing I7.I (I998): I8-4I. Print.

Stine, Linda. "Teaching Basic Writing in a Web-Enhanced Environment." Journal of Basic Writing 29.I (20IO). 33-55. Print.

---. "Basically Unheard: Developmental Writers and the Conversation on Online Learning." Teaching English in the Two-Year College 38.2 (2OIO): I32-48. Print.

---. "The Best of Both Worlds: Teaching Basic Writers in Class and Online." Journal of Basic Writing 23.2 (2004): 49-69. Print.

Street, Brian. Social Literacies: Critical Approaches to Literacy in Development, Ethnography and Education. London: Longman, I995. Print.

---. Literacy in Theory and Practice. Cambridge: Cambridge University Press, I985. Print.

Weedon, Chris. Feminist Practice and Poststructuralist Theory. Cambridge, MA: Blackwell, I987. Print. 


\title{
Interrogating Texts: From Deferent to Efferent and Aesthetic Reading Practices
}

\author{
Cheryl Hogue Smith
}

\begin{abstract}
This article offers a revised version of transactional reading theory to explain how students classified as basic writers tend to employ counterproductive reading and thinking processes that inhibit them from full participation in academic life. Louise Rosenblatt proposes that readers have two main positions or purposes in reading - the efferent stance, where readers focus on the information in a text, and the aesthetic stance, where readers focus on the experience they have with a text. This article describes a third, deferent stance of reading that many basic writers adopt when they defer their interpretations of texts to other readers or defer to the counter-productive emotions they experience during the process of reading difficult texts. Building on this theoretical frame, the article describes an instructional strategy employing a series of prompts that invite students to examine their own thinking as they read difficult texts and to focus more on what they don't understand than on what they do. The article concludes with reconstructions of classroom scenarios and a body of textual evidence showing how a carefully sequenced and controlled procedure for having basic writing students interrogate texts and themselves as readers can lead those students to become more engaged, authentic, and productive readers, writers, and participants in the academic community of a college classroom.
\end{abstract}

KEYWORDS: basic writing; reading/writing connection; transactional theory of reading; pedagogy

A 1999 study by Daniel Simons and Christopher Chabris describes an experiment where participants watching a video of six people passing a basketball were told to focus on one aspect of the video, for instance how many times the ball was passed among the three players wearing white shirts or the three players wearing black shirts. After watching the video, participants were asked if they saw anything unusual in the video, and only about $50 \%$ said they saw the person dressed in a gorilla suit who actually passed through the scene in the middle of the game. Simons and Chabris attribute the phenomenon of missing something that should be obvious to what they call "inattentional blindness" (IO60). This phenomenon refers to cases when we are so focused on a task at hand-in the experiment, counting the

Cheryl Hogue Smith is Associate Professor of English at Kingsborough Community College, City University of New York, where she serves as a Faculty Co-Coordinator for the Opening Doors Learning Communities and the Humanities Course Coordinator for the College Now program. In addition, she is a Fellow of the National Writing Project. She earned her Ph.D. in Language, Literacy, and Composition from the University of California, Santa Barbara, and focuses her research mainly on the teaching of basic writing.

(C) Journal of Basic Writing, Vol. 3I, No.I, 2OI2 
number of passes - that we miss something like a gorilla on the basketball court. As they explain, "observers are unlikely to notice" when something unusual is placed before them if their "attention is otherwise engaged" (IO7I).

This study makes me think of the way my students regularly read: Believing that most (if not all) reading tasks require "correct" responses, they are so intent on mining texts for "right" answers that they often miss the gorillas that might flash before them. This is not to say that reading for right or correct answers is always a barrier to learning or that seeing "gorillas" is always a path towards illumination. But just as the five-paragraph essay has its place in composition classes, where students can learn the structure of a deductively-reasoned paper before they learn to move beyond the limitations of that structure, so too must students move beyond reading-for-answers when they encounter complex and nuanced texts in composition classes. We want students to make intertextual connections, find subtleties in texts, listen and react to metacognitive whispers, engage emotionally with a text, read with multiple purposes, understand multiple interpretations, find gaps, and so on. In other words, we want students to read with a confidence that allows them to expand, rather than limit, their attention so they can be more sophisticated thinkers about texts.

I teach basic writing at a community college in Brooklyn, New York, where the students are as diverse a population as can be imagined in any urban setting. But one thing that seems to be common to most of my students is their struggle with interpreting texts that are typically assigned in college classes. For years, scholars have argued that many of the academic problems basic writers face are in large part due to the difficulty they have in reading and interpreting texts. As early as I976, Marilyn Sternglass was urging composition instructors to more actively become reading instructors in order to help their students succeed in college writing (382). In 2003, Sugie Goen and Helen Gillottte-Tropp concluded that the poor performance of a substantial number of students on the reading section of a placement test "accounts for their placement in basic writing classes, suggesting that students' difficulty constructing meaning from texts may be a significant source of their difficulty constructing meaning in texts" (9I, author's emphasis). Patrick Sullivan sums up the case in his insistence that if students are ever to be successful in college-level writing, they must first become successful in college-level reading (233). Behind all these arguments is the recognition that college students' ability to write is limited by their ability to read.

To that conception of the reading problem of basic writers, I would add the logically necessary corollary that the reading problem struggling 
students experience isn't confined merely to their analysis of assigned academic texts, but also to the texts of their own making. That is to say, the performance of writers necessarily depends heavily on their capacity to read their own emerging texts with sufficient interpretive insight to see where meaning remains undiscovered or inadequately articulated. Hence, as I have asserted elsewhere, "students can never outwrite their reading ability" (670). If we are ever going to create college-level writers, we must begin by creating college-level readers-both of others' texts and of their own. And to do that, we must help our basic writing students read as negotiators engaged in the construction of textual meaning, not miners of existing meanings, which is to say that we must help them overcome the "inattentional blindness" that consumes their thoughts when they read. We must teach them, in other words, to see the gorillas represented by their own responses, fleeting thoughts, emerging ideas, questions, and intuitions, and that means liberating their unproductively preoccupied attention.

\section{Basic Writers as Basic Readers}

Before I elaborate on what I am calling the "inattentional blindness" of basic writers, let me describe what typically defines their reading habits. In "Becoming a Strategic Reader," Scott Paris, Marjorie Lipson, and Karen Wixson argue that few basic writers know how to effectively "skim, scan, reread, integrate information, plan ahead, take notes, make inferences, and so forth" (795). Of these skills, Sheridan Blau emphasizes the particular importance of rereading: "One of the most powerful strategies available to us for reading difficult texts is the obvious strategy of rereading, which, it happens, is neither obvious nor frequently employed by many readers and is especially underemployed by those who think of themselves as (and generally appear to be) not very strong, or minimally competent, or unmotivated, or reluctant readers" (44). While all the strategies that Paris, Lipson, and Wixson catalog are important when readers interpret and analyze texts, the strategy of rereading is, as Blau describes, key for students to successfully interpret the texts we often assign. Many students come to our classes not understanding the writing process and the necessity for revision, and most do not realize that reading also requires revision through an act of slow and deliberate rereading. Moreover, for most basic writers the strategy of rereading carries with it a stigma that connotes deficiency or incompetence because many associate "rereading" only with the struggles of those who can't read. My own students often see rereading much like they do a visit to any writing 
center: If they go to a tutor, clearly there is something "wrong" with them or their writing. Ironically, for basic writers, the very things that can help all students succeed are typically seen as forms of punishment and evidence of failure. Thus, the need for rereading seems to trigger in basic writers all the feelings of inferiority and imminent failure that scholars like Shaughnessy and Rose brought to our attention so many years ago.

To counter basic writing students' reluctance to reread, we might first begin by helping them understand that even the most competent readers of college-level texts need to negotiate and construct meaning, which entails a significant amount of rereading. Linda Flower, in The Construction of Negotiated Meaning, speaks of how reading and writing are meaning-making processes, where readers are certain to find in texts "alternative goals, constraints, and possibilities" with which they must negotiate (2). Similarly, in her transactional theory of reading, Louise Rosenblatt argues, "Every reading act is an event, or a transaction involving a particular reader and a particular pattern of signs, a text, and occurring at a particular time in a particular context. Instead of two fixed entities acting on one another, the reader and the text are two aspects of a total dynamic situation" ("Transactional" I063). Or as Mikhail Bakhtin puts it, a "text is not a thing" in itself; rather, it is always under construction (IO7). All these accounts of how readers negotiate meaning imply an engaged, active, meaning-making reader who reads slowly and recursively.

One could argue, however, that basic writers are, in fact, active readers, with their activity focused on mining texts for "right" answers. Stephen Norris and Linda Phillips pointed out long ago that struggling students often search for the predetermined and fixed meanings that they believe we, as teachers, are looking for (408-409) - a search that Carol Dixon and Denise Nessel describe "as a meaning-finding process" (5). While this meaningfinding process does subvert the rhetorical and interpretive skills students need to engage thoughtfully with texts, it also shows that students have the capacity to read with a focused attention-a skill that, if honed in more productive ways, can transfer students' focus from a scavenger hunt within a text to their transaction with that text. And in so doing, they will develop reading habits that will help them engage with texts more meaningfully.

A similar but related counterproductive reading habit that students sometimes exhibit is jumping on the bandwagon in support of the interpretation they think is the most valued by the class leaders and/or instructor. Students who defer to other's interpretations often write papers that parrot class discussions rather than reflect their own understanding of a text. As 
Blau describes this phenomenon, students "behave like consumers of literary interpretations rather than the producers of them" (20). So if we can show students that actively reading (and rereading) texts can help them to better negotiate meaning, we can lead students to see that they needn't buy someone else's interpretation of texts because they themselves already have the capacity to be "producers of them." But until these students understand the power they hold with texts, they are in danger of holding on to the belief that texts have a predetermined meaning that they are obliged to extract, one that successful students know how to find. Hence, our students read with the purpose of discovering what they think of as the correct information and/or deferring to those who seem to have found it.

\section{Reading with Purpose}

As one of the seminal theorists about the importance of purpose in reading, Rosenblatt classifies the full range of possible reading purposes into two stances that she designates the "efferent" and the "aesthetic." She asserts that readers always adopt a stance while they are reading, which influences their transactions with texts during the reading process. She explains that efferent and aesthetic stances "reflect the two main ways of looking at the world" in that the efferent stance deals more with "the cognitive, the referential, the factual, the analytic, the logical, the quantitative aspects of meaning," while the aesthetic stance deals more with "the sensuous, the affective, the emotive, the qualitative" ("Transactional" I068). Rosenblatt is clear that texts themselves are neither efferent nor aesthetic; instead, our purpose for reading texts determines which stance we assume. She explains that the efferent stance entails "a process of more stringent narrowing of the focus of attention," while the aesthetic stance demands more of "an opening of the shutter, so to speak, to admit a broader field of awareness" ("On the Aesthetic" 23). According to Rosenblatt, when we read texts in order to extract information-like facts in a biology text or directions in a product's user manual-or to pay attention to the structural form or the logic of an argument, we are purposefully narrowing our focus to find specific information. On the other hand, when we are reading aesthetically, we allow our minds to open and experience our transaction with the text both cognitively and affectively. She adds that we choose a stance based upon how we think the texts need to be read.

Rosenblatt's discussion about stances presupposes a fairly sophisticated level of metacognitive awareness on the part of readers, an awareness 
of their own purposes. And this kind of awareness, Richard Vacca argues, typifies the practice of successful readers who are strategic in their reading process, actively monitoring their thinking as they read (8). Rosenblatt explains that as we read, we move back and forth between the two stances, depending on the signals our metacognitive monitors emit. For example, as readers of Shakespeare's Henry IV plays, we can be fully engaged in the emotional drama of the play while acquiring historical information about the reign of Henry V. In the end, Rosenblatt believes that readings can fall anywhere on the continuum between the two polar stances and argues that most readings probably fall somewhere in the middle of the spectrum ("Transactional" Io68).

In addition to Rosenblatt's two stances, I want to argue that there is, in fact, a kind of tertium quid-a pseudo-literate third stance that I'll call the "deferent stance." The deferent stance is like the efferent stance in that it is more of a "stringent narrowing of the focus of attention" (Rosenblatt "On the Aesthetic" 23) wherein students concentrate merely on finding "correct" answers, including answers that sometimes aren't there for them to find. In so doing, they create for themselves an "inattentional blindness" (Simons and Chabris) that prevents them from encountering a text with anything resembling free attention that would otherwise allow them to fully engage with that text. So instead of discovering how intertextual relationships, subtleties, and multiple interpretations affect the possible meaning and therefore interpretation of a text, they limit their engagement through their narrowly defined purpose. Also, for many struggling readers, the deferent stance includes the "affective" or "emotive" aesthetic_or more accurately anesthetic-aspect of reading in that reading becomes an emotionallynumbing prospect for readers who anticipate a negative outcome and often quit at the first sign of difficulty (Vacca and Padak).

Some basic writers who are deferent readers often give up on demanding texts because they believe the texts are too hard for them; they assume that when they have difficulty understanding challenging texts, their struggle to understand must be attributable to a deficiency in their reading ability, not in the fact that some texts are just difficult and require patience, sustained focus, and persistence to understand (Blau). Blau makes the case that only challenging texts are worth reading because they teach us difficult concepts that we don't already know, but we have to be willing to face the confusion and insecurity of not knowing (24). Successful readers know how to metacognitively face the confusion and insecurity of reading complex texts without internalizing the sometimes destructive feelings that accom- 
pany the process of working through the confusion. Basic writers, however, often struggle with confusing texts because they do internalize and defer to the negative feelings, turning an intellectual endeavor into an emotionally defeating one. To this end, I would argue that instead of embracing confusion (Blau), basic writers embrace their emotions, essentially severing their link to the metacognitive monitors that could otherwise help them identify problems within the text and then figure out how to address those problems.

If students are ever to write successfully in the academy, they must metacognitvely read difficult and complex texts that will initially and inevitably require them to experience and endure confusion, at least for a while. In many ways, metacognitive reading is an exercise that allows for gorilla sightings, as long as readers are willing to listen to the cues. But as long as struggling readers think confusion represents some insufficiency in them rather than difficulties located in the text (Blau), they will either retreat entirely from the challenges posed by difficult texts or continue to read as supplicants or lost travelers hoping to stumble upon the "correct" answer that they would never be able to find otherwise.

\section{Interrogating Texts}

One way that I have had success in helping students shed their deferent approach to reading is by teaching them how to interrogate a text, which is to say, how to understand a text by focusing on questions instead of answers. While I am grateful to Robert Probst, whose "Dialogue with a Text" gave me the basic format for the exercise I am about to describe, I am deeply indebted to the workshop practices of Sheridan Blau, who profoundly affected the way I now teach reading in my basic writing classes, even though his discussions-like Rosenblatt's-revolve around the teaching of difficult literary texts, which we may not immediately associate with basic writing classrooms. The "Interrogating Texts" exercise I use in my classes (see Appendix A) combines the tactics of both Probst and Blau by using open-ended template questions that students can apply to any text as they reread and reflect upon the more difficult aspects of that text. The key here is that students are instructed to investigate not what they do understand, but to focus on what they don't, which is a fundamental shift in the thinking of students who think that their only job as readers is to know right answers.

For the exercise, students are placed into small groups where they individually write their responses to open-ended questions about their experience of the text they are reading. In order for "Interrogating Texts" to 
work, students must follow the directions, which are listed on the exercise handout and which I also give orally, and I monitor their groups to make sure they are following them. These are the oral instructions I provide:

(I) Read the first direction/question.

(2) Answer the question or respond to the direction; you must write your responses. Remember that any questions you have of the text constitutes an acceptable and valuable response.

(3) Wait patiently for your group members to write their responses. Do not move ahead to other questions; your discussions with your group members may influence subsequent responses.

(4) Read aloud your responses; you cannot say what you intended to write, but must read what you actually wrote.

(5) Discuss your responses only after everyone has read their writing; do not discuss any of the responses in between each group member's reading.

(6) After everyone has read, discuss all you want.

(7) After your discussions for each question, write down anything you just learned from your group that you hadn't thought of before you discussed it.

(8) Move to the next question/direction.

These directions force students to first write, then read, and finally discuss their responses. In other words, they cannot hide what they actually think about a text because they are not allowed to discuss the reading until the entire group has read their responses. Inevitably, students have different responses, and students learn very early on to respect the various answers and recognize the validity of the varying perspectives. By not being able to defer to or parrot someone else's response, they learn to trust their own ideas; for some, this is the first time they have realized that their thinking has merit.

I first use "Interrogating Texts" with a reading that isn't too difficult; this way, I don't make the exercise any more anxiety inducing than it already is, given that students must read their writing aloud. But I also use a less-demanding text to help students become accustomed to the way the "Interrogating Texts" process works. Before I introduce this assignment to my class, I spend a couple of weeks on what it means to read closely (with a dictionary in hand), so my students have learned to deal with difficult vocabulary when reading texts. The students are required to read the texts that I assign prior to class, giving them as much time as they need to read. 
Therefore, when they begin "Interrogating Texts" in my class, their "first" read is actually their second (or, dare I hope, their third or fourth).

The first instruction requires students to summarize and paraphrase, which is fundamental for all students to master since they will usually need to summarize and paraphrase any text they write about. These are often difficult skills for basic writers to master and when they first do "Interrogating Texts," their summaries for the first question are sometimes quite short. Still, I've never encountered a student who was unable to write at least a sentence about what he has read, which is all students need to participate. Students in groups almost always choose to highlight different aspects of the texts they are summarizing and paraphrasing, so when students discuss these differences in their groups (after they've all read their responses), they begin to discover that multiple interpretations are not only possible, but also likely and probably advantageous. And it's this discovery that is the first step towards shedding their belief that they need to find the one, fixed interpretation that their instructor is looking for. Early last semester, the participants of one group all simultaneously jerked their heads up toward me with a look that suggested they had done or said something wrong; I went over to their group to see what happened. One student hesitantly asked, "What if we all said this reading is about something different?" I replied, "Great! Talk about what you found!" They looked perplexed but proceeded to talk and ultimately saw the validity of multiple interpretations as a path to increased understanding of a text that, initially, is confusing.

This scenario happens often: Students discover that through their discussions, they-together as a group—come to a better understanding of a text's difficulties, which have suddenly become interesting. Incidentally, they also learn that it's impossible to fully summarize or paraphrase a text they don't yet understand and that it's okay and even productive to be confused about the text as they discuss their paraphrases and identify their confusions. When they see that their group members are also confused or that they have different responses, students begin to realize that reading isn't about finding the "right" answer and that they need not defer to others' interpretations.

The second "Interrogating Texts" direction asks students to reread the text and then to underline the one sentence they felt was "most important to the meaning of the entire piece." To do this, students must be able to reflect upon their own individual experience of the text well enough to explain why they chose that one sentence. The discussion that already took place after the first summary directive sets them up to answer this question, because they have already debated their different constructions of what the text is 
about. So the discussion after the first question, combined with yet another reading of the text, are ample preparation to help students make the leap from summary to analysis. After all, underlining the one sentence that they feel is the most important to the meaning of the entire piece and then explaining why they chose that one sentence is an act of analysis. Sometimes students underline different sentences, and sometimes they underline the same ones; it really doesn't make a difference for this exercise because the analysis of why they chose the sentence reveals their individual interpretive and reflective thinking, and it's in that discussion of why that students continue to learn from each other while simultaneously beginning to believe in their ability to transact and negotiate with texts.

The third and fourth questions are designed to show students the value of rereading (again) and, as Blau often says in workshops, to "embrace confusion" by focusing on the questions they still have about the text. The discussions students have about what they still don't understand tend to be some of the most productive because those discussions so dramatically demonstrate to students how interpretation isn't about finding already known answers and how their own questions about meaning are almost always the most useful and reliable avenue to a deeper reading of texts.

Thus, "Interrogating Texts" works for several reasons. First, students are constantly rereading and in that process revising their interpretations every time they read the text, thereby learning the power of rereading as a strategy for dealing with difficult texts and as a productive alternative to the temptation to give up when faced with especially challenging reading tasks (Blau 44). Second, by reading their responses before any discussion begins, students discover the value of their own interpretations to the thinking of other readers as well as the value of alternative interpretations to their own thinking. These discussions help students learn that having ideas and putting them out for the world to see isn't as scary as they think and can even be productive, especially when people may disagree with their responses. Third, by shifting the focus to what confuses them, instead of focusing on a single answer that they think they're supposed to find, students place their attention on their own experience of the text rather than on a right answer. Last, they learn that they are capable readers and that they can support their interpretations of texts with evidence from those texts (as the exercise asks them to do), especially in negotiations with readers who disagree with them. 


\section{Interrogating Texts in Practice}

The most memorable experience I've had using "Interrogating Texts" was in a basic writing class when students were reading Jo Goodwin Parker's "What is Poverty?" - an essay by a woman who lives in squalor with her children and who vividly describes her life of poverty. When students first read this essay, they didn't know that I was going to pair it with a chapter in Barbara Ehrenreich's Nickel and Dimed, which details the author's social experiment of working in minimum wage jobs. As students would eventually learn, the writing assignment would ask students to become Goodwin Parker in order to evaluate Ehrenreich's view of living in poverty:

Pretend that you are Jo Goodwin Parker and that you have just read Ehrenreich's "Serving in Florida." Then, in a well-developed essay, explain your reaction to Ehrenreich's chapter, describing whether or not you think she effectively explained in "Serving in Florida" what it is like to work a minimum-wage job and live the life of a relatively poor person. In other words, you are going to compare your life as Goodwin Parker to the life Ehrenreich describes in her narrative to show whether Ehrenreich understood what it was like to live an impoverished life.

To prepare students for this paper, I assigned Goodwin Parker before Ehrenreich, and I gave them "Interrogating Texts" to use with Goodwin Parker's text. As I always do when students are working on this exercise, I moved through the class and eavesdropped on their discussions. At first the students' responses were not unusual. From the very first question, the students started to realize that Goodwin Parker's text could be interpreted in multiple ways. In one group of three young women, the first focused on Goodwin Parker's sad circumstances, another criticized the government, and the third was critical of Goodwin Parker's choices. The three dissimilar summaries elicited intriguing and lengthy discussions. The students also started listing the questions they had: "Where is she?" "How young is she?" "Why did she not give her kids up for adoption?" and "How can I help?"-all of which are important questions to ask about the text.

For the second "Interrogating Texts" step, this same group chose three different sentences to discuss: "Poverty is an acid that drips on pride until all pride is worn away" (33), "I knew my husband was leaving the day he left, but there were no good-bys between us" (32), and "The poor are always 
silent" (34). Each student was able to discuss why she thought this sentence was the most important in relation to the entire text, and again the conversations were enlightening to the members of the group because each student placed the "blame" for Goodwin Parker's circumstances on different people or forces in her life.

It was during the third question that something unusual happened in class. Chip, ${ }^{\mathrm{I}}$ from a different group, stood up and started lifting his desk a few inches off the floor and loudly banging it on the ground. He was so excited about the debate between Andrew and Tia that he couldn't contain his emotions. Even though Chip's group was only on the second question, the group I was watching stopped their discussions about the third question and became participants in what turned into an animated class debate. Chip, Andrew, and Tia became discussion leaders, of sorts, as they (mostly) respectfully challenged each other's thinking. Andrew believed that the impoverished mother in the text had a responsibility to give her kids away, while Tia accused the husband of desertion and said the mother should keep her kids as long as she could. It became a debate about male-female responsibility in society as a whole. I watched as the two sides used evidence from Goodwin Parker's text, other texts, and their own lives to address this problem that Goodwin Parker only minimally touches upon. Here they were, making intertextual connections, finding subtleties, reading (and discussing) metacognitively, understanding multiple perspectives, and finding gaps in the text; in essence, they were seeing some gorillas. I sat back and watched as the entire class became immersed in a discussion I could not have orchestrated if I had tried.

It occurs to me now that what I witnessed was an act of basic writers emotionally engaging with and experiencing a text. I had often seen how "Interrogating Texts" helped move students away from the deferent stance of reading in that they stopped looking for predetermined meanings in texts (the skewed efferent stance), but I could never really gauge how it helped move students away from the negative emotions they often associate with learning (the anesthetic stance), other than seeing that they were in no distress as they discussed the texts. But in that class session on "What is Poverty?" — with Chip banging his desk and emotions flying through the room-I could see that the discussions surrounding this essay helped these students experience what engaged, active learning feels like. They were combining this text with their lived experiences, which connected them to the text in such a way that they could not hide their enthusiasm or their enjoyment of the academic debate. These students showed no signs of deference; in fact, they showed an emotional and intellectual engagement with the text. Before my eyes, these students 
were experiencing Rosenblatt's efferent and aesthetic stances, moving to and fro on the continuum as they shared their thoughts and feelings about the text.

After about fifteen minutes of heated debate, the arguments died down and the groups went back to their discussions. The group I was watching moved on to question four. Below are samples of Monica's, Yvette's, and Melinda's answers to the fourth set of prompts: "What questions does this essay leave you with? What do you wish you had more information about? What do you still not quite understand in the text?"2

Monica: I think the first question the text leaves me with is how old is the girl? She always says she is very young compared to how old she looks.

Yvette: What's up with our country? How can someone get valuable help and life a healthy life? How old are you? I'm curious to know how old she was when she married. How come she doesn't take her children somewhere or even adoption?

Melinda: Why didn't she avoided the problem. She should of gone to school and done something instead of getting married. I would wish to know why she went through that when she could have avoided it.

The answers to the above "Interrogating Texts" questions cannot begin to capture the intellectual or emotional depth of the conversations that happened during these group discussions. What we can see are the various kinds of questions students were asking, from concrete ("How old is the girl?") to interpretive and analytical ("Why didn't she avoided the problem?" and "What's up with our country?"). There's even evidence in Yvette's response that the larger class discussion influenced her thinking about the subject ("How come she doesn't take her children somewhere or even adoption?"). In this group, the students were asking questions within and beyond the text, and two of the three were trying to solve the larger social problems (child services and education) that their experience with the text evoked. In short, these students were thinking about the text and the problems of this text that they would ultimately write about.

Because I wanted to hear what these students thought of this exercise, I also asked an additional question: "In what ways did the discussions of these questions with your partners help you view the texts differently?" 
Monica: They brought up different points of views I didn't consider when I wrote my answer. Different emotions writing techniques were used to persuade us all in different ways of talking about the text.

Yvette: Ilike to hear other people's thoughts. I see how sometimes we all have the same idea except one or two people will come up with something totally different than what I was thinking. Which is pretty cool.

Melinda: In the beginning I was like oh my gosh but then I'm thinking she could have avoided it by not doing the things she did. In case other people who go through poverty because something happens you know!

Monica's and Yvette's answers to the last question are the most revealing, for both students saw alternate viewpoints that made them think in new ways about the text. This is not to say their opinions changed (or didn't), but that they recognized others had dissimilar yet valuable thoughts, and by implication, their own differing thoughts were also valuable. Melinda's answer, I think, represents how she did change her opinion about the essay. She didn't quite answer the question I asked, but she seemed to be saying that at first she was taken in by Goodwin Parker's descriptive plight before her group members helped her to see that Goodwin Parker might have some culpability in her own destiny. This isn't to say she began parroting her group members; instead, she learned from her group members through a process of negotiation that advanced her own interpretation. In addition, Monica touches upon the affective, aesthetic aspect of this exercise: "Different emotions writing techniques were used to persuade us all in different ways of talking about the text." What Monica is referring to here is the pathos that Goodwin Parker uses to manipulate her reader's emotions-with the descriptions of poverty that are almost too vivid to stomach-and Monica's response demonstrates her awareness of the emotional engagement she and her group members had with this text. It is virtually impossible not to viscerally experience Goodwin Parker's text, but rarely do students understand or so clearly explain that the pathos of Goodwin Parker's argument affects the different ways readers will interpret her text.

As I listened to the conversations in the room (but mainly of this one group), I noticed that once students started talking about what they didn't understand in the essay, they began to look at their confusion as a product 
of the text, not as evidence of a deficiency in themselves as readers. And they started listening to the varied and warranted interpretations that their group members (and in one case, the whole class) had about the essay. They started to believe and understand that they were capable readers, they were producers of plausible interpretations, and they could emotionally engage with a text in positive ways-all of which helped them begin to reject the deferent stance they might otherwise be inclined to take. Of course, one participation in this exercise does not automatically transform students' stances from deferent to efferent or aesthetic (or both), but it does help them begin to see that there is more to reading than getting the correct answer-that the process of discovery is valuable in and of itself and that questions and even confusion are pathways to richer and more illuminating ideas about a text. As both Monica and Yvette attest, students also learn the value of multiple interpretations.

Incidentally, every student in this class who participated in the "Interrogating Texts" exercise was able to effectively adopt the persona of Goodwin Parker in order to critique Ehrenreich's experiment. In the one and a half hours that students had to write this essay (as an in-class essay), many explained the significance of the differences and similarities between Goodwin Parker and Ehrenreich, which was not a requirement of the prompt, and I can't help but think that their thorough understanding of the Goodwin Parker text contributed to the added layer of analysis that many students included.

I've used "Interrogating Texts" in numerous classes, most recently in a freshman composition class that was reading Edward Dolnick's The Forger's Spell, a book that details how a mediocre Dutch painter made millions during World War II selling forged Vermeer paintings to national museums and high-ranking Nazis. Jody, a student in this class, asked, "Are we going to be doing one of these for every part of the book?" The book is divided into five parts, and for each part I chose short but crucial chapters to use in an "Interrogating Texts" exercise in order to help students understand the nuances of Dolnick's text and to get them ready to answer the question for their final paper: "Why did Hitler and Goering covet Vermeer's paintings?" We were only on Part II of the book when she asked her question, so I hesitantly answered, "Yes," expecting that Jody would complain about the monotony of doing the same exercise day after day. She surprised me with her response: "Good! Because doing this really helps me understand what is going on in the book." 


\section{Through the Mist}

While I stand behind this exercise as one that I think breaks basic writers of counter-productive reading habits, I in no way mean to suggest it is the only way to teach reading; it is just my way of teaching difficult, complex, and problematic texts to a group of students who have continually faltered in reading and writing tasks because they adopt a deferent stance when reading. "Interrogating Texts" helps basic writers ignore that deferent stance by liberating their attention from predetermined and fixed meanings in texts and shedding the counterproductive emotional responses they might otherwise have towards reading and rereading. It helps students identify themselves as readers as they learn the value of pushing through confusion caused by difficult texts.

We have to acknowledge, however, that some interpretations of texts can be, in fact, off the mark, which should not be confused with "right" versus "wrong" answers. Glynda Hull and Mike Rose discuss the notion of "misreading" in their description of a Trinidadian/Jamaican student's "misreading" of a poem: Robert, who doesn't understand the middle-class use of the word "shack" in a poem because a "shack" from his parents' homelands isn't a hovel, interprets the poem in such a way that Rose classifies it as a clear misreading of the text. Hull and Rose conclude that misreadings often come from logical places, but that doesn't help those students who struggle with their academic confidence as they read. We have all misread texts because, like Robert, we lack some piece of relevant cultural information, but we are usually happy to discover our mistake and correct our reading, constructing a more comprehensive and internally consistent interpretation of the text. For basic writers like Robert, however, such discoveries are hardly welcome because although they can logically support their mistaken interpretation with evidence from the text (which with their limited cultural knowledge is valid evidence), the final verdict of their misreading is added proof of their "incompetence" as readers unable to find the "correct" answers that others were able to find. Situations like this exacerbate basic writers' tendency to read deferently; even though we continually preach that there are no "right" and "wrong" answers, they are confronted with proof that they are, in fact, wrong in their interpretations and should therefore defer to others in the class. Exercises like "Interrogating Texts" can help students learn to discover as a group the normative readings of texts and can show them, particularly through the discussions, how a "misreading" can be both logical and literate, yet mistaken at the same time. And through those nuanced discussions, 
students can develop the confidence to understand that sometimes misreadings happen, and revising interpretations based upon missing information is not a matter of deference, but a necessary part of any reading process.

As Wolfgang Iser suggests, there are infinite numbers of readings for texts, which means there are infinite numbers of interpretations. Our students need to learn that their interpretations will fluctuate depending on how often they read and discuss texts, and they need to have a safe place to feel passionately about and discuss all of their interpretations, even those that might be off the mark. The point is for students to become comfortable with their own interpretations, whether they are a little or completely different from their classmates. With faith in their ability as readers and interpreters of texts, they need to welcome any challenge to those interpretations and believe in their capacity to revise their interpretations when necessary. Yet they also need to defend-without fear-their conviction when they think their atypical interpretation is warranted.

In the end, regardless of how we each accomplish it, we must help our students shed the deferent stance that is created by their inattentional blindness and/or their willingness to take on other's interpretations. By shifting their focus from their insecurities to the transaction they experience with difficult texts, they will learn to see through the mist in order to catch glimpses of the gorillas that appear before them-even if they see those gorillas as chimpanzees or orangutans or even if they, at first, mistake them for lions.

\section{Acknowledgements}

I wish to thank Cheryl C. Smith for her extraordinarily helpful responses to several drafts of this article, and I, of course, wish to express my gratitude to the students who inspired it in the first place.

\section{Notes}

I. All student names in this article are pseudonyms, and student work is used with permission.

2. Student answers have not been edited from the original. 


\section{Works Cited}

Bakhtin, Mikhail. "The Problem of the Text in Linguistics, Philology, and the Human Sciences: An Experiment in Philosophical Analysis." Speech Genres and Other Essays. Austin: U of Texas P, I986. I03-3I. Print.

Blau, Sheridan. The Literature Workshop: Teaching Texts and Their Readers. Portsmouth: Heinemann, 2003. Print.

Dixon, Carol N., and Denise D. Nessel. Making Meaning: Directed Reading \& Thinking Activities for Second Language Students. Englewood Cliffs, NJ: Alemany Press, I992. Print.

Dolnick, Edward. The Forger's Spell: A True Story of Vermeer, Nazis, and the Greatest Art Hoax of the Twentieth Century. New York: Harper Collins, 2008. Print.

Ehrenreich, Barbara. "Serving in Florida." Nickel and Dimed: On (Not) Getting by in America. New York: Henry Holt and Company, 200I. II-49. Print.

Flower, Linda. The Construction of Negotiated Meaning: A Social Cognitive Theory of Writing. Carbondale: Southern Illinois UP, I994. Print.

Goen, Sugie, and Helen Gillotte-Tropp. "Integrating Reading and Writing: A Response to the Basic Writing 'Crisis." Journal of Basic Writing 22.2 (2003): 90-II3. Print.

Goodwin Parker, Jo. "What is Poverty?" America's Other Children: Public Schools Outside Suburbs. Ed. George Henderson. Norman: U of Oklahoma P, I97I. 30-34. Print.

Hull, Glynda, and Mike Rose. “The Wooden Shack Place': The Logic of an Unconventional Reading." College Composition and Communication 4I.3 (I990): 287-98. Print.

Iser, Wolfgang. “The Reading Process: A Phenomenological Approach.” The Implied Reader. Trans. David Henry Wilson. Baltimore: Johns Hopkins UP, I974. 274-94. Print.

Norris, Stephen, and Linda M. Phillips. “The Relevance of a Reader's Knowledge within a Perspective View of Reading." Journal of Reading Behavior 26.4 (I994): 39I-4I2. Print.

Paris, Scott, Marjorie Lipson, and Karen Wixson. "Becoming a Strategic Reader." Theoretical Models and Processes of Reading. 4th Edition. Eds. Robert Ruddell, Martha Rapp Ruddell, and Harry Singer. Newark, DE: International Reading Association, I994. 788-8Io. Print.

Probst, Robert E. “Dialogue with a Text.” English Journal 77.I (I998): 32-38. Print.

Rose, Mike. Lives on the Boundary: The Struggles and Achievements of America's 
Underprepared. New York: The Free Press, I989. Print.

Rosenblatt, Louise M. "On the Aesthetic as the Basic Model of the Reading Process.” Bucknell Review 26.I (198I): 17-32. Print.

---. "The Transactional Theory of Reading and Writing." Theoretical Models and Processes of Reading. 4th Edition. Eds. Robert Ruddell, Martha Rapp Ruddell, and Harry Singer. Newark, DE: International Reading Association, I994. I057-I092. Print.

Shaughnessy, Mina. Errors and Expectations: A Guide for the Teacher of Basic Writing. New York: Oxford UP, 1977. Print.

Simons, Daniel J., and Christopher F. Chabris. "Gorillas in Our Midst: Sustained Inattentional Blindness for Dynamic Events." Perception 28 (1999): I059-I074. Print.

Smith, Cheryl Hogue. "Diving In Deeper: Bringing Basic Writers' Thinking to the Surface." Journal of Adolescent and Adult Literacy 53.8 (2010): 668-676. Print.

Sternglass, Marilyn S. "Composition Teacher as a Reading Teacher." College Composition and Communication 27.4 (1976): 378-382. Print.

Sullivan, Patrick. "What Can We Learn About 'College-Level' Writing from Basic Writing Students? The Importance of Reading." Eds. Patrick Sullivan, Howard Tinberg, and Sheridan Blau. What is "College-Level" Writing? (Vol. 2) Urbana, IL: National Council of Teachers of English, 20I0. 233-253. Print.

Vacca, Richard T. "From Efficient Decoders to Strategic Readers." Educational Leadership 60.3 (2002): 6-II. Print.

Vacca, Richard T., and Nancy D. Padak. "Who's at Risk in Reading?" Journal of Reading 33.7 (1990): 486-88. Print. 


\section{Appendix \\ INTERROGATING TEXTS}

Please read the essay assigned for today, and take a few minutes to reflect on it. Then begin answering the questions. Take as much time as you need for each question. Reread the text as necessary. The goal is not to finish, so if your group gets hung up on one question for a long time, don't worry. Just keep the discussion going. (You may need extra paper for enough space to answer.)

I. Summarize/paraphrase the text you just read. Do not look at the text as you do this. After you paraphrase the text, write down any questions that this text leaves you with.

**Wait for your group members to finish writing their answers, and then discuss all of your answers before moving on.

Write down anything you just learned from your group that you hadn't thought of before you discussed it.

\section{Reread the text, and underline the one sentence that you think} is most important to the meaning of the entire piece. Explain why you think this one sentence is the most important sentence in the piece. If you found some of this text difficult, mark what you think were the most confusing parts, and discuss these with your group.

**Wait for your group members to finish writing their answers, and then discuss all of your answers before moving on.

Write down anything you just learned from your group that you hadn't thought of before you discussed it.

\section{Reread the text once again, and make note of anything interest-} ing or important that you may not have noticed before, including any new questions you may have. What did you discover during this reading that you didn't notice before? How do these new discoveries make you now view the text? 
From Deferent to Efferent and Aesthetic Reading Practices

**Wait for your group members to finish writing their answers, and then discuss all of your answers before moving on.

Write down anything you just learned from your group that you hadn't thought of before you discussed it.

4. What questions does this essay leave you with? What do you wish you had more information about? What do you still not quite understand in the text?

${ }^{* *}$ Wait for your group members to finish writing their answers, and then discuss all of your answers before moving on.

Write down anything you just learned from your group that you hadn't thought of before you discussed it. 


\title{
Steep Houses in Basic Writing: Advocating for Latino Immigrants in a North Georgia Two-Year College
}

\author{
Spencer Salas
}

ABSTRACT: Recounting the controversy surrounding a town hall meeting on "illegal" Latino immigration at a two-year college in North Georgia, this ethnographic narrative details the aftermath that ensued and its consequences for an ESL basic writing instructor. Fallout included the potential loss of her job, the rumored reallocation of a $\$ 5$ million earmark for the college's student center, and a death threat phoned into the Dean's office. Theorizing the disciplinary insularity of contemporary activist basic writing scholarship, the article calls for an expansion of conceptualizations of political engagement in relation to Generation I.5 and, specifically, Latino immigrants' physical access to higher education.

KEYWORDS: Dream Act; immigration; Generation I.5; Latinos; Basic Writing

A large part of what Taylor St. John ${ }^{\mathrm{I}}$ did as ESL Learning Support program coordinator was to "interpret" ESL students to the faculty of Sweet Water College in Hogg Mountain, Georgia. Or, as Taylor put it, she often found herself "trying to explain to them (the faculty), in a sympathetic way, issues that they (ESL students) may have." For example, in Spring 2006, María Jesús was having a terrible time in Psychology Ior because of the professor's preference for un-subtitled videos that he did not allow students to check out. Taylor suspected that her colleague had lost several in the past and that he no longer trusted students to take them home. Taylor reassured María Jesús that she would talk to him. They would come to some sort of agreement-Taylor was certain.

In two-year college communities, basic writing instructors such as Taylor St. John are often called on to be advocates for transnational children of immigration-negotiating their needs with individual colleagues and the greater community and reassuring their students that others will understand

Spencer Salas is Assistant Professor in the Department of Middle, Secondary, and K-I2 Education at the University of North Carolina at Charlotte. He has served with the Fulbright Program in Romania, Guatemala, and South Africa and, in 20o8, was named a "New Voice among Scholars of Color" by the National Council of Teachers of English. His writing has appeared in TESOL Journal, Bilingual Research Journal, Action in Teacher Education, and Community College Review. His most recent work is as co-editor of Vygotsky in 2Ist Century Society: Advances in Cultural Historical Theory and Praxis with Non-Dominant Communities, published by Peter Lang.

(C) Journal of Basic Writing, Vol. 3I, No.I, $2 \mathrm{OI} 2$ 
their challenges and their potential. I have written of Taylor and her colleagues and the dilemmas that mediated their professional subjectivities as basic writing faculty. These ranged from the institution's excruciatingly narrow understanding of what it meant to be ready for college; to the ambiguous relationship between ESL Learning Support and remediation; to the program's torturous exit procedures; to the college's emerging four-year aspirations; to the personal dilemmas that the instructors negotiated alongside their teaching (Salas "Roberta"; Salas "Teaching and the Dilemma of the Personal"; Salas "Something That You're Proud of "). However, of the various tensions of being an ESL Learning Support faculty member, the highly contentious issue of immigrants' right to access a postsecondary education in the state of Georgia was central to Taylor and her colleagues' understandings of who they were professionally and why their work mattered.

In this "tale from the field" (Van Maanen), I recount the controversies surrounding a town hall meeting on the topic of "illegal" immigration in North Georgia. My intent in relating the events that follow is to question the insularity of some activist strands of contemporary basic writing scholarship. I argue that that a discipline historically committed to open admissions must engage more explicitly with state legislation aimed at excluding Latino immigrant youth from the opportunity structures of U.S. society. My analysis is, furthermore, grounded in the disproportionate likelihood that U.S. educated Latinos who do attend postsecondary institutions will enroll in two-year colleges where they are also very likely to be identified for basic writing coursework (Salas et al.).

With the visible emergence of a so-called "Generation I.5" (U.S. educated first-and second-generation children of immigration), advocacy for students such as María Jesús has become an area of concern within the larger umbrella of postsecondary composition studies and practice (Roberge, Siegal and Harklau). Sweet Water College's ESL basic writers hailed from many parts of the world and spoke a number of languages. However, U.S. educated Latinos comprised the majority of seats in Taylor's basic writing classrooms. Some had been born in Georgia or another U.S. state. Some had come with or followed their parents at a very young age. Some had come as middle or high school students. With few exceptions, they entered Sweet Water with a U.S. high school diploma. In the context of Sweet Water College-issues surrounding immigration were without a doubt Latino-centric and talk of "Generation I.5" more accurately about "Generación I.5." Yet, as my colleagues and I have speculated (Salas et al.), perhaps because of the Asian origins of the concept of Generation I.5, and also because of the rela- 
tively recent appearance of Latinos on two-year college campuses, Latinos identified for various remedial literacy coursework are often more broadly categorized as English Language Learners.

Contemporary discussions about second language learners in postsecondary coursework (or aspiring to postsecondary coursework) have included, among other things, the need for better informed placement assessment practices (Di Gennaro), alternative grammar instruction (Rustick), support services (Goldschmidt, Notzold and Ziemba Miller; Miele; Thonus); and, access to academic cultures and writing (Williams and Garcia; Zamel and Spack). In contrast, critically poised efforts rejecting the "linguistic innocence" (Lu) of better-practice-paradigms have worked to expose and dismantle the complex and layered histories of monolingual English developmental writing instruction (Horner and Trimbur), deficit representations of U.S. educated children of immigrants in postsecondary education (Harklau; Ortmeier-Hooper); ideologies of normalization (Cangarajah; Crisco; Gutierrez, Hunter Jevon and Arzubiaga; Portes, Delgado-Romero and Salas), and under-funded public education driven by state-mandated testing (Bernstein). Indeed, since Lu's landmark reproof of "linguistic innocence," the field has shifted from a relatively narrow focus on pedagogical concerns to engagement with "questions of literacy from rhetorical, philosophical, sociocultural, political, gender studies, and historical perspectives, sometimes all in the same study" (Durst 78). Or, as Canagarajah has argued, "Since everything that is taught already comes with values and ideologies that have implications for students' social and ethical lives, teaching is always problematic" (I6).

Here I recount how, in the setting of a two-year college in North Georgia in the spring of 2006, Taylor St. John's advocacy for the Latino immigrant students she served was complicated not only by existential questions of literacy but also by SB 529-a far-reaching legislative proposal that would have, among other things, denied all undocumented immigrants in Georgia access to public postsecondary education. In the sections that follow, I recount how Taylor's personal commitment to her students morphed into something exceedingly public in the form of a town hall meeting organized around the proposed legislation. My analysis of the meeting's aftermath suggests that, given the proliferation of legislative attempts to block immigrant Latino youth's access to the opportunity structures of postsecondary education, there is an urgent need for a disciplinary re-framing of the parameters of advocacy in basic writing. 


\section{COMING TO KNOW TAYLOR ST. JOHN}

My entry to Sweet Water College was the happy coincidence of my running into a graduate school classmate of mine shortly after the 2004 New Year. The coordinator of Sweet Water's ESL program, Meredith had been working at the College since Fall I997. I took advantage of our acquaintance to ask if she might know of an ESL classroom that I might observe. After a few phone calls, she had arranged for me to meet with Taylor, a Sweet Water ESL instructor who, Meredith explained, was "used to" having strangers in her classroom and sympathetic to graduate students in search of a field site. By mid-January 2004, I had made my first visit to the college, met with Taylor, and arranged for my participant observation of her ESL Advanced Grammar and Writing course. My travels to Sweet Water continued, and that initial forty hours of fieldwork grew into a dissertation study—five academic semesters of participant observation distributed over three years.

Although one motivation for doing my graduate study in Georgia had been the dynamic of its new Latino settlement and the research opportunities the phenomenon afforded, I had thought little of the public two-year college as a research site. Community colleges were, nonetheless, familiar childhood landmarks. In the mid-9o's, I too had taken a handful of courses at the Annandale Campus of Northern Virginia Community College, or "NOVA," to complete various undergraduate deficiencies for teacher certification. Ten years later, I found myself once again on the campus of a public two-year college-this time in Georgia. The ease with which I received approval from my own university's institutional review board for the Sweet Water pilot combined with the rapport I established with the participants during the pilot led me to commit to the site.

In its first iteration, the project was designed as an examination of English Learners' apprenticeship into academic writing. As the study and theoretical framework evolved, my focus shifted from teaching and learning the five-paragraph essay to understanding how teachers navigated an institutional environment where they were compelled to assume multiple, if not conflicting, roles and constituencies-advocates for the English learners they taught, and gatekeepers for the college that employed them. In sum, data generation totaled 250 hours of fieldwork, documented in $300+$ pages of field notes and $500+$ pages of instructional notes. The final semester of data collection was punctuated by a schedule of structured interviews and participant observation aimed at understanding how Taylor and her colleagues navigated the complexity of their institutional environment. It was 
during this semester and within this rich research context that the town hall meeting I describe here occurred.

\section{STUDENTS FOR A PROGRESSIVE SOCIETY}

A white Southern woman in her early 40 s and a self-described freethinker, Taylor lived in "the city" (Atlanta) with her equally freethinking Danish husband and two young children. She had been disturbed by the overall conservative/pro-Bush feeling of the campus-one that had grown more pronounced in the first years of the war in Iraq:

You know I felt that I was around a bunch of redneck right wing Republicans and I wanted to try to find some people that maybe felt a little bit more like I did and uh [laughing] I was just-I don't know-I was just a little bit surprised. Well, what surprised me was just the conversations I would overhear like a couple of years ago the buildup to the war in Iraq I would overhear faculty and staff laughing about it saying how we were going to go over and kick Sadaam's ass. And-you know-the Iraqis would drop their guns before we even set foot there. And just really, really ignorant kinds of rhetoric about A-merica A-merica A-merica's so great. And it frightened me. And I thought, "God there has to be some progressive thinking people up here."

For Taylor, the vast majority of student-centered organizations at Sweet Water were more focused on socializing than social issues. In fact, Taylor explained, she had been thinking of starting up something of a progressive club herself. By pure serendipity, somebody else had had the same idea, and in April 2005, an email appeared announcing the club. Taylor attended the first meeting and those thereafter. She was no longer alone.

When the club's official faculty sponsor needed to step down, Taylor accepted an invitation to replace her. In Fall 2005, Taylor and the Students for a Progressive Society (SPS) organized a Io-day fundraiser for Hurricane Katrina survivors that included a concert by a student punk rock band, "Horrible Idea," whose lead singer was the SPS President and veteran of the war in Iraq. On October I8, the club and the Colloquium Series Committee hosted a Nobel Peace Prize winner's talk about "The New Nuclear Danger"; on October 26, another invited lecturer described his view of how the U.S. had squandered the immediate compassion that the tragedy of 9/II had gener- 
Advocating for Latino Immigrants in a North Georgia Two-Year College

ated in the Muslim world. On Veteran's Day, SPS and its more conservative student-led counterpart, the Politically Incorrect Club, co-sponsored a panel discussion of veterans who had served in Afghanistan or Iraq. Taylor was proud to share the Students for a Progressive Society's vision and mission, “To be socially and politically active; to promote tolerance and critical thinking; to raise awareness of important social issues; to donate time and resources to worthy causes; and to make the world a better place in which to live." The club was, from Taylor's point of view, all about creating dialogue in an area of the country that needed it desperately-dialogue about the ongoing war in Iraq and about other issues such as Latino immigration.

\section{“HE'S UNDOCUMENTED; HE HAS TO PAY OUT OF STATE TUITION"}

In the 9o's, several hundreds of thousands of Latinos had settled in North Georgia communities (National Council of La Raza). The poultry plants and carpet mills for which the state was famous had especially benefited from the influx of cheap labor; and the region's billboards and storefronts announcing a mega flea-market or a gun dealership competed for the new settlers' attention. In North Georgia, however, the appearance of Spanish-language billboards on I-85 was complicated by the state's historical alignment with white supremacist ideology. Sweet Water College was a short Sunday drive from Stone Mountain, the site of the founding of the second Ku Klux Klan in I9I5 (MacLean). Local and regional newspapers documented increasingly common hate crimes aimed at Latino communities and individuals. Furthermore, with the 2006 elections on the horizon, Latino immigration had emerged as a pivotal issue for both sides of state and national aisles. Pro-labor CNN commentator, Lou Dobbs, spoke of working middle class outrage and of self-styled "cultural warriors" (O'Reilly) securing the southern border. In Fall 2005, legislation was proposed that would eventually become SB 529-Georgia Security/Immigration Compliance Act (Georgia General Assembly). As introduced, SB 529 was a far-reaching proposal that would have denied all undocumented immigrants in the state of Georgia access to public services including the state's colleges and universities.

Taylor and the Students for a Progressive Society followed the legislation as it passed from one chamber to the next and back to committee again. At a January 2006 progressive summit, the President of GALEO (Georgia Association of Latino Elected Officials) encouraged the organization of town hall meetings about SB 529. In mid-February, the club organized three 
screenings of "Wetback: The Undocumented Documentary." By the end of the month, the club announced its own town hall meeting on illegal immigration for Monday, March 6th, 7-9 p.m. with campus flyers promising "civil discourse on one of the most contentious topics facing our state and nation today: illegal immigration."

\section{“They Look Like My Students"}

In the weeks leading up to the town hall on illegal immigration, Taylor steadily grew more excited-busily planning the event between teaching classes and administrating the ESL program. However, Taylor's concern about the postsecondary opportunities of immigrants and immigrant children was something that she had expressed early on in data collection-a concern that begun even before I began visiting Sweet Water.

Notably, ESL Learning Support was potentially costly with in-state tuition and fees for the complete Io-course/34 credit ESL sequence totaling $\$ 2,600$ and nearly \$IO,ooo for non-residents. Taylor explained that in her second semester at the college, one of her students did not return- "one of our best students." A faculty colleague explained, "Oh he can't afford tuition because you know he's undocumented. He has to pay out of state tuition." What it meant to be an "illegal immigrant" was suddenly less abstract for Taylor. She explained her "awakening" in one of our interviews:

I started translating in my mind, "Oh, illegal immigrant-That's what that means." And then ... I said, "Oh, so this is what illegal immigrants look like. They look like my students." And that's when I became interested; but I was more interested at that time about how much tuition they had to pay. Then when all these laws all these bills started being presented last year that would impact them and keep them out of schools altogether then I felt that I had to speak out who else was going to they weren't going to speak for themselves cause they're scared. I think the "Shhhhhhhhhhhhh!-We've got undocumented students!" — and— "Let's not really talk about it"— and- "We don't really know who they are"-I don't think that's helping anybody.

The proposed legislations repulsed her as did the lack of an institutional stance on the issue. Organizing the town hall was, she felt, her duty, "You know I-I had no choice any teacher would do that for his or her students." 


\section{THE TOWN HALL MEETING}

By 7:Io p.m., all 300 seats in the Sweet Water College auditorium were taken. Breathless, Taylor stood at the door surveying the crowd. Parents had come with their small children, students with their friends, faculty with their colleagues, and members of the greater Sweet Water community. The afternoon had been particularly stressful. Only a few hours earlier, the Mexican American Legal Defense and Education Fund (MALDEF) legal counsel had called to say that she was double-booked and would try to make it-but would be late. The Latino Senator, a Democrat, had pulled out as well because of a double booking. The six-person panel had shrunk to four: a Methodist minister, the former mayor of Sweet Water, a local radio talk show host, and the State Senator from Woodstock, whose proposed legislation was, implicitly, the focus of the forum.

Speaking to the auditorium's full capacity, Taylor welcomed the crowd, saying, "We've come to have a respectful dialogue which defines us as an institution and a nation. We have a distinguished panel of experts who will inform us and an extraordinary moderator by whom our civil discourse will be facilitated [Applause]."

The moderator, a veteran Sweet Water professor of Spanish, took the microphone to explain that each panelist would have two-minutes for opening remarks after which she would address questions generated by the audience to the panel as a whole or to an individual panelist. These questions were to be written on the yellow index cards that the Students for a Progressive Society were busy distributing at that moment. Responses would be limited to three minutes per person per question.

Opening the forum, the talk show host, a white Southern woman, explained that her own grandmother had come to the U.S. in I9O3 and again in 1907-arriving at Ellis Island with only \$2.00 in her pocket. The difference, she explained, was that her grandmother, like millions of others, had obtained their citizenship legally. The white Republican author of the bill jokingly explained that had Taylor not been "so doggone persistent," he probably would not have come that evening. He clarified to the audience that he was not going to share his own opinion about how he thought things ought to be in a perfect world. Rather, his job was to uphold the law. Once in America, individuals legally here could change the law through political engagement. The round-robin continued with the former mayor, an AfricanAmerican woman, remarking on her inadequacy of being on a panel of such distinguished individuals and thanking the college for the invitation; and, 
finally, the reverend minister, a Latino, described the contested legislation as a convenient wedge issue for the 2006 elections.

As the moderator read the yellow cards to the panelists, the audience listened attentively - applauding politely at the end of every response. Had the town hall meeting ended then, it would never have made the news. The Senator made his points eloquently. The talk show host enjoyed herself. The minister raised some points. The former mayor pretty much kept quiet. Then it all changed.

\section{A Late Arrival}

More than an hour into the forum, the Southeast Regional counsel for MALDEF arrived. The moderator stopped the questions and invited the counsel to give her opening two-minutes remarks, reproduced here from a video transcript of the event:

The attendance here today is a perfect sentiment of that...SB 529 is something that is not new. We debated it 20 years ago; and, we defeated it in court. That was Proposition I87. It similarly sought to deny public benefits to undocumented residents-but of the state of California. My organization was an integral part in ensuring that that was found unconstitutional. But, unfortunately, because 20 years later we have people who are still resisting the contributionthe economic and the labor contribution-of our undocumented immigrants, we are seeing the same anti-immigrant legislation being introduced and to some certain small extent successfully in the state of Georgia. It's not what we want for the state of Georgia. And I urge you all to oppose it [Applause].

With the town hall suddenly falling into the MALDEF counsel's hands, the talk show host angrily accused the lawyer of fear mongering, of incendiary talk, and of calling people names!

Talk Show: - And for waltzing in a half hour late on an otherwise perfectly civil discussion. [Applause]

Lawyer: Oh, really? What name did I call you?

The moderator asked the talk show host to address the question rather than the other panelist- "Do us the honor of speaking to the audience rather than 
to the other panelist." The talk show host abruptly pulled herself out of her chair and stormed out of the packed auditorium. [Wild applause and catcalls]

This was North Georgia, after all, and when a (white) Southern woman-a locally celebrated one at that-walked out of a full house because she felt she was being disrespected, it was a big deal. The moderator, also a (white) Southern woman, remained, nevertheless, admirably composed:

Moderator: We would of course rather have you return.

Talk Show: [Walking up the padded aisle and then turning] Well, I mean really this was not what the lawyer wanted to achieve here! She came in with an agenda! She called people racist! And she called racial profiling-

Moderator: [Nodding her head and smiling] Thank you, nonetheless, for attending.

The former mayor, also a (black) Southern woman, stepped in to save the day. In a soft calming voice, she gently asked if she could "just plain old talk." The moderator nodded. Whispering, the mayor began:

I think arguing about illegals and [pause] all of this —it doesn't really accomplish much. What we need to be doing tonight is brainstorming about the solutions of what we'd like to see done [pause]. Somehow, we've got to work through-this is an issue. No matter who we are, it is an issue. So all of us please need to do constructive discussions tonight, please. Thank you. [Grateful applause]

The lawyer apologized for her late arrival, the Senator jumped back in and the debate continued between them. In the sequence of closing remarks, the lawyer spoke last; and, yes, she concluded, SB 529 was about race. This was the South; it was always about race. [Thank you, thank you. Applause and handshakes] The town hall was officially over.

\section{TROUBLE IN SWEET WATER}

A day after the event, SB 529 passed the Republican-controlled Senate chamber 40-I3. That debate also lasted two hours. On 23 March, the House passed it. On I4 April, the Governor signed SB 529 into law. As originally proposed, the Georgia Security/Immigration Compliance Act would have 
denied access to public services to all illegal immigrants in the state. It would have denied undocumented young men and women entry into the state university system. It would have required law enforcement officials to check the immigration status of anyone they arrested. In its final, heavily negotiated version, children would receive state health services regardless of their residency status; emergency care and treatment of communicable diseases would be available to everyone. All could attend college. Finally, only those individuals arrested on felony charges would be checked for their legal status (Georgia General Assembly, 2006).

Although the town hall did not prevent SB 529 from passing, many at the college thought, as did Taylor, that the meeting had been, overall, a great achievement. The moderator had been extremely level-headed. The questions from the audience had been thoughtful. The Students for a Progressive Society had learned an awful lot about how a bill became a law. Sweet Water had reached out into the community. Of course, it had been unfortunate and unintended that the talk show host had stormed out-but that had been the talk show host's prerogative. From Taylor's perspective, all these things were good.

\section{An "Often-Tense Debate"}

The city's newspaper ran an article about the "often-tense debate" on 7 March. On I2 March, a second story ran about the "immigration enigma"again citing the town hall at Sweet Water as an example of the emotional public debate in Georgia over illegal immigration. On I April, the same local newspaper reported that the forum had not gone over as well with some unnamed members of the state legislature. The town hall-reportedly-had nearly cost Sweet Water a $\$ 5$ million addition to its student center. The paper reported the rumor that funds, earmarked for the college, had almost been redirected to more deserving, i.e. conservative, units of the University System that did not treat guest panelists rudely.

The President of Sweet Water, unaware of the appropriations committee's concerns, was quoted as saying: "It's unfortunate that there would be any kind of sign that we should not explore ideas in a civil discourse on a college campus." A member of the faculty wrote a letter to the editor asking if anyone else in Sweet Water had mistaken the I April article for an April Fool's joke.

Livid, Taylor left for the weekend to attend the statewide annual Learning Support Conference. She would present a paper, "Educating the 
Undocumented." Friends that she trusted, such as the Director of Learning Support, had warned her over the weekend to be very careful:

I was talking about this pretty much non-stop for the first couple days of the convention because I was soooooooooo angry—she was like, "Taylor, okay you have to take a deep breath. You have to relax. You have to you" - you know she's a-she's a Southern woman and she's very diplomatic. And she's, "Okay, you know, you have to be very careful that it doesn't jeopardize your position.”

For the time being, Taylor explained that she was just trying to take a couple of days before she did anything more-before she sent, for example, her own editorial to the paper.

On I8 April, another article appeared in the same paper revealing that I7 illegal immigrants had received in-state tuition at Sweet Water State. In response, the President of the college issued a candid written statement explaining that, yes, I7 undocumented students had indeed received in-state waivers. On the other hand, the President argued, all seventeen were Georgia residents. All had graduated from the state's high schools. All showed great academic promise. Furthermore, no law had been broken. The waivers had been in accord with University System policies. The President reasoned that it would be better, after all, if those seventeen young adults stayed in school.

\section{The Death Threat}

Not long after the I8 April article appeared, a death threat was phoned into the Dean's office. No one was there to answer it. He left a message. The Dean had Taylor come to his office to hear it:

- And he was using the $\mathrm{f}$ word over and over again - and, you know, they considered it a serious threat. It was almost like a death threat:"All the faculty-everybody up there-needs to be shot. You're just fucking giving away these-this free education to these fucking illegals and I fuck, fuck," and on and on and on ... He called the dean's office, his secretary-yeah and-and he sounded like a Caucasian-maybe, thirty-something. He sounded a little bit thicktongued like he might be drinking or doing drugs, but he sounded outraged and scary—and people up here have guns, Spencer. 
The Dean and the others told Taylor to cool it. Were any of the media to call, she should refer them to the President's office. Taylor was scared.

In our final interview that semester, Taylor explained that although it had been her intention to shake things up, she had never wanted it to get to the point where people would be worried about their lives. Admittedly, Taylor had been somewhat naïve in thinking that her public activism on behalf of undocumented Latino residents would not possibly entail unpleasant consequences-including becoming visible, being made a target, and possibly attracting dangers upon allies such as her colleagues at Sweet Water and upon those very students and students' families for whom she was advocating. Just as Taylor had "translated" her students' situations to faculty in the past, she had trusted that people would be reasonable-that they would understand her students just as her colleague had eventually come around to Maria Jesus' request to borrow the un-subtitled videos earlier that semester. The town hall meeting had been an extension of her teacherly role-an intensely public explanation to the larger community of who her students were and the issues that concerned them and their families.

Taylor worried about the death threat. She worried about the elections and the wedge that immigration had created. She worried about a fence being built across the border. She worried that the Board of Regents would interpret SB 549 as meaning that the University System could no longer offer in-state tuition to non-residents-not anywhere. She worried how students were going to be able to pay out-of state-tuition. Taylor hoped that the town hall and its fallout had not affected her teaching. She explained, "I know that I was pulled in a lot of different directions this semester whereas in the past-before I took on the role of coordinator and also, um, faculty advisor for the progressive club-I really just focused on teaching." She had been distracted-maybe. No, she did not think that her teaching had suffered, although she could not really say either way. She hoped not. What was true was that it had been a tough semester. She had gotten personally involved. By the end of that semester, she had become less confident.

A summer later, in Fall 2006, Taylor still had her job. The Students for a Progressive Society were still programming events in preparation for the upcoming November elections. The college had not lost its \$5 million for a new student activity center. No one had come to Sweet Water to shoot the faculty. For another semester, a dozen undocumented students would keep their in-state tuition waivers while the University System waited for the Board of Regents to set a definitive policy. How SB 529 was to play out was still unclear. What was certain was that the town hall meeting and its 
aftermath created a momentary sense of instability in a public two-year college in North Georgia where nothing much ever happened and wasn't supposed to-beyond the day to day, semester to semester, year to year routine I had seen play out over five semesters.

\section{ADVOCACY AND PROFESSIONAL IDENTITY: A TENUOUS CLIMB}

Thinking about Taylor's seemingly assimilationist pedagogy cum grassroots political activism, I turn to Holland et al.'s notion of "improvisation" and "figured worlds." Bringing Vygotskian understandings of the liberatory and seemingly limitless possibilities of the semiotic mediation of children's play to Bakhtin's notion of the dialogic self, Holland et al. theorize a human propensity "to figure worlds, play at them, act them out, and then make them socially, culturally, and thus materially consequential" (280). Accordingly, Holland et al. propose the construct of "figured worlds" - worlds that women and men collectively write and rewrite in practice.

Sweet Water ESL Learning Support was one such figured world-a blueprint of what constituted a "fully" educated person and who has the right to be/become one. Taylor St. John was not completely comfortable with the five-paragraph essay as the be-all and end-all of Learning Support coursework. Yet, Taylor taught to the test that she did and didn't believe in because that was how she understood it had to be; and, because, after years of practice, she had become very good at doing so. That was her advocacy (see, Salas "Roberta"; Salas " Something That You're Proud of "); but that was not all of it. What the town hall meeting and its aftermath created for Taylor and her colleagues was the sense that their professional identities as ESL instructors were potentially variable and interactive. Taylor herself was capable of improvising her subject position-i.e., finding spaces to re-describe herself in the figured world to which she had been recruited as a participant. Illustrating their concept of "improvisation" with an anecdote from their study in a Nepalese village, Holland et al. tell the story of Maya-an "untouchable." Arriving for an interview, Maya's caste status prohibited her from entering the researchers' temporary home through the front door lest she "pollute" the cooking area. Intent on keeping the meeting, Maya climbed up the side of the house and into Holland and Skinner's office. Climbing up the side of a stone house in rural Nepal was Maya's non-scripted improvised alternative to the subject positions afforded to her at that moment_- "Led by hope, desperation, or even playfulness, but certainly by no rational plan" (6). 
In the figured world of ESL Basic Writing in North Georgia, Taylor and her colleagues, in large part, perceived their own agency through institutional measures of what it meant to be ready for college-level coursework and their success in preparing their students for such measures. The sorts of errors on a hand-written, timed five-paragraph essay that had categorized her students as "basic writers" would continue to categorize them as such were she not to teach her students what those errors were and how they might avoid them. For Taylor, teaching to the tests was an issue of access. It was the most obvious sort of agency available to her; and, she had become exceedingly good at doing so. In the spring of 2006, standing up against anti-Latino immigration was also about fighting for her students' access to the institution-this time physical. Granted, there were inconsistencies in Taylor St. John's professional subjectivities. She did not challenge the curriculum. However, Taylor did challenge proposed legislation that would have quite literally exclude undocumented students from attending Sweet Water or, for that matter, any tertiary institution in the state. The town hall meeting had been Taylor's public climb up the side of a house. In its aftermath, she mobilized a college.

Taylor's politicalization of her professional identity was an improvisation mediated by the contexts and circumstances of teaching Generación I. 5 basic writers in North Georgia. Durst described the most common depiction of the college composition instructor in published work spanning the previous I5 years as “A critical teacher, shaping students' literacy, intellectual and cultural development through pedagogies of social justice and political analysis" (92). Taylor was not the sort of teacher Durst described-at least not in the way she trained the young women and men who entered her classroom to navigate the labyrinth of assessments that would determine their academic trajectories. Taylor never overtly challenged her institution's conceptualization of what it meant to be ready for college-despite a vast body of literature for the profession exposing the exclusivity of such paradigms and their potentially noxious effects on students from outside the heterosexual, white, North American, middle class. That said, whatever sort of teacher Taylor was or was not, her professional identity was shaped in Spring 2006 by the highly political nature of teaching transnational children of immigrants-a politic intensified by fears of limited resources, reverse discrimination, and an unstable national identity (Sanchez). In its most radical versions, new American nativists have framed post-I965 immigration as preternatural Aryan retribution for the destruction of Nazi Germany (Brimelow 254). In the face of such rhetoric, I suspect that basic writing faculty such as Taylor 
Advocating for Latino Immigrants in a North Georgia Two-Year College

do a lot of interpreting on behalf of their students-helping colleagues understand their challenges and their potential. I have told Taylor's story for a number of reasons not the least of which was that Taylor herself asked me to tell it so that people would know what had happened-or what had almost happened-in a two-year college in North Georgia that semester. It has taken me several years to process the events of the town hall meeting and to articulate my understandings of Taylor St. John, her complexity and contradictions, and the inconsistent but intensely literal way in which she re-framed her own advocacy that spring. In the early I980's, Lu wrote of "linguistic innocence"-exposing the essentialist underpinnings of pedagogies that framed language as a politically innocent vehicle of meaning. However, as I finish this manuscript-some six years after the town hall meeting and more than II years after Orrin Hatch (R-UT) and Richard Durbin (D-IL) first proposed DREAM Act legislation to the U.S. Senate-I am unable to find via an EBSCO Discovery search a single manuscript in the Journal of Basic Writing, Teaching English at the Two-year College, or College Composition and Communication that has ever made mention of the term. A similar search for "Dream Act" resulted in one instance in the Journal of Second Language Writing (see, Fránquiz and Salinas) and zero hits in TESOL Quarterly. This too reveals a sort of innocence. Granted, there were inconsistencies in Taylor St. John's professional subjectivities. But what is also troubling is that strands of activist basic writing scholarship continue to not conceptualize and not write about contemporary legislative attempts to block Latino immigrants' physical access to public higher education.

In the shadow of Stone Mountain, Taylor St. John led a charge up the side of the figured world of Sweet Water College. Perhaps in the aftermath of a town hall meeting, a discipline historically committed to being socially, culturally, and, thus, materially consequential might also recognize and move up the side of its own disciplinary insularity to engage more explicitly with contemporary political issues surrounding Generación I.5's physical access to the opportunity portal of basic writing.

\section{Notes}

I. Taylor St. John, Sweet Water College, Hogg Mountain, and other such identifiers are pseudonyms. Any real world counterparts are purely coincidental. 


\section{Works Cited}

Bernstein, Susan Naomi. "Teaching and Learning in Texas: Accountability Testing, Language, Race, and Place." Journal of Basic Writing 23.I (2004): 4-24. Print.

Brimelow, Peter. Alien Nation: Common Sense About America's Immigration Disaster. Ist ed. New York: Random House, I995. Print.

Canagarajah, A. Suresh. Resisting Linguistic Imperialism in English Teaching. Oxford University Press, I999. Print.

Crisco, Virginia. "Rethinking Language and Culture on the Institutional Borderland." Journal of Basic Writing 23.I (2004): 39-63. Print.

Di Gennaro, Kristen. "Assessment of Generation I.5 Learners for Placement into College Writing Courses." Journal of Basic Writing 2I.I (2008): 6I79. Print.

Durst, Russel K. "Writing at the Postsecondary Level." Research on Composition: Multiple Perspectives on Two Decades of Change. Ed. Peter Smagorinsky. New York: Teachers College Press and the National Conference on Research in Language and Literacy, 2006. 78-IO7. Print.

Fránquiz, Maria, and Cinthia S. Salinas. "Newcomers Developing English Literacy through Historical Thinking and Digitalized Primary Sources."Journal of Second Language Writing 20 (20II): I96-2Io. Print.

Georgia General Assembly Legislation (2006). As introduced o6 LC I8 5198 SB 529 - Georgia Security/Immigration Compliance Act. Web. I3 Dec. 2006.

Goldschmidt, Myra M., Norman Notzold, and Cristine Ziemba Miller. "ESL Student Transition to College: The Thirty-Hour Program." Journal of Developmental Education 27.2 (2003): I2-I7. Print.

Gutierrez, Kris, Hunter Jevon, and Angela Arzubiaga. "Re-Mediating the University: Learning Though Sociocritical Literacies." Pedagogies: An International Journal 4.I (2009): I-23. Print.

Harklau, Linda. "From the 'Good Kids' to the 'Worst': Representations of English Language Learners across Educational Settings.” TESOL Quarterly 34.I (2000): 35-67. Print.

Holland, Dorothy C., William Lachicotte Jr., Debra Skinner, and Carole Cain. Identity and Agency in Cultural Worlds. Cambridge, MA: Harvard University Press, I998. Print.

Horner, Bruce, and John Trimbur. "English Only and U.S. College Composition." College Composition and Communication 53.4 (2002): 594-630. Print.

Lu, Min-Zhan. "Redefining the Legacy of Mina Shaughnessy: A Critique of 
Advocating for Latino Immigrants in a North Georgia Two-Year College

the Politics of Linguistic Innocence." Journal of Basic Writing Io.I (I99I): 26-40. Print.

MacLean, Nancy. Behind the Mask of Chivalry: The Making of the Second Ku Klux Klan. New York: Oxford University Press, I995. Print.

Miele, Carol. "Bergen Community College Meets Generation I.5." Community College Journal of Research and Practice 27.7 (2003): 603-6I2. Print.

National Council of La Raza. Latinos in Georgia: A Closer Look. Washington, DC: Author, 2005. Print.

O'Reilly, Bill. Cultural Warrior. New York: Broadway, 2006. Print.

Ortmeier-Hooper, Christina. "English May Be My Second Language, but I'm Not 'ESL.'” College Composition and Communication 59.3 (2008): 390-4I9. Print.

Portes, Pedro R., Edward Delgado-Romero, and Spencer Salas. “Latinos (Not) in Higher Education and the Continuum of Group Based Inequality: A Cultural Historical Perspective." A Handbook of Diversity in Higher Education. Eds. D. Sandhu, B. Hudson, and M. Taylor-Archer. New York: Nova Science Publishers, in press. Print.

---. “'Turn in Something That You're Proud Of'-Pedagogical Scripts and the Re-Education of U.S. Educated English Learners." Power, Privilege and Education: Pedagogy, Curriculum and Student Outcomes. Ed. Greg Wiggan. New York: Nova Science Publishers, 20II. I33-47. Print.

Roberge, Mark, Meryl Siegal, and Linda Harklau, eds. Generation I.5 in College Composition: Teaching Academic Writing to U.S.-Educated Learners of Esl. Vol. Routledge. New York, 2009.

Rustick, Margaret Tomlinson. "Grammar Games in the Age of Anti-Remediation." Journal of Basic Writing 26.I (2007): 43-62. Print.

Salas, Spencer. "Roberta; or, the Ambiguities: Tough Love and High Stakes Assessment in a Two-Year College ESI Learning Support Program in North Georgia." Journal of Basic Writing 27.2 (2009): 5-28. Print.

---. "Teaching and the Dilemma of the Personal: Lodoiska's Story." TESOL Journal I.3 (2010): 368-78. Print.

Salas, Spencer, Pedro R. Portes, Mark M. D’Amico, and Cecilia Rios-Aguilar. "Generación I.5: A Cultural Historical Agenda for Research at the TwoYear College." Community College Review 39.2 (2OII): I2I-35. Print.

Sanchez, George J. "Face the Nation: Race, Immigration, and the Rise of Nativism in Late Twentieth Century America." International Migration Review 3I.4 (I997): I009-I030. Print.

Segal, Judy, Anthony Paré, Doug Brent, and Douglas Vipond. "The Researcher as Missionary: Problems with Rhetoric and Reform in the Disciplines." 
Spencer Salas

College Composition and Communication 50.I (1998): 7I-90. Print.

Thonus, Terese. "Serving Generation I.5 Learners in the University Writing Center.” TESOL Journal I2.I (2003): 17-24. Print.

Van Maanen, John. Tales of the Field: On Writing Ethnography. Chicago Guides to Writing, Editing, and Publishing. Chicago: University of Chicago Press, 1988. Print.

Williams, Mark T., and Gladys Garcia. "Crossing Academic Cultures: A Rubric for Students and Teachers." Journal of Basic Writing 24.I (2005): 93-II9. Print.

Zamel, Vivian, and Ruth Spack. Crossing the Curriculum: Multilingual Learners in College Classrooms. Mahwah, NJ: L. Erlbaum Associates, 2004. Print. 


\title{
Comedy Stages, Poets Projects,
}

\section{Sports Columns, and Kinesiology} 34I: Illuminating the Importance of Basic Writers' Self-Sponsored

\section{Literacies}

\section{Kevin Roozen}

\begin{abstract}
Dominant perspectives of basic writers' self-sponsored literacies tend to overlook the important roles such activities can play in literate development. Drawn from texts, interviews, and participant-observations collected during a five-year study, this article continues the examination of the relationship between one writer's curricular and extracurricular engagements begun in "Journalism, Poetry, Stand-Up Comedy, and Academic Literacy: Mapping the Interplay of Curricular and Extracurricular Literate Activities, "which appeared in JBW 27.I. This article examines the writing-related knowledge the writer gained from extracurricular engagements with stand-up comedy, poetry, and sports journalism and argues that he draws upon this knowledge to enhance his performance in a writing-intensive upper-division kinesiology class. Based on my analysis of these "laminated" literacies, I argue for a perspective of basic writers' self-sponsored literate activities that acknowledges the positive contributions they can make to learners' academic engagements and to their literate lives more broadly.
\end{abstract}

KEYWORDS: self-sponsored literacies; academic writing; lamination; literate development; intertextuality

In "The Contributions of North American Longitudinal Studies of Writing in Higher Education to Our Understanding of Writing Development," Paul Rogers lists a wealth of factors that inform students' growth as writers throughout their college years, including their cultural backgrounds, mentoring from professors, opportunities to write, teacher supportiveness, feedback from teachers and peers, and their lives outside of school (375). As a field, basic writing has paid close and careful attention to the impact of various factors on students' uptake of academic literacy. These factors

Kevin Roozen is Associate Professor of Rhetoric and Composition at Auburn University, where he teaches first-year composition and undergraduate and graduate courses in rhetorical theory, literacy studies, and literate development throughout the lifespan. His work has appeared in the Journal of Basic Writing, Kairos, College Composition and Communication, Research in the Teaching of English, Written Communication, and other journals and edited collections. With Gwen Gorzelsky, he serves as the co-chair of the Qualitative Research Network. 
include their cultural backgrounds (Lu, "From Silence to Words"; Gilyard; Smitherman), chances to write in and across a variety of genres and audiences (Adler-Kassner; Arca; Gabor; Pine), supportive instructors and instruction (Hull and Rose; Rose, Lives on the Boundary; Shaughnessy, "Diving In," Errors and Expectations), and employment and family obligations outside of the university (Sternglass). Rogers's list also includes students' pre-existing writing abilities (375), but this factor has received significantly less attention in the basic writing literature. While a handful of studies do offer glimpses of basic writers' literate lives outside of school (Courage; Hull, Rose, Frazer, and Castellano; Mutnick; Sternglass), that body of work has tended to understand self-sponsored (Gere 8o) and school-sponsored literacies as separate streams of literate activity. By not fully attending to basic writers' self-sponsored literacies and their potential contributions to the students' academic writing, we reduce the scope of their literate lives and identities as literate persons to only what we see in their work for college courses. As a result, our judgments about their literate abilities come to be based solely on their academic performances. By overlooking self-sponsored literacies, we also subtly but powerfully signal that such writing is not "real writing" and that such reading is not "real reading."

My initial contribution to the examination of basic writers' experiences with writing outside of school, published in the spring 2008 issue of $J B W$, drew from a longitudinal case study of Charles Scott, Jr., an African-American basic writer enrolled at the University of Illinois at Urbana-Champaign. In an effort to situate Charles's writing for his university courses within the larger literate landscape he inhabited, that study examined his school- and selfsponsored literate activities and also reached back to his literate engagements prior to attending the university. Using sample texts, interview excerpts, and notes from participant observation of Charles's writing activities, the analysis I offered in "Journalism, Poetry, Stand-Up Comedy, and Academic Literacy: Mapping the Interplay of Curricular and Extracurricular Literate Activities" illuminated not only his extensive participation with stand-up comedy, poetry, and extracurricular journalism, but also the creative and purposeful ways he drew upon those engagements to enhance his performance in two introductory courses he took during his first semester of college: Rhetoric IOI and Speech Communication IOI. To accomplish the analytical writing tasks for Rhetoric IOI (a credit-bearing basic writing course), Charles drew upon practices developed from his earlier experiences with researching and writing news stories for New Expression, a news magazine run by Chicago area teens. Likewise, to succeed in Speech IoI, Charles redeployed practices 
he had developed while performing stand-up comedy routines and giving public readings of his poetry. The dense "nexus of practice" (Scollon I6) linking school and non-school activities that emerged from that analysis prompted me to argue that "understanding Charles's development as an academic speaker or writer means taking into account his experiences with non-school journalism, poetry, and stand-up comedy as well as Rhetoric IOI and Speech IOI and how such engagements motivate, facilitate, and invigorate one another" (27).

In this article, I extend the analysis of the relationship between Charles's school- and self-sponsored literacies in three key directions. First, rather than focusing on Charles's experiences in introductory courses, this analysis attends to his performance in a writing-intensive upper-division class in kinesiology. Second, whereas my previous analysis emphasized Charles's writing and speaking, the present one also addresses his abilities to engage with texts as a reader. Third, rather than examining the ways that his multiple literate engagements are linked via the repurposing of practice, the analysis offered here explores how Charles redeploys the discourses animating his sports journalism, comedy routines, and poetry into the critiques he's asked to produce for the kinesiology class. I argue that Charles's success in Kinesiology 34I is due in large part to the crucial connections he forged between the reading and writing for that course and his far-flung network of self-sponsored literate engagements, including his stand-up comedy routines, poetry, and sports journalism stories. Further, I use Charles's successes in drawing upon these self-sponsored literacies to argue for a more nuanced and productive perspective of basic writers' selfsponsored writing. In addition to providing a look at a so-called basic writer navigating the literate demands of an upper-division undergraduate course, this article contributes to basic writing scholarship in a number of ways. By devoting sustained attention to one student's multiple non-school writings, particularly genres such as stand-up comedy and journalism that have not been addressed by previous scholarship, this article extends accounts of basic writers' self-sponsored literacies. In addition, it theorizes and empirically maps the dialogic connections between academic and self-sponsored literacies rather than viewing them as discrete activities. In doing so, it contributes to the development of theoretical and methodological approaches that not only make visible the expansive intertextual and interdiscursive pathways connecting students' multiple literate engagements, but it also views the development of academic writing and reading abilities in relation to, rather than as separate from, other literacies. 


\section{LEARNING TO VALUE BASIC WRITERS' MULTIPLE LITERACIES}

As Bruce Horner notes in "Relocating Basic Writing," BW scholarship has long recognized the wealth of "additional" resources and experiences that basic writers bring to the university from their families and communities (56). By far, the majority of that research has focused on the rich diversity of languages and language varieties, particularly national languages and varieties of English, that basic writers have at their disposal (Canagarajah; Gilyard; Horner, Lu, Royster, and Trimbur; Lu, "From Silence to Words"; McCrary; Lu and Horner, "Translingual Literacy"; Smitherman). Informed by such a perspective, the field has come to recognize that even those basic writers who speak only English "are nonetheless multilingual in the varieties of English they use and in their ability to adapt English to their needs and desires" (Horner, Lu, Royster, and Trimbur 3II). In addition to helping us recognize the rich variety of languages and language varieties our students possess, that scholarship has also helped us to view linguistic diversity as a resource upon which basic writers can and do draw, rather than as a hurdle they need to overcome, as they navigate the demands of their coursework. In short, our understanding of basic writers' multiple languages and language varieties as resources for meeting academic demands is informed by what Horner describes as a "traffic model of linguistic heterogeneity" ("Relocating Basic Writing" 59). In such a model, persons are continually meshing together the multiple linguistic resources they carry from their multiple engagements. The discourse at play for any given activity is informed by the linguistic forms found at that location as well as those brought from other locales. In other words, persons do not set one language variety aside for another as they move from setting to setting, but rather they continually blend their various language varieties together as they move across contexts.

In contrast to the wealth of scholarship that has examined basic writers' linguistic resources, research on their multifaceted engagements with literacy as a resource for their academic pursuits has been slower to emerge. What we know of basic writers' self-sponsored literacies arises from a handful of studies that have glimpsed students' literate lives beyond the classroom. In "The Interaction of Public and Private Literacies," Richard Courage briefly describes the letters, notes, forms, and shopping lists written by Ethel, an adult community college student enrolled in a basic writing class. In "Remediation as a Social Construct: Perspectives from an Analysis of Classroom Discourse," Glynda Hull, Mike Rose, Kay Fraser, and Marisa Castellano mention the short stories and the romance novel written by Maria, a basic 
writer in an undergraduate composition class. In Writing in an Alien World, Deborah Mutnick offers a more detailed portrait of two science fiction novels written by Joe Baxter, a basic writer participating in her research. Although not focused exclusively on basic writers, Marilyn Sternglass's Time to Know Them describes the poetry, short stories, and novels written by Jacob, one of the participants in her longitudinal study of CUNY (City University of New York) students.

Not only has scholarship addressing basic writers' additional literacies been slower to emerge, but the relationship between those literate activities and students' academic writing remains grounded in what Horner describes as an "archipelago model" (57). Like the "traffic" model, the "archipelago" model acknowledges and accounts for the rich variety of resources persons have in their repertoires; however, rather than depicting those resources as being carried from one site to another and blended together, the archipelago model assigns each resource to an appropriate sphere of use and depicts those spheres as discrete, autonomous islands. Rather than meshing together language practices from different spheres, persons are depicted as trading in one set of practices for another as they move out of one locale and into another. In keeping with this archipelago model, studies of basic writers have recognized the kinds of writing they do outside of school, but at the same time they have tended to overlook the possibility that such literacies might flow into and influence students' academic writing. Describing the relationship between Ethel's engagements with out-of-school writing - for example, letters, notes, shopping lists, and so on-and the writing she encounters in her classes, Courage comments that her "private literacy had few points of congruence with the public literacy of the schools" (488). Likewise, Hull, Rose, Fraser, and Castellano observe that Maria's teacher applauds her for having written a novel, but at the same time they note that "she devalues Maria's extra-institutional literacy activity and negates the possibility that she could learn things about literacy from it" (3I5). The teachers in Mutnick's study admire Joe Baxter's investment in his novels, and his talent prompts them to wonder why he was placed in basic writing, but they still regard his self-sponsored writing as separate from the essays he writes for his BW class. In much the same manner, Sternglass repeatedly celebrates Jacob's passionate commitment to his poetry, short stories, and novels and states how privileged she felt to talk with him about his creative writing, and yet her account depicts Jacob's self-sponsored literacies as running along a parallel path with his academic literacies, as discrete, autonomous writing activities. 


\section{WRITING AND READING AS LAMINATED LITERATE ACTIVITY}

In my earlier analysis of the relationship between Charles's school and non-school writing, I employed a theoretical framework informed by Vygotskian activity theory and Mediated Discourse Theory. This framework understood social action as being mediated by what Ron Scollon refers to as a "nexus of practice" (I6), a network woven from some practices that are local and unique to a particular social setting and others that have been spun-off from other sites of engagement. Understood from this perspective, social action is both situated in a particular setting and across a far-flung network of practice that stretches into other activities. This perspective highlighted the textual practices linking Charles's activities for two introductory courses with his stand-up comedy, poetry, and extracurricular journalism. To accomplish the analytical writing tasks for his Rhetoric Ior class, Charles drew upon practices developed from his earlier experiences with researching and writing news stories. Likewise, to succeed at the speeches required for his Speech ror course, Charles redeployed practices developed while performing stand-up comedy routines and giving readings of his poetry.

That analysis of the connections between Charles's school and nonschool writings suggested that his multiple literate engagements might be linked in ways that a focus on nexus of practice could obscure. In "Chronotopic Lamination: Tracing the Contours of Literate Activity," Paul Prior and Jody Shipka forward the notion of "chronotopic lamination" as a means of accounting for not only networks of practices but also "the dispersed, fluid chains of places, times, people, and artifacts that come to be tied together in trajectories of literate action along with the ways multiple activity footings are held and managed" (I8I). Their notion of "chronotopic lamination" is drawn from Mikhail Bakhtin's notion of the "chronotopic" nature of language-that language is embodied in actual concrete times, places, and events of life and in representations of those actual times, places, and events on paper, in talk, and in the mind-and Erving Goffman's notion of lamination-that multiple activities co-exist, are immanent, in any situation. Weaving these two constructs together, Prior and Shipka offer "chronotopic lamination" as a way to address "the multiplicity of embodiedand-representational chronotopes that are encompassed in any literate act" (I83). As an example, Prior and Shipka trace the network of literate activities that animate the act of reading a newspaper. Such an act, they write, 
is both localized in the concrete acts, thoughts, and feelings of the reader(s) and sociohistorically dispersed across a far-flung chronotopic network-including the embodied acts of writing the story, almost certainly spread across multiple chronotopic episodes of individual and collaborative composing; the histories of journalism and the genre of the news story; the actual embodied worlds being represented and their textualized representations; the reader's histories of reading papers and of earlier events relevant to those represented in the story; and so on. (I86-87)

When viewed as chronotopically laminated, the seemingly discrete act of reading a news story is part of an extensive network of literate activities that includes the history of the particular story, news stories as a genre, and journalism as a literate activity; the concrete times and places being addressed in the story and previous representations of those times and places; and the writer and readers' histories of engagement with newspapers and other texts. In other words, a full and rich accounting of what reading and writing entail demands that researchers understand literate acts as concrete and local even as they are dispersed across, and thus laminated with, other literate engagements.

According to Prior and Shipka, the laminated quality of literate activity arises from the fact that multiple activities are "co-developing," that elements from one domain are "always developing in association with other activities, actions, and artifacts" (207) no matter how different or disconnected those activities might seem. In other words, if literate acts are not autonomous islands but rather complexly connected to other acts associated with other social worlds, then understanding literate development demands that we consider the ways that any focal activity is developing in conjunction with, rather than apart from, other activities.

\section{CHARLES'S EXPERIENCES IN KINESIOLOGY 34I: A STUDY OF LAMINATED LITERACY}

Approaching Charles's writing for his later papers in Kinesiology 34I as part of a chronotopic network of texts, artifacts, persons, places, and times stretching into other engagements prompted me to look beyond elements of Charles's kinesiology class that might account for his ultimate success in that course. Below, I offer a closer look at Charles's first and second essays for this class. I then partially trace the network of Charles's literate engagements, 
including his stand-up comedy, poetry, and sports journalism, that appear to be informing his second essay and subsequent ones as well.

In her 1996 book, Deborah Mutnick uses the phrase "writing in an alien world" to describe basic writers' reactions to finding themselves in a world "dominated by the strange language of academic discourse" (IOO). This is an apt description for what Charles Scott, Jr., felt as a basic writer enrolled in Kinesiology 34I: Games in Culture, a writing-intensive, upper-division course he took during his freshman year at the university. Although he had not yet completed any of the prerequisites, or even the second of the two-course freshman rhetoric sequence required for entering students with the lowest scores on the university's placement exam, Charles had been granted permission to take the course, which explored game phenomena as cultural action systems. ${ }^{2}$ During one of our interviews that semester, Charles mentioned that he was shocked to discover that the majority of students enrolled were upper-level undergraduates and graduate students. Recalling his initial reaction to this course, Charles said, "I was really intimidated when I found out that I was the only freshman, and everyone else had taken a lot of kinesiology classes."

\section{The First Essay}

When Charles encountered the first of the course's five major writing tasks, each requiring a lengthy critique of a book that addressed professional and amateur sports and their relationship to larger social and cultural contexts, his initial anxiety increased. Scholarship on basic writers has elaborated students' struggles with the literate demands of introductory composition courses, which often require learners to read article-length pieces and write relatively brief essays or sometimes even shorter paragraph-length pieces. The lengthy and dense texts at the center of Kinesiology 34I, designed to challenge the literate abilities of juniors, seniors, and graduate students, would certainly require Charles to stretch, as both a reader and writer, in ways not usually assumed easy for basic writers.

Charles's struggle with the kinds of texts he was asked to read and write was apparent in the first essay he wrote for the class. Rather than offering a critique of the core arguments of the assigned book, Bernard Suits's The Grasshopper: Games, Life, and Utopia, Charles's first paper consisted mainly of a chapter-by-chapter summary of the book's content. In the two instances where Charles moved beyond summary, he did so merely by stating that he agreed with Suits's assertions and then provided a brief example from 
his own experience with sports as support. I offer here an excerpt of one of those instances, taken from Charles's discussion of Suits's third chapter: ${ }^{3}$

Suits believes that the rules of the game has a direct effect on the quality of the game. I agree with Suits. The rules of a particular game can break or make a game. Suits says if rules are defined too "loosely" the game would be boring because winning would be too easy. Suits says the less rules a game has, the more it falls apart. He also believes that without rules, we wouldn't be able to play the games we play. Example of a game without rules is a football video game called NFL Blitz. If the real NFL were without rules, there would be no more football. Because all the players would be dead because they killed each other.

In an effort to move beyond just summarizing Suits's point about the important role and function of rules, Charles states that he agrees with the author. A few sentences later, he offers the NFL Blitz video game as an example of a game with few rules, and makes the point that adopting this approach in the "real NFL" would cause the league to fall apart because the rules designed to protect the players would not exist.

In responding to Charles's essay, on which he received a grade of $\mathrm{C}$-, the professor focused the vast majority of her in-text and marginal comments on issues of verb tense, missing words, sentence clarity, and paragraph structure. Her other comments were aimed at encouraging Charles to read Suits's text more carefully, pointing to specific pages for him to re-read. In her brief end comment, the professor wrote, "[y]ou covered all the main points," but then echoed her earlier comments about the mechanical aspects of Charles's writing by stating, "[b]e very cautious of errors in sentence structure."

\section{The Second Essay}

Although Charles struggled with the initial paper for Kinesiology 34I, his response to the second assignment marked a clear turning point in his performance in the course. In this paper, students were asked to critique Charles Springwood's Cooperstown to Dyersville: A Geography of Baseball Nostalgia, an ethnographic study of professional baseball. Compared with Charles's first essay, his second one read much more like a critique than a summary, especially in terms of the ways in which Charles extended, complicated, and even challenged some of Springwood's key points with his own insights. 
In one of the essay's paragraphs, for example, Charles works to refine Springwood's point about "ballpark nostalgia." Charles opens this paragraph with a quotation from Springwood about the sense of loss baseball fans felt as their beloved stadiums moved out of urban neighborhoods. He then references Springwood's example of the Chicago Cubs' Wrigley Field as one of the few parks in close proximity to the city. Having established Springwood's point regarding fans' nostalgia for ballparks as the focal topic of discussion, Charles then offers examples from his own home team by mentioning White Sox fans' displeasure with "New" Comiskey Park, pointing particularly to its industrial look and enormous upper deck:

The White Sox have had this problem because fans don't like the New Comiskey Park because the stadium lacks character plus the upper deck. Families grow up with certain stadiums, and when the time comes to replace their stadium, they have a hard time letting go. Fans like the classic stadiums because those are the stadiums they identify with. It takes lots of time to identify with new stadiums.

Whereas Springwood identified the loss of connection to city neighborhoods as the source of baseball fans' nostalgia, Charles locates it in the loss of the classic styling associated with the stadiums that fans grew up with. Charles's point is not as developed as it could be, but I read his decision to introduce the example of Comiskey Park as a way to refine Springwood's point about the source of "ballpark nostalgia." By using Comiskey Park in this manner, Charles is able to move away from merely summarizing Springwood's point as he approximates the critique that his professor is expecting.

In the next paragraph, Charles turns his attention to a section of Springwood's book that discusses professional baseball's racial problems. Rather than employing his insights about the White Sox to subtly refine Springwood's point, as he had done in the previous paragraph, this time Charles draws upon the Sox to productively contest Springwood's position. Charles opens the paragraph by presenting readers with what he saw as Springwood's central assertion that baseball's Hall of Fame functioned to isolate racial inequalities in the sport's past and thus erase racial issues in the present. In the next sentence, however, Charles directly contests Springwood's position by proclaiming that "the refusal to hire minority coaches and general managers" is "a major problem [that] exists in baseball today." In doing so, Charles positions racial inequalities as a crucial issue in need of urgent attention rather than one that has been adequately addressed and 
thus comfortably relegated to the sport's history. As evidence to support his assertion, Charles points to the scant few African-American managers in contemporary baseball, adding that all three have winning records as a way to underscore that race, rather than coaching ability, is the central reason for the low number of Black managers:

Currently there are only three African-American managers in baseball, ironically all three have winning career records. And the best two teams in each respected league had a Black manager last season. Two of the three Black managers manage in Chicago. The Cubs and White Sox both have African-American managers. This season the White Sox also hired an African-American General Manager, making the White Sox the only organization in sports history to have a minority General Manager and Coach.

Closing the paragraph, Charles writes, "Yes, baseball is making progress towards equality, but problems still exist, which can only be corrected with time." In this final sentence, Charles makes clear his position with respect to Springwood's: while agreeing that baseball shows signs of moving beyond its racial problems, he also insists that such problems still exist and need to be addressed as the sport moves forward.

The professor's comments on Charles's second paper, as for his initial essay, are directed toward sentence-level and mechanical issues. However, this time, the professor also offers a number of positive comments. In her marginal comments, for example, she praises Charles for addressing a number of Springwood's key points. She also repeatedly applauds Charles's effective use of examples, writing "excellent example" and "great use of examples" in the margins of his paper and indicating multiple instances where she thought Springwood would agree with Charles's assertions. In addition, rather than focusing solely on Charles's problems with the more mechanical aspects of his prose, the professor also encourages Charles to address even more directly the cultural theory they are studying in class in order to provide a more focused critique and a tighter argument.

Charles's second critique for Kinesiology 34I is of interest for a number of reasons. First, as a reader, I was struck by the depth of Charles's engagement with Springwood's book compared with his response to the book for his initial assignment. In addition, this essay marked the first time that Charles's efforts at critique were seen as somewhat successful by the professor. Of greater interest, though, is how that success might be due in large 
part to Charles drawing upon discourses of professional baseball, and the Chicago White Sox and Comiskey Park in particular, and racial tensions in professional sports, both of which are topics he frequently addressed in his various self-sponsored literate activities. In the sections that follow, I examine an expanding intertextual and interdiscursive network linking Charles's second essay for the kinesiology course to three of his self-sponsored literate engagements: stand-up comedy routines that he performed while enrolled in the kinesiology class, poetry that he wrote some eight months before taking this course, and sports journalism stories he wrote almost a year earlier.

\section{Stand-Up Comedy}

Charles's repertoire of self-sponsored literacies included the stand-up comedy routines he performed once a month throughout his first year and a half at the university's monthly Open Mic Night and other universitysponsored venues. Charles began to perform these stand-up routines primarily as a way to get some experience speaking in front of an audience in order to bolster his poor grades in Speech Communication IoI, which he took during his first semester. His comedy routine included a rich blend of impersonations, one-liners, humorous experiences, and his own observations about life's twists and turns (see Roozen, "Journalism, Poetry, StandUp Comedy" for a fuller description of the origins of Charles's stand-up comedy routine, as well as the origins of his poetry and journalism that I mention in the next two sections). Once a month, Charles took the stage with fifteen or so new pages of material he had written in his red, spiralbound "joke notebook." He looked for material as he watched his favorite shows like ESPN SportsCenter, Saturday Night Live, and The Daily Show, read a number of newspapers, browsed the joke pages of magazines like Playboy and Maxim, collected visual texts posted around his residence hall, scanned through humorous e-mails his older sisters had sent him, and reflected on his own experiences.

Describing the key premise underlying stand-up comedy, Betsy Borns writes that "in order to make humor, it's necessary to point out 'what's wrong with this picture"" (52), something Charles was able to achieve through his focus on the provocative topics of sports and race. With their less than stellar ratio of wins to losses and declining attendance at home games, the White Sox were the focal point for much of his comedy. The Sox's home stadium, Comiskey Park, was also a frequent target of Charles's jokes, particularly its need for renovation even though it had been largely rebuilt in the early I990s. 


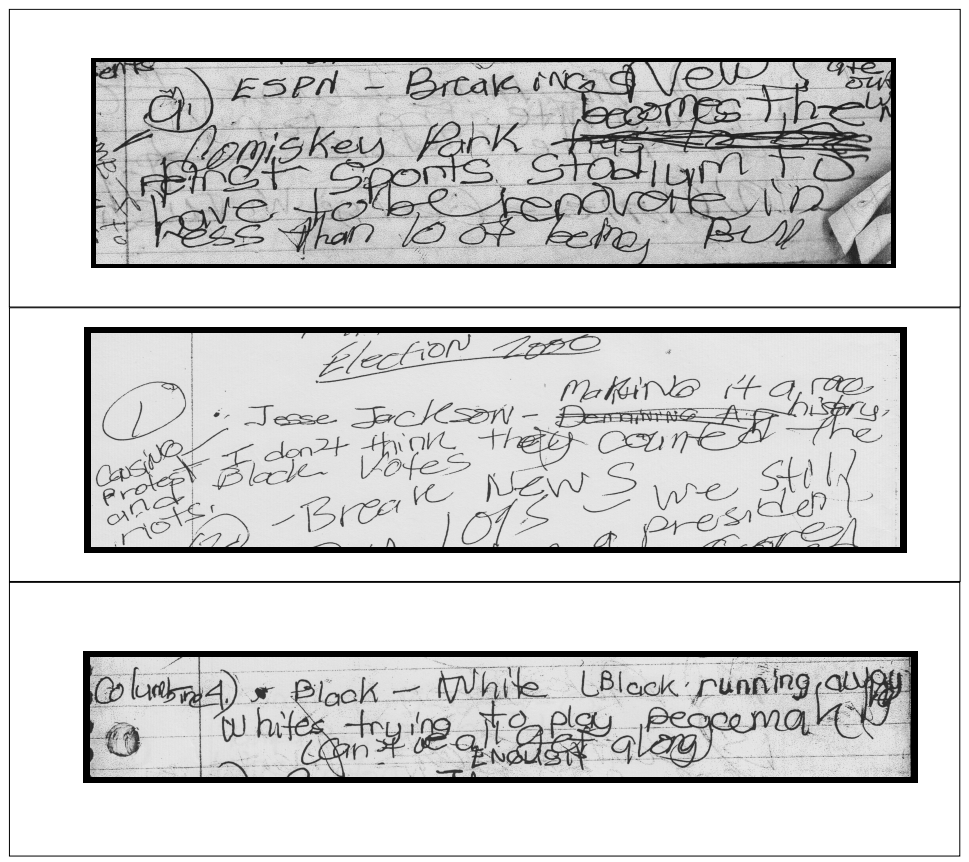

Figure I. Excerpts from Charles's joke notebook

The image at the top of Figure I depicts just one of the many notes from Charles's joke notebook that reference Comiskey Park. Using this note to prompt his memory, Charles would interrupt one of his longer bits by interjecting, "ESPN breaking news, Comiskey Park becomes the first sports stadium to be renovated in less than ten years of being rebuilt" in the voice of Harry Caray or some other sports announcer. During some performances, he would follow this bit with additional quick jabs at the intelligence of the architects behind the park's renovations. At other times, Charles would use his observations of Comiskey Park to move into comments about the Sox's losses, trades, management decisions, and players.

Issues of race also figured largely in Charles's stand-up comedy and provided another fitting topic for pointing out "what's wrong with this picture." For example, as part of a lengthy bit about political figures' responses to the 2000 presidential election results, including those of $\mathrm{Al}$ Gore and George W. Bush, Charles incorporated a smaller bit spoofing Jesse Jackson's charges that the GOP had intimidated Black voters and neglected to count Black votes (the note for which appears in the middle of Figure I). Other bits addressing race frequently took the form of observations about 
differences between social practices of Blacks and Whites (e.g., differences in the parties they throw, the offices of Black and White businesses, etc.), including a short bit about Blacks' and Whites' reactions to the shootings at Columbine High School (the note for which appears at the bottom of Figure I). Charles also occasionally used his own experiences at the university as fodder for his routine. One bit that appeared in many of his shows focused on an experience at the university's required seminar on date rape. Because he showed up a bit late to the session, Charles did not know that the leaders had temporarily separated the male and female students, and he wound up with the females rather than the males. In recounting this experience for his routine, Charles noted his surprise at finding himself as the only male in the group of females, and then stated, "Why am I the only male student who had to attend? Is it because I'm Black?"

\section{Poetry}

Stand-up comedy was not the only self-sponsored literacy in which Charles examined Comiskey Park and issues of race; he also addressed both topics in his poetry. While working at New Expression, a news magazine authored and produced by students attending Chicago-area high schools, Charles and the magazine's poetry editor established The People's Poets Project, with Charles serving as president and editor. By combining their own poems with those they elicited from other Chicago-area teens, Charles and the poetry editor published the Project's first book, titled Days of Our Lives, in August of 1999. After selling two hundred copies of this book, the pair decided to assemble a second one. People's Poets Project: Lasting Impressions, the Project's second collection, was published in July 2000 and sold one hundred and ninety copies.

The topic of sports, and the White Sox in particular, figure prominently in Charles's poetry for this second volume. Poems titled "Nightmare on $35^{\text {th }}$ Street," “Those Were the Days," "Remember," and "Sober Chicago Sports Day, Part Two" all address the White Sox, and several specifically mention Comiskey Park. In his poem "Remember," Charles positions the line "Remember when the Chicago White Sox had fans" amidst a series of other memories, including a time "when Dr. King and Jackie Robinson won the fight." Other poems focus on Comiskey Park in even greater detail. In "Nightmare on $35^{\text {th }}$ Street," Charles examines the relationship between the design of Comiskey Park and the poor attendance at White Sox games, writing, 
Illuminating the Importance of Basic Writers' Self-Sponsored Literacies

I love baseball

But I refuse to fall

I refuse to fall from the top of the ball mall.

I love my White Sox's

But I hate their stupid new park

How can you build something worst than what you're tearing down?

We must stop blaming the upper deck

Because Comiskey is in a wreck

The upper deck is a small part of a larger problem

By offering Comiskey Park as a metaphor for the team, Charles suggests that both have problems that go beyond the surface and that both need to be re-built.

\section{Sports Journalism}

As in his poetry and his stand-up comedy, the White Sox, and Comiskey Park in particular, and issues of race also figured prominently in the columns Charles wrote as the sports editor for New Expression, a position he held throughout his junior and senior years as a high school student. For example, Charles explored the problems with Comiskey Park's upper deck in a column titled "Rebuild the Park and the Fans Will Come," published in New Expression's September I999 issue. In this column, Charles adds his own voice to those connecting the steadily declining numbers of fans attending White Sox games over the past eight years and the current state of Comiskey Park:

I along with many other new Comiskey Park visitors have stories to tell of our nightmare in Comiskey's upper deck. The last time I sat in Comiskey's upper deck, was about a month ago. Man was I hungry, but I was so afraid that I would fall from Comiskey's upper deck that I literally did not move the whole game. [...]

Earlier this year I read a Chicago Sun-Times article called "If You Rebuild It They Will Come." And there has been some talk about the White Sox rebuilding Comiskey Park. [...] No matter if "the kids can play" or not, the fans will not come to an unfriendly ballpark, and Comiskey Park may be the most fan-unfriendly ballpark in the majors today. 
Drawing upon a recently published piece he'd read in the Sun-Times and experiences of Sox fans, including himself, Charles makes a strong case for making changes to Comiskey Park, particularly to the upper deck.

Issues of race were also a fairly prominent topic of Charles's sports journalism. In his column titled "What's Wrong with Sports Today?" Charles voiced a pointed critique of professional baseball's racial inequalities, drawing specifically on his knowledge of baseball history and, in particular, his extensive knowledge of Chicago's professional baseball teams. After opening this piece with a discussion of racism in upper echelons of professional sports, Charles writes,

For years, people of color have fought for the opportunity to play professional sports. Now, they are fighting for the opportunity to coach and own professional teams.

For the first time in Chicago baseball history, both respective managers are people of color. Don Baylor manages the Cubs and Jerry Manuel manages the White Sox. Both are African-American.

Throughout the rest of the article, Charles supports this point with portions of interviews he conducted with members of the White Sox management at the White Sox annual media event.

\section{Laminating Kinesiology 341}

Charles benefited from his stand-up comedy, poems, and sports columns in a number of ways. Clearly, engagement with these self-sponsored literacies gave him a great deal of pleasure. The smile I saw on Charles's face as I watched him perform his stand-up routine in front of the crowds that packed into the student union and his residence hall and when he talked about his published poetry and sports columns during our interviews indicated how much he enjoyed these activities. They also helped Charles develop a base of knowledge about a number of topics of interest to him as an African-American from Chicago's south side and a current member of the university's student body, including, as discussed earlier, the White Sox and their stadium and race relations. ${ }^{4}$ In addition, these self-sponsored literacies also afforded him opportunities to lend his voice quite publicly to conversations about the Sox and their stadium and issues of racism. Finally, his engagement with these literacies also taught Charles something about writing, including a host of practices involved in drafting, revising, 
researching, memorizing, and performing these texts.

In addition, I see these self-sponsored literacies enhancing Charles's second kinesiology essay. In "Intertextualities: Volosinov, Bakhtin, Literary Theory, and Literacy Studies," Charles Bazerman identifies intertextual awareness as a crucial skill for navigating the literate worlds we inhabit. According to Bazerman, the ability to situate a focal text within a rich network of other texts "increases one's agency by planting literate activity in a richer context, increasing one's ability to move around within that context, and helping one deploy parts of it for one's own purposes" (6I-62). Explaining how using intertextuality helps both readers and writers, Bazerman writes,

[d] eveloping a highly articulated picture of the ambient relevant texts can help the writer to define and even redefine the rhetorical situation, position the new text within larger organizations of textual utterances and activities, and bring deeper and richer resources to bear on the current task. Similarly, a highly developed view of the intertextual landscape helps a reader interpret, evaluate, and use a text more effectively. (6I)

Both as readers and writers, a rich, full perspective of intertextual networks helps persons to understand texts more deeply and act with them more effectively. In short, as Bazerman states, "[t]he more broadly and precisely students and other writers envision the intertextual world they can draw on, the more powerful set of flexible options they will have on hand" (63). In this sense, I see the rich intertextual world of Charles's self-sponsored literacies providing him with a powerful set of tools for engaging with Springwood's analysis in his second kinesiology essay.

For Charles as a reader, it seems likely that multiple encounters with Comiskey Park and issues of race across this rich chronotopic network of selfsponsored literacies mediate his engagement with Springwood's discussion. Drawing on Wittgenstein's notion of crisscrossing a landscape as a metaphor for acquiring knowledge, McGinley and Tierney suggest that different forms of writing serve as multiple routes for crossing and re-crossing a topical landscape, widening and enriching students' knowledge of a topic of study through multiple passes from different perspectives. My sense is that Charles's self-sponsored literacies functioned similarly, as traversals across the topic of the White Sox's Comiskey Park and issues of race. Given Charles's rich knowledge of both of these subjects, it is easy to see how Springwood's treatment of baseball stadiums and race relations captured and held his attention. Of 
course, in disposing him toward those topics, this network also attenuated his attention to the many other themes Springwood addressed, including issues of nationhood, family, gender, travel and tourism, democracy, and sexuality. This is not to say that Charles did not mention any of these topics in his second critique, but he certainly did not address them with the same depth as he did the design of ball parks and the sport's racial problems.

I would likewise argue that Charles's self-sponsored literacies also helped him as a writer as he crafted his critique. By foregrounding Comiskey Park and race relations in his essay, Charles could bring the knowledge he had accrued through his stand-up comedy, poetry, and sports columns to bear on Springwood's argument. In addition to the more general knowledge his self-sponsored literacies afforded him regarding baseball and racial issues, it also seems that they might be providing him with specific discourse to employ as well. The observations about problems with Comiskey Park, and with the stadium's upper deck in particular, that Charles employs to extend Springwood's point about ballparks in urban settings seem to index the content and theme of his "Rebuild the Park" story. The information regarding the low numbers of Blacks in management positions that Charles uses to critique Springwood's point about baseball's racial problems seems to index the content and theme of his "What's Wrong with Sports Today" piece. These close similarities suggest that in writing his critique, Charles is drawing upon language that is somewhat "prefabricated" in the sense that he had used it before in his sports columns.

It also seems likely that Charles might be drawing upon some of the other kinds of writing-related knowledge he took from his self-sponsored literacies. In my earlier analysis of Charles's writing for the Rhetoric IoI course he took the semester before, I argued that Charles redeployed literate practices he had developed for crafting news stories as a strategy for engaging with sources in essays for the rhetoric course. The move toward critique, for example, is an important part of Charles's comedy and sports journalism. "The premise for every joke," writes Betsy Borns, "is that something is wrong-with you, with the country, with your mother, with something! If nothing is wrong it's not a joke, it's making conversation" (29). Critique is also an important part of sports journalism. In one of our first interviews on his early experiences reading sports journalism, Charles repeatedly mentioned Jay Mariotti's column in the Chicago Sun-Times. When I asked why he enjoyed Mariotti's pieces, Charles replied, "because of his writing style and because he criticizes everyone, except Michael Jordan." Given the emphasis on critique in Charles's self-sponsored literacies, it seems likely that he might 
draw upon those experiences in critiquing Springwood's comments about Comiskey Park and baseball's racial issues. In essence, this wealth of knowledge gleaned from his self-sponsored literacies allowed Charles to craft his essay as a rhetorical space in which he could speak to Springwood with a voice of an expert rather than a student. As a result, Charles is able to do more than merely summarize the major points of the assigned book. Positioning his second critique in this extensive intertextual network perhaps even allowed Charles to shift the rhetorical context from a response to a class assignment toward a discussion among baseball fans and scholars of the sport, a move which would significantly increase his agency and authority.

In addition to the discourses and texts just mentioned, ${ }^{5}$ Charles's second critique is laminated with a number of other elements from this chronotopic network. Many of the various baseball figures that Charles mentions in his kinesiology essay, including the African-American players, coaches, and managers he references, are mentioned by name in his poems (e.g., Albert Belle and Jackie Robinson) and sports columns (e.g., Don Baylor, Jerry Manuel, Larry Doby, and, again, Jackie Robinson). The same is true of the times, places, and events Charles references in his critique. In addition to mentioning his own embodied experiences watching Sox games from New Comiskey's upper deck and attending Cubs games at Wrigley Field, Charles also points to his experiences attending Sox Fest, the White Sox annual media event, and living in Chicago more broadly. Charles's second critique is also laminated with his physical and emotional reactions to events in his life, including the hunger and the uneasiness he felt while sitting in the upper deck and the racial tensions he experienced at the university and elsewhere.

It also seems possible that these self-sponsored literacies may have enhanced Charles's performance in other aspects of the class. For example, in her comments on Charles's third paper, the professor thanks him for his "excellent contribution to class discussions." Perhaps the discursive practices that afforded Charles a strong voice in Kinesiology 34I, a class that he initially found to be very intimidating, were laminated with those from his stand-up performances as well as his successful performance in Speech IoI. Whether the knowledge from his self-sponsored literacies that helped Charles with his second kinesiology essay was declarative or procedural, or whether it shaped his writing or his reading or both, my sense is that this chronotopic network afforded Charles some degree of what Shannon Carter calls "rhetorical dexterity," the ability to effectively read, understand, and navigate the linguistic and other codes of a new community based on the learner's assessment of a more familiar one (I4). 
Drawing upon the knowledge he gained through his self-sponsored literacies seemed to hold real promise for Charles as he continued to read and write his way through Kinesiology 34I. Perhaps motivated by his professor's comments on the second essay, he again drew upon Comiskey Park in his next critique of Robert Rinehart's Players All: Performances in Contemporary Sport. Addressing Rinehart's point that collecting permanent "markers of experience" of major sporting events has replaced the temporary "experience" itself, Charles listed the many "markers" he'd collected and saved from attending White Sox games, including "scorecards, programs, pictures, and ticket stubs," and elaborated on his favorite features of watching those games in person. This third essay of Charles's earned an even higher grade, and the professor's end comment read, "[a] nice job on the main points. You tie these to interesting first-hand examples-keep up the great work. Thanks also for your excellent contribution to class discussion-It is obvious that you care about class ideas + theories." In addition to awarding significantly higher scores on the second and third assignments, the professor had shifted the emphasis of her end comments from Charles's sentence-level difficulties to the quality of the examples he employed in his critiques and his contributions to class discussions as well. At this point in the course, Charles's anxiety had been replaced by a growing confidence in his ability to engage productively and successfully with the assigned texts. By the end of the semester, Charles had worked his way into an A for his overall course grade, which was based primarily on the scores for his essays.

Over the space of a semester, then, Charles moved from falling short of meeting the literate demands of the course to a level of engagement with the texts and theories that the instructor saw as exemplary. I would argue that many factors informed Charles's improvement. In Kinesiology 34I, Charles certainly encountered a number of the factors that contribute to literate development, including opportunities to write, teacher supportiveness, feedback from teachers and peers, repeat performance opportunities, and whole-class discussion (Rogers 375), and he probably encountered these factors in some of the other courses he was enrolled in that semester as well, including Rhetoric IO2, the second class in the university's basic writing sequence. Importantly, Rogers's list of factors also includes students' preexisting abilities and writing experiences, and I would argue that the writingrelated knowledge Charles acquired through his self-sponsored literacies allowed him, a basic writer by the university's standards, to succeed in the major writing assignments for an upper-division writing-intensive course. Charles did not intend to major in kinesiology, but passing Kinesiology 34I 
allowed him to continue his progress through the undergraduate curriculum and probably bolstered his confidence as a student as well. In addition to making the kinesiology course seem less like an alien world, these kinds of connections were important in other ways as well. Prior and Shipka note that in addition to weaving together literate activities, "chronotopic lamination melds together supposedly separate domains of life" (205). For Charles, these laminations allowed him to weave his personal interests into his academic aspirations of majoring in journalism and pursuing a career as a journalist, thus further thickening and strengthening the alignments between his extracurricular and curricular lives. Perhaps even more importantly, Charles's knowledge of sports and race afforded him the opportunity to weave his school and non-school worlds together, to write himself into the university's curriculum and extracurriculum in ways that let him create and maintain the racial identity he claimed for himself as an African American, which was no small task at a large and predominantly white college.

It is also important to address the profoundly dialogic relationship between Charles's school- and self-sponsored engagements. In many ways, the literate activities of the kinesiology course mediated Charles's engagements with sports outside of the class. For example, in one of his later kinesiology critiques, Charles expressed a desire to visit the famed "Field of Dreams" in Iowa. Referring back to Springwood's point about nostalgia, Charles wrote, "[m]y father resides in Iowa, and I am now strongly considering making the trip to Iowa with my dad during spring break to visit the 'Field of Dreams'. I want to get a first hand look at the site; I want to feel the "Nostalgia'." With spring break just a few weeks away, Charles's statement suggests that his engagement with Springwood's book earlier in the semester is informing his plans for his visit with his father. I don't know if Charles did indeed visit the "Field of Dreams" during spring break. I do know, though, that he continued to write about Comiskey Park in the journalism pieces he wrote following his semester of Kinesiology 34I. In the fall of his sophomore year at the university, Charles's story about the White Sox's upcoming season appeared in that semester's issue of The Orange and Blue Observer, a conservative, libertarian newsletter authored by UIUC students. In that piece, Charles reiterated the many problems with Comiskey Park he'd voiced in his self-sponsored literacies and again in his second essay for kinesiology, and then outlined a number of renovations expected to be completed before the 2002 season. In a sense, it seems that Charles was able to increase his agency when writing for The Orange and Blue Observer by drawing upon his engagement with professional baseball, and the White Sox in particular, 
in Kinesiology 34I. In addition to affording him the opportunity to write publicly about his beloved White Sox and their ballpark, his Observer story also allowed Charles, an African American from Chicago's south side, to reach a new audience. Describing the densely intertextual pathways that connect persons' utterances to spheres of human activity, Mikhail Bakhtin wrote in "The Problem with Speech Genres" that "language enters life through concrete utterances [...] and life enters language through concrete utterances as well" (63). Having traced the complex laminations of Charles's self- and school-sponsored literacies, I sense that together they form part of a rich chronotopic network through which language enters his life and with which he can write his life into his language.

\section{SHIFTING PERSPECTIVES OF BASIC WRITERS' SELF-SPONSORED LITERACIES}

Granted, shifting our perceptions of basic writers and their self-sponsored literacies will certainly not happen overnight. As Min-Zhan Lu, evoking Geneva Smitherman, reminds us, “one cannot erase 'with the stroke of a pen' long-held attitudes and deeply-entrenched biases" ("Composition's Word Work" 206). Still, my hope is that adding this portrait of Charles to those of Maria, Ethel, Joe Baxter, and Jacob will make it easier for us to recognize that the basic writers in our classrooms are part of what Kathleen Yancey refers to as the "writing public" engaged in the writing "taking place largely outside of school" (300; see also Brandt). At the very least, the portraits of these students reinforce the notion that the term "basic writer" only refers to learners' relative inexperience with the kinds of literacies privileged in the academy, and not to their literate lives on the whole (Horner, "Discoursing Basic Writing"; Lu and Horner, Representing). This detailed portrait of Charles can also make it easier for us to recognize the many benefits afforded by selfsponsored literacies. In many ways, the literate activities of comedy stages, poets projects, and sports columns offer Charles the same kinds of benefits that Anne Gere saw accruing from the self-sponsored writing groups that gather in "living rooms, nursing homes, community centers, churches, shelters for the homeless" (76), including "[p]ositive feelings about oneself and one's writing, motivation to revise and improve composition skills, opportunities for publication of various sorts, the belief that writing can make a difference in individual and community life" (78). The fact that certain literate activities are self-sponsored does not diminish their importance for basic writers' development as writers and participants in the world. 
Further, Charles's story pushes us to acknowledge that those benefits include strengthening basic writers' academic engagements. Although they may appear as discrete, autonomous islands of writing, self-sponsored and school-sponsored literacies develop in conjunction with, rather than apart from, one another. Charles's self-sponsored literacies helped him to develop what Rosemary Arca describes as "that sense of potency as a writer who not only has something to say but also has the skills to say it well" (I4I) and in a manner acceptable to the academy. I can imagine that the self-sponsored writing done by Joe, featured in Mutnick's study, and Jacob, from Sternglass's research, benefited their academic writing in a number of ways. In fact, those accounts hint toward these kinds of laminations. Joe's having written a science fiction novel that features a Black main character does seem to inform the school essay he writes about the absence of Blacks in science fiction. Likewise, Jacob's reflections on his own stylistic choices in writing countless poems, short stories, and a short novel seem to inform the critique of Thomas Kuhn's writing style he included in a paper on The Structure of Scientific Revolutions for a world civilization class.

My sense is that recognizing the importance of basic writers' selfsponsored literacies could impact our research in important ways. This portrait of the far-flung network of literate activities laminating Charles's engagement with kinesiology suggests the need to adopt theoretical and methodological frameworks that can make visible the historical trajectories of discourse, people, places, practices, and artifacts as they are repurposed across what might appear to be unrelated and temporally and spatially distant activities. Without such frameworks, researchers might assume that the literacy event witnessed in the here and now is all that needs to be studied, or that the material inscriptions animating the present activity are all that need to be collected and examined. Lacking such a perspective, an examination of Charles's successes with kinesiology might remain situated comfortably within the privileged temporal and spatial boundaries of that university course, or perhaps school more broadly, without attending to other aspects of his literate life. Our theories and methods also need to address the transformations across representational media that can occur throughout such networks. Lacking those, researchers stand to overlook the semiotic pathway of Charles's comedy bits as they are initially entextualized and revised in his joke book; then memorized; then voiced and performed during his stand-up routines; and then re-entextualized as they are written into his kinesiology essays. As a way of broadening our attention beyond basic writers' self-sponsored short stories, novels, and the other texts most 
commonly associated with creative writing, the theories and methods we employ to examine the self-sponsored literate networks students assemble also need to address more fully the kinds of "minor texts" (249), including lists, notes, and labels, that Stephen Witte examined, as well as the broader range of communicative tools Vygotsky pointed to, including "various systems for counting; mnemonic techniques; algebraic symbol systems; works of art; writing; schemes; diagrams; maps; and mechanical drawings" (I37). In making visible the wide range of elements that flow into and emanate from literate activities, such theories and methods can contribute to the development of models of writing that more fully represent the richness of students' literate lives and the complexity of how they navigate textual worlds.

Viewing students' self-sponsored literate activities as key resources that inform their school writing could help encourage basic writing research to contribute to the growing body of scholarship in composition studies addressing issues of "writing transfer" (Beaufort; Bergmann and Zepernick; Nowacek; Reiff and Bawarshi; Smit; Rounsaville; Wardle). In The End of Composition Studies, David Smit asserts that beyond the basic knowledge that persons do splice together seemingly diverse literate activities, there may be little more we can say about the horizontal nature of our students' growth as writers (132). And yet, Charles's case suggests that a great deal remains to be said, that we're only beginning to explore, theorize, understand, and discuss the various kinds of activities basic writers are engaged in, their influence on each other, and the connections forged between them. Increased attention to self-sponsored literacies would also invite us to examine the sites that sponsor their development. In Words at Work and Play: Three Decades in Family and Community Life, Shirley Brice Heath predicts that "learning that lies outside formal instruction and designated experts" will play an increasingly important role in how persons develop skills and knowledge (I70). "This kind of learning," Heath writes, "remains invisible to most adults; however, society will increasingly value the informal learning that comes through special interests, peer relationships, and mentors who inspire young people to play roles beyond those of child or student and to take on increasing levels of responsibility" (I7I). Heath's prediction suggests that we need to know more, much more, about creating, maintaining, and enhancing organizations such as New Expression, the student publication that fostered Charles's engagement with sports journalism and poetry, and the university's Open Mic Night, the space that sponsored Charles's standup comedy. We also need to actively investigate the kinds of identities and responsibilities such literacy spaces occasion. In addition to helping us more 
readily recognize those spaces as vital to fostering a writing public, understanding them can also reveal how we might forge and maintain productive connections between those sites and our classrooms.

Richer, more robust conceptions of basic writers' self-sponsored writing could also prompt a shift in our teaching. In "The Idea of Expertise: An Exploration of Cognitive and Social Dimensions of Writing," Michael Carter writes that " $[\mathrm{w}]$ hat we do in our writing classrooms is determined, implicitly or explicitly, by our concepts of what it means to be an expert writer and how writers attain expertise" (280). Adopting the perspective that self-sponsored literacies are a key means through which basic writers might gain expertise, not just in first-year composition classes but also throughout the undergraduate curriculum, should prompt teachers to make those literacies part of their classrooms and curricula. One approach might involve raising the issue of self-sponsored literacies with the students themselves by having them examine the purposes and functions such literacies serve and the kinds of practices they demand. In this sense, self-sponsored literacies become the focus of the kinds of analytic writing students learn to do in the core curriculum classes as well as their majors. Pedagogically, this move seems like a logical extension of asking students to engage with the literacy narratives of Richard Rodriguez, Victor Villanueva, Fan Shen, and Malcolm X, but with a focus on the students themselves and their own textual engagements. We might begin by asking students to examine the roles that self-sponsored literacies play in the lives of Joe Baxter and Jacob, for example, and then, in turn, ask them to examine the roles that self-sponsored literacies play in their own lives. We might, for example, take up Beverly Moss's invitation to have students examine what they have learned about literacy from their religious engagements and to analyze the "points of common ground" and "points of conflict" (Moss I37) with their academic activities. If, as Bazerman argues, writers benefit from configuring the intertextual world as broadly as possible, then we should work toward developing curricula that help them do so. At the very least, we want curricula that help students to see that the relevance of a text or literate activity should not be determined by whether or not it was assigned by a teacher.

In designing a curriculum that includes basic writers' self-sponsored engagements with reading and writing, though, we need to be careful to do so in a manner that does not suggest that they are merely some sort of "crutch" that students should use only until they feel more comfortable with the kinds of literacies privileged in the academy. The lamination of academic and self-sponsored literacies is not the equivalent of a kind of "training wheel" 
which eventually needs to be taken off so that learners can do the "real" textual work of their chosen disciplines and professions. Studies of learners at a variety of points throughout their lives and at a number of educational levels, including students in elementary school (Dyson; Pahl, "Timescales and Ethnography," "Texts as Artefacts"), middle school (Finders; Shuman), and high school (Smith and Wilhelm); in first-year composition and other introductory undergraduate courses (Fishman, Lunsford, McGregor, and Otuteye; Reiff and Bawarshi; Roozen, "From Journals to Journalism"; Roozen and Herrera, "Indigenous Interests"); in upper-division undergraduate courses (Roozen, “The 'Poetry Slam,' Mathemagicians, and Middle-School Math"; Russell and Yañez); in MA and PhD programs (Prior and Shipka; Roozen, “Tracing Trajectories of Practice," “Fan Fic-ing' English Studies”); and working professionals (Prior and Shipka; Roozen, "Seeing the Whole Patient"), indicate that the weaving together of multiple literate engagements is a key element of literate development throughout the lifespan. ${ }^{6}$

Describing all that the lamination of literate activity encompasses, Prior and Shipka write, "[i]t is especially about the ways we not only come to inhabit made-worlds, but constantly make our worlds-the ways we select from, (re)structure, fiddle with, and transfrom the material and social worlds we inhabit" (I82). Ultimately, our portraits of Maria, Ethel, Joe Baxter, Jacob, and Charles Scott, Jr., speak powerfully to the important roles that self-sponsored literacies can play in helping basic writers inhabit, remake, reconfigure, even productively disrupt, the densely textual landscapes they traverse throughout the undergraduate curriculum and, more importantly, throughout their lives. Those landscapes are populated with the literacies of students' homes, neighborhoods, and communities just as much as they are with the literacies of their disciplines and professions; of stand-up routines, poets projects, and sports journalism just as much as of school and work.

\section{Acknowledgments}

I would like to thank Charles Scott, Jr., for teaching me so much about his richly literate life and what it means to understand students as already possessing rich histories with literacy; the editors and reviewers for the Journal of Basic Writing, who provided me with a wealth of suggestions and encouragement that pushed my thinking; and my colleague and friend Steve Lamos, who helped me craft an early conference talk based on this data and commented on several early versions of this article. I also want to thank Rebecca Mlynarczyk, Deborah Mutnick, and Shannon Carter, who have 
encouraged me to keep examining basic writers' self-sponsored literacies and the organizations that foster them. Finally, I need to thank Elizabeth Wardle, Mark Hall, Angela Rounsaville, and Stacey Pigg for a week's worth of conversations that helped me rethink the relationship between literate activities.

\section{Notes}

I. Charles granted permission for his real name to be used when he volunteered to participate in this research in September of 2000 . He continued to grant permission to do so each year we continued this project and after reading drafts of the many conference presentations and the dissertation chapter that emerged from this research.

2. Kinesiology is a field of study devoted to human movement and performance related to health and physical education, physical and occupational therapy, and sport and exercise. As a field, kinesiology is informed by sciences including anatomy, physiology, and biomechanics, but it also has a strong sociological and ethnographic component, particularly regarding the cultural function of sports and leisure activities in cultural settings. The course that Charles took, Kinesiology 34I: Games in Culture, focused on the sociological aspects of kinesiology.

3. Throughout this article, I present excerpts from Charles's writing exactly as written, recognizing that they frequently include unconventional grammar, spelling, and punctuation.

4. Self-sponsored activities such as Charles's stand-up comedy routines and the various texts associated with them may seem so mundane as to be fairly unimportant. However, consider the opening of Mary Louise Pratt's "Arts of the Contact Zone" in which she reflects on all that her son Sam learned from his engagement with baseball cards: "Sam and Willie learned a lot about phonics that year by trying to decipher surnames on baseball cards, and a lot about cities, states, heights, weights, places of birth, stages of life. In the years that followed, I watched Sam apply his arithmetic skills to working out batting averages and subtracting retirement years from rookie years; I watched him develop senses of patterning and order by arranging and rearranging his cards for hours on end, and aesthetic judgment by comparing different 
photos, different series, layouts, and color schemes. American geography and history took shape in his mind through baseball cards. Much of his social life revolved around trading them, and he learned about exchange, fairness, trust, the importance of process as opposed to results, what it means to get cheated, taken advantage of, even robbed. Baseball cards were the medium of his economic life too. Nowhere better to learn the power and arbitrariness of money, the absolute divorce between use value and exchange value, notions of long- and short-term investment, the possibility of personal values that are independent of market values" (5I7). My sense is that, as with Pratt's son, Charles's self-sponsored literacies provide one avenue for him to examine topics including racism, geography, economics, history, and so on.

5. I do not wish to suggest that the intertextual network informing Charles's second critique is limited to only the self-sponsored texts and activities detailed in this article. Rather, it reaches deep into many of the other literate activities Charles talked about during our interviews. Some of his early encounters with professional sports, for example, came through reading about the exploits of his favorite teams in the sports sections of newspapers like the Chicago Tribune, the Chicago Sun-Times, and the Chicago Defender. One early memory involved his great-aunt and -uncle reading the newspaper at the kitchen table each morning, with Charles waiting rather impatiently for them to hand him the sports page so he could check the baseball scores and read what the local sports columnists had to say about the Cubs and the White Sox. Another of his earliest sports-related memories involved reading and memorizing the statistics on the backs of the baseball cards he collected so that he could impersonate for his family and friends the baseball announcers who were calling televised baseball games. He also recalled reading the information on tickets, programs, and other memorabilia he collected from the games he attended. Later, when he had access to a computer, he read the sports pages online, a practice that he continued on a daily basis throughout high school and college.

6. In his author's note to a chapter of An Open Language, Mike Rose describes the importance of these kinds of laminations to the writing he did during his doctoral studies and then later still as he wrote Lives on the Boundary: "For some time before I began my doctoral studies in education, I had been writing poetry. Much of it, especially the early stuff, wasn't all that good, but it brought me such pleasure, hiding away a few afternoons each week, unplugging the phone, and getting lost in writing. [...] One thing I did was 
to photocopy a few paragraphs on the structure of long-term memory from a cognitive psychology textbook and tape them on a large sheet of paper. Underneath them, I placed some lines of poetry I had written about events from my childhood: a discussion of memorial processes right next to a description of memories. [...] It was this sort of fooling around with text and genre that would lead to the form of Lives on the Boundary. Over the next few months, I would shift from poetry to narrative vignette-about my own education and that of others as well-and in place of the textbook passages, there would be analysis of the kind I was writing for scholarly journals" (287-88). Rose's description suggests that the laminating of multiple discourses and literate activities Charles engages in is an essential part of literate development throughout the lifespan and not a practice employed only by entering college students to write their way into the university.

\section{Works Cited}

Adler-Kassner, Linda. "Digging a Groundwork for Writing: Underprepared Students and Community Service Courses." College Composition and Communication 46.4 (I995): 552-55. Print.

Arca, Rosemary. "Systems Thinking, Symbiosis, and Service: The Road to Authority." Writing the Community: Concepts and Models for ServiceLearning in Composition. Ed. Linda Adler-Kassner, Robert Cooks, and Ann Watters. Washington D.C.: American Association for Higher Education, I997. I33-4I. Print.

Bakhtin, Mikhail. Speech Genres and Other Late Essays. Ed. Cary Emerson and Michael Holquist. Trans. Vern McGee. Austin: University of Texas P, I986. Print.

Bazerman, Charles. "Intertextualities: Volosinov, Literary Theory, and Literacy Studies." Bakhtinian Perspectives on Languages, Literacy, and Learning. Ed. Arnetha Ball and Sarah W. Freedman. Cambridge, UK: Cambridge UP, 2004. 53-65. Print.

Beaufort, Anne. College Writing and Beyond: A New Framework for University

Writing Instruction. Logan, UT: Utah State UP, 2007. Print.

Bergmann, Linda, and Janet Zepernick. "Disciplinarity and Transference:

Students' Perceptions of Learning to Write." WPA Journal 3I.I/2 (2007): I24-49. Print.

Borns, Betsy. Comic Lives: Inside the World of American Stand-up Comedy.

New York: Simon and Schuster, I987. Print.

Brandt, Deborah. "Writing Over Reading: New Directions in Mass Lit- 
eracy." The Future of Literacy Studies. Ed. Mike Baynham and Mastin Prinsloo. New York: Palgrave, 2009. 54-74. Print.

Canagarajah, A. Suresh. "Toward a Rhetoric of Translingual Writing." Paper \# I. Working Papers on Negotiating Language and Literacy: Practices and Pedagogies. 2012. Web.

Carter, Michael. "The Idea of Expertise: An Exploration of Cognitive and Social Dimensions of Writing." College Composition and Communication 4I.3 (I990): 265-86. Print.

Carter, Shannon. The Way Literacy Lives: Rhetorical Dexterity and Basic Writing Instruction. Albany, NY: SUNY Press, 2008. Print.

Courage, Richard. "The Interaction of Public and Private Literacies." College Composition and Communication 44.4 (I993): 484-96. Print.

Dyson, Ann Haas. The Brothers and Sisters Learn to Write: Popular Literacies in Childhood and School Cultures. Columbia, IL: Teachers College Press, 2003. Print.

Finders, Margaret. Just Girls: Hidden Literacies and Life in Junior High. New York and Urbana, IL: Teachers College Press, I997. Print.

Fishman, Jenn, Andrea Lunsford, Beth McGregor, and Mark Otuteye. "Performing Writing, Performing Literacy." College Composition and Communication 57.2 (2005): 224-52. Print.

Gabor, Catherine. "Writing Partners: Service Learning as a Route to Authority for Basic Writers." Journal of Basic Writing 28.I (2009): 50-70. Print.

Gere, Ann Ruggles. “Kitchen Tables and Rented Rooms: Composition's Extracurriculum." College Composition and Communication 45.I (I994): 75-92. Print.

Gilyard, Keith. Voices of the Self: A Study of Language Competence. Detroit, MI: Wayne State UP, I99I. Print.

Heath, Shirley Brice. Words at Work and Play: Three Decades in Family and Community Life. New York: Cambridge UP, 20I2. Print.

Horner, Bruce. "Discoursing Basic Writing." College Composition and Communication 47.2 (I996): I99-222. Print.

---. "Relocating Basic Writing." Journal of Basic Writing 30.2 (20II): 50-68. Print.

Horner, Bruce, Min-Zhan Lu, Jacqueline Jones Royster, and John Trimbur. "Language Difference in Writing: Toward a Translingual Approach." College English 73.3 (2OII): 303-2I. Print.

Hull, Glynda, and Mike Rose. “ 'This Wooden Shack Place': The Logic of an Unconventional Reading." College Composition and Communication 
Illuminating the Importance of Basic Writers' Self-Sponsored Literacies 4I.3 (I990): 287-98. Print.

Hull, Glynda, Mike Rose, Kay Fraser, and Maria Castellano. "Remediation as Social Construct: Perspectives from an Analysis of Classroom Discourse." College Composition and Communication 42.3 (I99I): 299-3I9. Print.

Lu, Min-Zhan. “Composition's Word Work: Deliberating How to Do Language." Composition Studies in the New Millennium: Rereading the Past, Rewriting the Future. Ed. Lynn Z. Bloom, Donald Daiker, and Edward M. White. Carbondale, IL: Southern Illinois UP, 2003. I93-207. Print. ---. "From Silence to Words: Writing as Struggle." College English 49.4 (I987): 437-48. Print.

Lu, Min-Zhan, and Bruce Horner. Representing the Other: Basic Writers and the Teaching of Basic Writing. Urbana, IL: National Council of Teachers of English, I999. Print.

---. “Translingual Literacy and Matters of Agency." Paper No. 2. Working Papers on Negotiating Language and Literacy: Practices and Pedagogies. 2OI2. Web. 3 Sept. 2012.

McCrary, Donald. “Represent, Representin', Representation: The Efficacy of Hybrid Texts in the Writing Classroom." Journal of Basic Writing 24.2 (2005): 72-9I. Print.

McGinley, William, and Robert J. Tierney. "Traversing the Topical Landscape: Reading and Writing as Ways of Knowing." Written Communication 6.3 (I989): 243-69. Print.

Moss, Beverly. A Community Text Arises: A Literate Text and a Literacy Tradition in African-American Churches. New York: Hampton Press, 2002. Print.

Mutnick, Deborah. Writing in an Alien World: Basic Writing and the Struggle for Equality in Higher Education. Portsmouth, NH: Boyton/Cook, I996. Print.

Nowacek, Rebecca. Agents of Integration: Understanding Transfer as Rhetorical Act. Carbondale, IL: Southern Illinois UP, 2OII. Print.

Pahl, Kate. “Timescales and Ethnography: Understanding a Child's Meaning-making Across Three Sites, a Home, a Classroom, and a Family Literacy Class." Ethnography and Education 2.2 (2007): I75-90. Print. ---. "Texts as Artefacts Crossing Sites: Map Making at Home and School." Reading: Literacy and Language 35.3 (200I): I2O-25. Print.

Pine, Nancy. "Service Learning in a Basic Writing Class: A Best Case Scenario." Journal of Basic Writing 27.2 (2008): 29-55. Print.

Pratt, Mary Louise. "Arts of the Contact Zone." Ways of Reading: An Anthol- 
ogy for Writers. 7 th ed. Ed. David Bartholomae and Anthony Petrosky. Boston: Bedford/St. Martins, 2005. 517-30. Print.

Prior, Paul, and Jody Shipka. "Chronotopic Lamination: Tracing the Contours of Literate Activity." Writing Selves, Writing Societies. Ed. Charles Bazerman and David Russell. Fort Collins, CO: The WAC Clearinghouse, 2003. I80-238. Web. I5 April 2012.

Reiff, Mary Jo, and Anis Bawarshi. "Tracing Discursive Resources: How Students Use Prior Genre Knowledge to Negotiate New Writing Contexts in First-Year Composition." Written Communication 28.3 (20II): 3I2-37. Print.

Rinehart, Robert. Players All: Performances in Contemporary Sport. Bloomington, IN: Indiana UP, I998. Print.

Rodriguez, Richard. Hunger of Memory: The Education of Richard Rodriguez. New York: Bantam, 1982. Print.

Rogers, Paul. "The Contributions of North American Longitudinal Studies of Writing in Higher Education to Our Understanding of Writing Development." Traditions of Writing Research. Ed. Charles Bazerman, Robert Krut, Karen Lunsford, Susan McLeod, Suzie Null, Paul Rogers, and Amanda Stansell. New York: Routledge, 20IO. 365-77. Print.

Roozen, Kevin. "'Fan Fic-ing' English Studies: A Case Study Exploring the Interplay of Vernacular Literacies and Disciplinary Engagement." Research in the Teaching of English 44.2 (2009): 136-69. Print.

---. "From Journals to Journalism: Tracing Trajectories of Literate Development." College Composition and Communication 60.3 (2009): 54I-72. Print.

---. "Journalism, Poetry, Stand-Up Comedy, and Academic Literacy: Mapping the Interplay of Curricular and Extracurricular Literate Activities." Journal of Basic Writing 27.I (2008): 5-34. Print.

---. "Seeing the Whole Patient: Acting Inventively at the Intersections of Multiple Discursive Practices and Inscriptional Tools." Paper delivered at the Conference on College Composition and Communication. Atlanta. 7 April 201 or.

---. "The 'Poetry Slam,' Mathemagicians, and Middle-School Math: Tracing Trajectories of Actors and Artifacts." Exploring Semiotic Remediation as Discourse Practice. Ed. Paul Prior and Julie Hengst. New York: Palgrave, 20IO. 24-5I. Print.

---. "Tracing Trajectories of Practice: Repurposing in one Student's Developing Disciplinary Writing Processes." Written Communication 27.3 (2OIO): 318-54. Print. 
Illuminating the Importance of Basic Writers' Self-Sponsored Literacies

Roozen, Kevin, and Angelica Herrera. “'Indigenous Interests': Reconciling Literate Identities across Extracurricular and Curricular Contexts." Inventing Identities in Second Language Writing. Ed. Michelle Cox, Jay Jordan, Christina Ortmeier-Hooper, and Gwen Gray Schwartz. Urbana, IL: NCTE, 20IO. I39-62. Print.

Rounsaville, Angela. "Selecting Genres for Transfer: The Role of Uptake in Students' Antecedent Genre Knowledge." Composition Forum 26 (2OI2). Web. 22 Sept. 2012.

Rose, Mike. An Open Language: Selected Writings on Literacy, Learning, and Opportunity. Boston: Bedford/St. Martin's, 2006. Print.

---. Lives on the Boundary. New York: Penguin Books, I989. Print.

Russell, David, and Arturo Yañez. “'Big Picture People Rarely Become Historians': Genre Systems and the Contradictions of General Education." Writing Selves, Writing Societies. Ed. Charles Bazerman and David Russell. Fort Collins, CO: The WAC Clearinghouse, 2003. 33I-62. Web. I8 Aug. 2008.

Scollon, Ron. Mediated Discourse: The Nexus of Practice. New York: Routledge, 200I. Print.

Scott, Charles, Jr. “Nightmare on 35th Street." The People's Poets Project:

Lasting Impression. Chicago, IL: PP Publication, 2000. I7. Print.

---. "Rebuild the Park and the Fans Will Come." New Expression 22 (September I999): II. Print.

---. "Remember." The People's Poets Project: Lasting Impression. Chicago: PP Publication, 2000. 19. Print.

---. "What's Wrong with Sports Today?" New Expression 23 (April 2000): I6. Print.

---. "White Sox Reach Crossroads." The Orange and Blue Observer II (November 200I): 9, I9. Print.

---. "Winning Teams, Losing Fans." New Expression 24 (May 2000): 9. Print. Shaughnessy, Mina P. "Diving In: An Introduction to Basic Writing." College Composition and Communication 27.3 (I976): 234-39. Print.

---. Errors and Expectations: A Guide for the Teacher of Basic Writing. New York: Oxford UP, 1977. Print.

Shen, Fan. "The Classroom and the Wider Culture: Identity as a Key to Learning English Composition." College Composition and Communication 40.4 (I989): 459-66. Print.

Shuman, Amy. Storytelling Rights: The Uses of Oral and Written Texts by Urban Adolescents. Cambridge, UK: Cambridge UP, I986. Print.

Smit, David. The End of Composition Studies. Carbondale, IL: Southern Il- 
linois UP, 2004. Print.

Smith, Michael, and Jeffrey Wilhelm. Reading Don't Fix No Chevys: Literacy in the Lives of Young Men. New York: Boynton/Cook, 2002. Print.

Smitherman, Geneva. Talkin and Testifyin: The Language of Black America. Detroit, MI: Wayne State UP, I986. Print.

Springwood, Charles. Cooperstown to Dyersville: A Geography of Baseball Nostalgia. Boulder, CO: Westview Press, I996. Print.

Sternglass, Marilyn. Time to Know Them: A Longitudinal Study of Writing and Learning at the College Level. Mahwah, NJ: Erlbaum, I997. Print.

Suits, Bernard. The Grasshopper: Games, Life, and Utopia. Toronto: University of Toronto P, I978. Print.

Villanueva, Victor. Bootstraps: From an American Academic of Color. Urbana, IL: NCTE, I993. Print.

Vygotsky, Lev Seminovich. Mind in Society: The Development of Higher Psychological Processes. Ed. Michael Cole, Vera John-Steiner, Sylvia Scribner, and Ellen Souberman. Cambridge, MA: Harvard UP, I979. Print.

Wardle, Elizabeth. “Understanding 'Transfer' from FYC: Preliminary Results of a Longitudinal Study." WPA Journal 3I.I/2 (2007): I24-49. Print.

Witte, Stephen. “Text, Context, Intertext: Toward a Constructivist Semiotic." Written Communication 9.2 (I992): 237-308. Print.

Wittgenstein, Ludwig. Philosophical Investigations. New York: Macmillan, I953. Print.

X, Malcolm, with Alex Haley. The Autobiography of Malcolm X. New York: Grove Press, I965. Print.

Yancey, Kathleen. "Made Not Only in Words: Composition in a New Key." College Composition and Communication 56.2 (2004): 297-328. Print. 


\section{News and Announcements}

\section{A Set of the Journal of Basic Writing for Scholars' Use}

Recently, Barbara Kroll, Professor Emerita of California State UniversityNorthridge, donated a nearly complete set (from I975 to I996) of Journal of Basic Writing issues to the journal's editors in the hope that they could be used by scholars in the field. We would like to see these journals housed in the library of a university with a vital composition and rhetoric program that includes a focus on basic writing and which currently does not own a print set. We will add the missing issues to the set.

Please contact JBW's editors, Hope Parisi (hopekcc@aol.com) or Cheryl C. Smith (cheryl.smith@baruch.cuny.edu), with the name of a potential library home for these issues. Also please include the name, email, and phone of a library contact person.

Thank you to Professor Barbara Kroll!

\section{Call for Proposals-20I3 Graduate Research Network}

The Graduate Research Network (GRN) invites proposals for its 2013 workshop on June 6, 20I3, at the Computers and Writing Conference hosted by Frostburg University, Frostburg, MD. The C\&W Graduate Research Network is an all-day pre-conference event, open to all registered conference participants at no charge. Roundtable discussions group those with similar interests and discussion leaders who facilitate discussion and offer suggestions for developing research projects and for finding suitable venues for publication. We encourage anyone interested or involved in graduate education and scholarship-students, professors, mentors, and interested others-to participate in this important event. The GRN welcomes those pursuing work at any stage, from those just beginning to consider ideas to those whose projects are ready to pursue publication. Participants are also invited to apply for travel funding through the CW/GRN Travel Grant Fund. Deadline for submissions is May 9, 20I3. For more information or to submit a proposal, visit our Web site at http://www.gradresearchnetwork.org or email Janice Walker at jwalker@georgiasouthern.edu. 


\section{Call for Proposals and Invitation to Register-Fifth Annual Con- ference on Acceleration in Developmental Education}

The Community College of Baltimore County will be hosting the Fifth Annual Conference on Acceleration in Developmental Education on June I2-I4, 2013 in Baltimore, MD. Workshops in Integrated Reading and Writing, the Accelerated Learning Program, Faculty Development for ALP, and Accelerated Math will be held on June I2. June I3-I4 will feature breakout sessions on all aspects of acceleration. Session proposals are due by March 23, 2013 .

Proposals and Registration can be accessed at: http://alp-deved.org/category/ alp-conference-20I3/

\section{Invitation to Register-Conference on Basic Writing (CBW) Work- shop at the Conference of College Composition and Communica- tion, Las Vegas, 2013}

The annual CBW workshop at CCCC will be held on Wednesday, March I3, 20I3. This year's workshop-Basic Writing and Race: A Symposiumfeatures a keynote address by Victor Villanueva, "Toward a Political Economy of Basic Writing Programs"; a roundtable discussion, "Race, Language, and Access," with Scott Lyons, Beatrice Mendez-Newman, Min-Zhan Lu, and Shirley Faulker-Springfield, moderated by Steve Lamos and Wendy Olsen; and additional sessions on race and the public work of basic writing, publishing and grant writing, and professional and social networking.

Also join us for the CBW Special Interest Group (SIG) TSGI.04 on March I5, 20I3 from 6:30-7:30 pm.

Many Basic Writing sessions at CCCC will be live blogged on http://cbwblog. wordpress.com

\section{Call for Proposals—BWe Special Issue}

Theme: Basic Writing and Community Engagement

Guest Editor: Tom Peele, Associate Professor, Long Island University, Brooklyn 
How does community engagement serve basic writers, and how do basic writers participate in their communities?

Research from across the discipline of rhetoric and composition demonstrates that a wide variety of students-English language learners, basic writing, mainstream, and honors-have the potential to benefit from community-based writing. Scholars note that students benefit from exposure to a wide range of rhetorical situations and the felt sense that writing addressed to an audience outside the classroom often seems more immediate and more personal than traditional classroom writing. Writing that stems from community engagement also has the potential to increase students' sense of agency.

For the Spring 20I4 issue of $B W e$, we seek articles that investigate the uses and effects of community engagement in basic writing coursework. Our concept of "community engagement" is conceived very broadly, and includes concepts covered by umbrella terms such as service-learning, community based learning, and community literacy. In addition, we're interested in interdisciplinary collaborations from any perspective. How has your basic writing course worked with the library, the writing center, or other disciplines? We welcome submissions not only from basic writing faculty, but also faculty from other disciplines or from community partners who have collaborated with basic writing classes.

Article submissions will be accepted through July I5, 20I3. BWe submissions will be responded to no later than September I5, 20I3. If revision is requested, a final revision from a $B W e$ author must be submitted by January 5,2014 .

$B W e$ is a peer-reviewed online journal that welcomes both traditional and multi-modal texts. Submission guidelines for formatting print essays and webtexts appear on the $B W e$ Web site: http://bwe.ccny.cuny.edu/. Please direct submissions and further questions to Tom Peele (Thomas.Peele@liu. edu). 
How is this publication thinking about the future?

By becoming part of the past.

This publication is available from

ProQuest Information and Learning

in one or more of the following ways:

- Online, via the ProQuest*

information service

- Microform

- CD-ROM

- Via database licensing

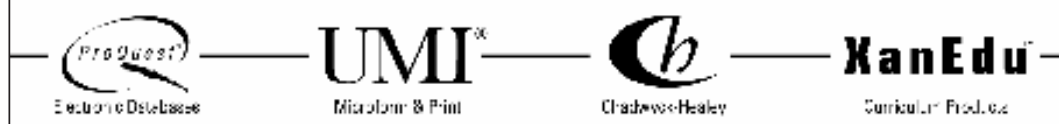

Fir arrse inforrration, rall

I-800-52I-0600, cxt. 2888 (US) ur oI-734-76I-4700 (Internatsond)

swaw.il.procpuest.rom

From:ProCuest 


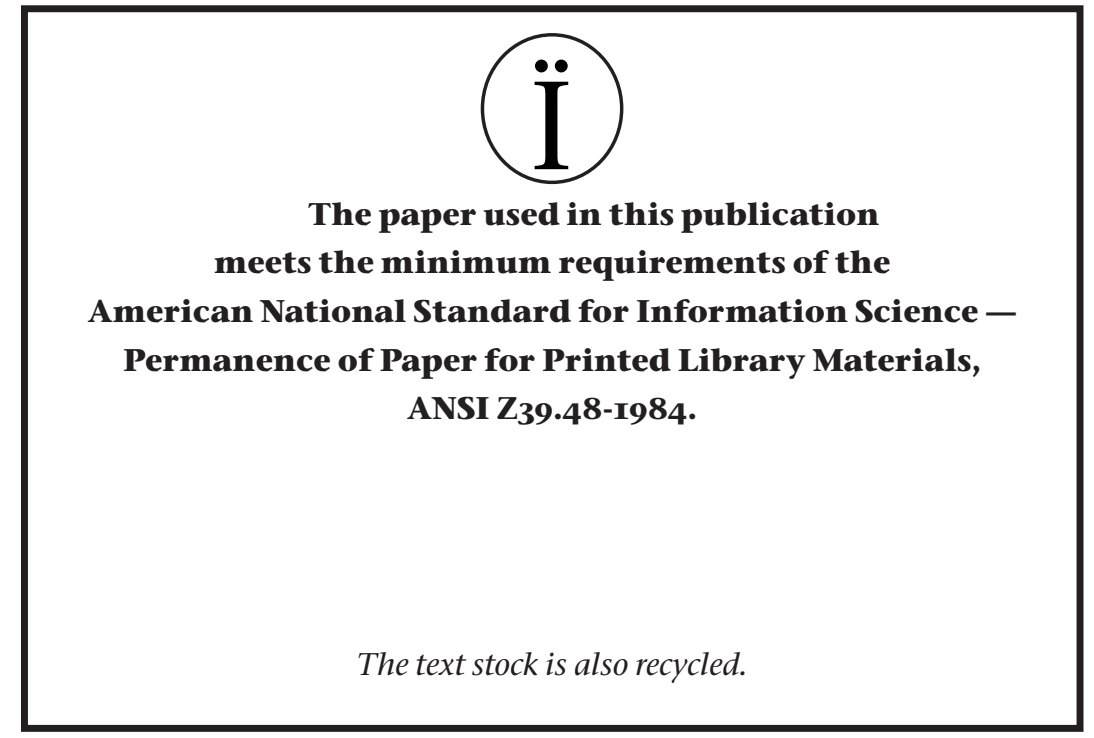




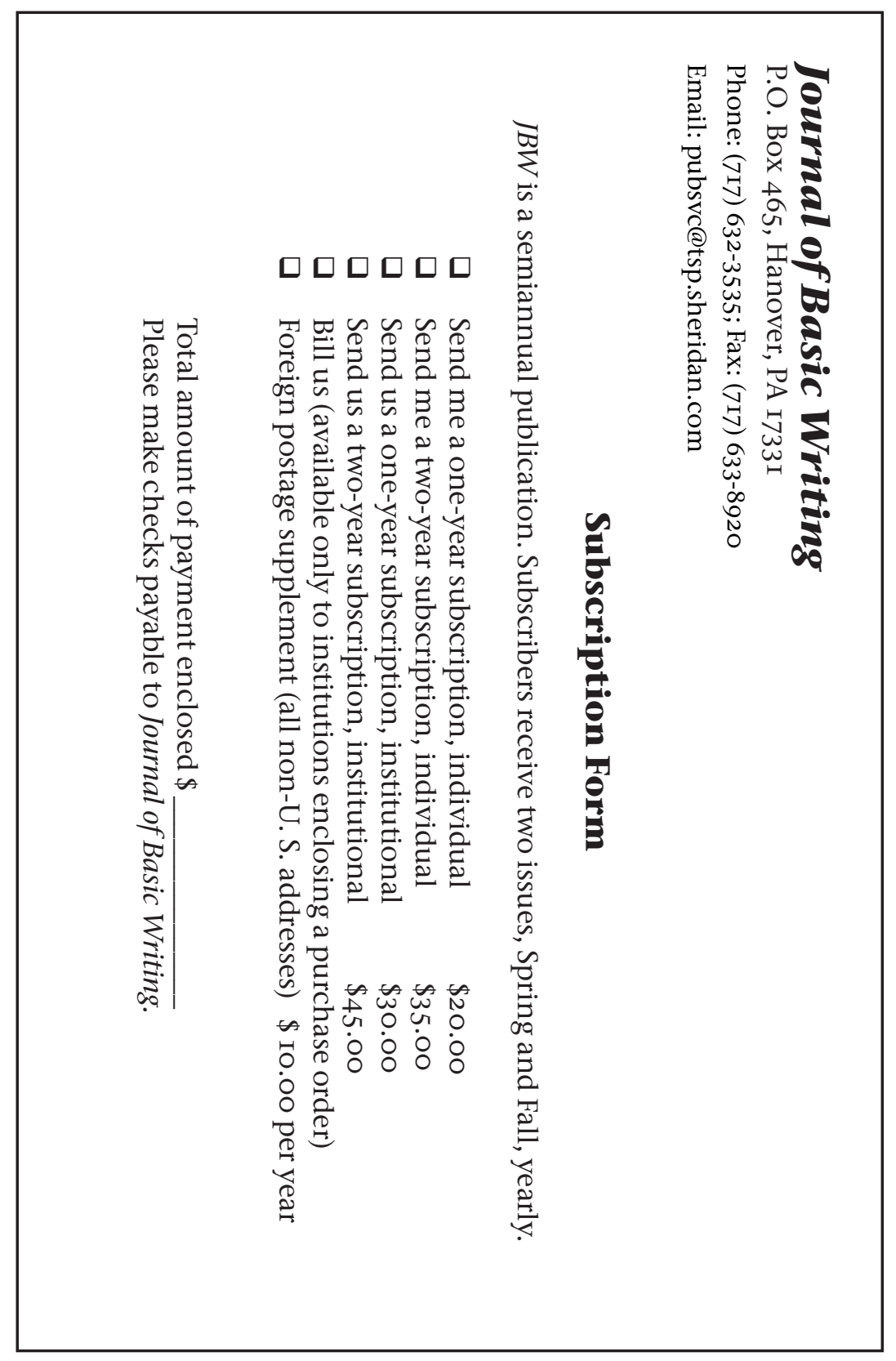




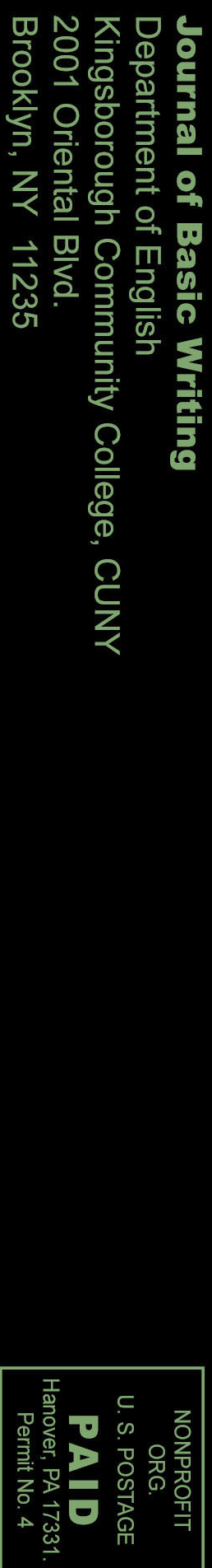